\title{
Narratives of Fracture: Class and Gender in Irish and Indian Postcolonial Domestic Fiction
}

\author{
Sreya Chatterjee
}

Follow this and additional works at: https://researchrepository.wvu.edu/etd

\section{Recommended Citation}

Chatterjee, Sreya, "Narratives of Fracture: Class and Gender in Irish and Indian Postcolonial Domestic Fiction" (2017). Graduate Theses, Dissertations, and Problem Reports. 5337.

https://researchrepository.wvu.edu/etd/5337

This Dissertation is protected by copyright and/or related rights. It has been brought to you by the The Research Repository @ WVU with permission from the rights-holder(s). You are free to use this Dissertation in any way that is permitted by the copyright and related rights legislation that applies to your use. For other uses you must obtain permission from the rights-holder(s) directly, unless additional rights are indicated by a Creative Commons license in the record and/ or on the work itself. This Dissertation has been accepted for inclusion in WVU Graduate Theses, Dissertations, and Problem Reports collection by an authorized administrator of The Research Repository @ WVU.

For more information, please contact researchrepository@mail.wvu.edu. 
Narratives of Fracture: Class and Gender in Irish and Indian Postcolonial Domestic Fiction

\author{
Sreya Chatterjee \\ Dissertation submitted \\ to the Eberly College of Arts and Sciences \\ at West Virginia University \\ in partial fulfillment of the requirements for the degree of \\ Doctor of Philosophy in \\ English
}

\author{
Lisa Weihman, Ph.D., Chair \\ Dennis Allen, Ph.D. \\ Gwen Bergner, Ph.D. \\ Marilyn Francus, Ph.D. \\ Keya Ganguly, Ph.D. (External) \\ Department of English
}
Morgantown, West Virginia 2017

Keywords: Ireland, India, Postcolonialism, Gender, Domestic Novel Copyright 2017 Sreya Chatterjee 


\title{
ABSTRACT \\ Narratives of Fracture: Class and Gender in Irish and Indian Postcolonial Domestic Fiction
}

\author{
Sreya Chatterjee
}

The world system, core-periphery, and combined and uneven development - all concepts originating in sociology and economic history have enjoyed a fresh resurgence in literary studies (Moretti 2001, Casanova 2007, Deckard et al 2015). This dissertation studies the novel as a "global form," and explores its conceptual engagement with, as well its inflection by, the changing core-periphery relationship in a globalizing world. I focus on five Irish and Indian women novelists, Elizabeth Bowen, Molly Keane, Jennifer Johnston, Mahasweta Devi and Kiran Desai. Arguably, India and Ireland occupy anomalous and analogous positions in the literary world-system. As a growing cultural-economic power, India is often considered, unfairly according to some critics, to be the representative example of the postcolonial world; such a characterization often obscures the particular and diverse histories of countries in Asia, Africa and Latin America. On the other hand, despite being a part of Great Britain and Europe, Ireland is often situated, controversially, as a postcolony within the "West," on account of its long colonial occupation by the English. By employing a comparative, world-systemic approach between Indian and Irish fiction, I seek to destabilize the West/non-West binary and instead emphasize the shifting relationships between the core and the peripheries shaped by nonmonolithic, distinct kinds of colonialism. Fiction plays a significant part in registering as well as shaping the experience of uneven, postcolonial and peripheral modernity. Specifically, I argue in my dissertation that women's "domestic" fiction, far from being an apolitical, "private" corpus as they are often carelessly labeled, plays a significant role in the literary articulation of postcolonial and peripheral unevenness. The focus on the family in these fictional texts serves to illuminate the interplay between and imbrication of the domestic, the familial and the private with the (gendered) national and the transnational. The authors in this dissertation deserve attention, especially, because through such "domestic" and "private" topics as marriage, comingof-age, sibling relationships and family history, they are able to uniquely elucidate the lived experience of peripheral modernity. Each of the chapters offers a reading of some aspect of the domestic, the familial and the private realms; these women novelists provide a global, and not simply metropolitan, account of domestic fiction, not only in terms of content, but also through formal innovations in their chosen genres of fiction. 


\section{TABLE OF CONTENTS}

CHAPTER ONE: INTRODUCTION

Narratives of Fracture: Class and Gender in Irish

And Indian Postcolonial Domestic Fiction

CHAPTER TWO

25

Thwarted Marriage and the Anglo-Irish Big House:

Elizabeth Bowen's The Last September and

Molly Keane's Good Behavior

CHAPTER THREE

Youth and the Bildungsroman in

Mahasweta Devi's Mother of 1084 and

Jennifer Johnston's Shadows On Our Skin

CHAPTER FOUR

Making It Big: Kiran Desai's

The Inheritance of Loss As A Novel Of Globalization

CHAPTER FIVE

Invoking Troubled Histories: Anne Enright's

The Gathering As A Celtic Tiger Novel

CHAPTER SIX: CONCLUSION 


\section{INTRODUCTION}

\section{NARRATIVES OF FRACTURE: CLASS AND GENDER IN IRISH AND INDIAN POSTCOLONIAL DOMESTIC FICTION}

In a feverish stillness, the intimate recesses of the domestic become sites for history's most intricate invasions. In that displacement, the border between home and world becomes confused; and uncannily, the private and the public become part of each other.

Homi Bhabha, "Narrating the Nation"

In his text, the writer sets up house ... In the end, the writer is not even allowed to live in his writing.

Theodor W. Adorno, Minima Moralia

Domestic space appears as a recurring trope in postcolonial literature, representing a site where the continuous and uneven incursions of history shape everyday lived experience. With its continually shifting relation to the nation and the world, domestic space is fictionalized as alternatively liberatory and repressive: where the fault lines of historical change are most clearly visible. Gendered constructions of domesticity typically emphasize the physical space of the home as feminine, ${ }^{1}$ thereby validating the divide between the private and the public. ${ }^{2}$ These

\footnotetext{
${ }^{1}$ In his seminal study on colonial and postcolonial Indian history Partha Chatterjee speaks of the controversial nationalist resolution of the women's question in India. In the nationalist formulation, Chatterjee argues, the 'home' came to be identified as the "spiritual" sphere based on the relegation of women as bearers of "tradition". The public sphere in which female participation was discouraged became the "material" sphere of masculine social exchange. See "The Nation and its Women" in The Nation and its Fragments. New Jersey: Princeton University Press, 1993.
} 
imbrications embody the internal contradictions of decolonization that expose the interconnected aspects of domesticity and postcolonial nation formation. This dissertation studies women's domestic novel from Ireland and India as a "global" form, exploring its conceptual engagement with politics, gender and the nation in a globalizing world-system. Moreover, by comparing India and Ireland, this dissertation initiates a conversation between earlier, 1980s paradigms of postcolonial studies and later, post-2000s debates around core and periphery in world literature.

Drawing from recent world literature scholars such as Franco Moretti (2001) and others, I deploy the concepts of core and periphery to frame together the ex-colonial, peripheral spaces of India and Ireland. ${ }^{3}$ This is a necessary corrective, I would argue, to the stark neglect of Ireland in a prior moment of the institutionalization of postcolonial studies in the 1980s: a historical moment in which India, on the other hand, is discussed rather prominently. ${ }^{4}$ India and Ireland are both peripheral, in distinct ways, to the capitalist world-system. Not only that, core and periphery offers a useful model of illustrating the analogous relation between the public and the domestic in these contexts. The ideological construction of the public as the site of postcolonial nationalism tends to extract from, and dominate the domestic realm (exactly like the core's appropriation of the colonial peripheries), while simultaneously disavowing and downgrading the centrality of the latter. Reminiscent of the workings of Empire, such a process is deeply gendered and classed, as much as it is based on an engendering of dependency. Women's

${ }^{2}$ Homi K. Bhabha defines the domestic as "unhomely" spaces that narrate the gendered and nonlinear trajectory of the postcolonial nation. See Bhabha's "Introduction: Narrating the Nation" in Nation and Narration. New York: Routledge, 1990.

${ }^{3}$ Moretti's formulation can be usefully summed up as follows: "foreign form, local material and local form ... and it's precisely in the third dimension that these novels seem to be most unstable" (65, emphasis in original).

${ }^{4}$ The rise of postcolonial studies is usually marked from 1978, which saw the publication of Edward Said's Orientalism. Over the next two decades, India plays a particularly outsized role in theorizations of the postcolony, with leading scholars such as Gayatri Spivak, Homi Bhabha, Partha Chatterjee and others. I discuss this history in greater detail below. 
writing, focused on the supposedly dependent and actually disavowed domestic realm is especially committed to rendering such doubly peripheral sites visible, thereby offering a powerful challenge to elite, nationalist maneuvers.

The feminist domestic novel (in contrast to conservative visions of the home) is deeply entrenched in questions of genealogy and family history; it is uniquely situated, for this reason, to illuminate the inflections of history within the intimate alcove of the family and domesticity. In the male nationalist idiom, the family posits "an organic unity of [national] interests," offering "a single genesis narrative for national history" (McClintock 63). The feminist domestic novel problematizes such unity by recuperating the stories of minorities and women as well as underclass and disenfranchised groups such as servants, governesses, and poor relatives who are often marginalized within and dependent upon the family structure. The shifting form of the family at various critical historical moments reflects, in its organic structure, the peculiar social formations of class and gender in postcolonial societies. The concept of domestic space encompasses articulations of the "home," both as physical and ideological space, constituted on the principle of "domesticization, feminization and privatization of society" (Mezei and Briganti 838). As a result it forms an enduring subject of women's writing: complicating, through such "domestic" and "private" topics as marriage, coming-of-age and intra-familial relationships the material ideologies of class privilege and property ownership.

In this dissertation I focus on six exemplary Irish and Indian women novelists - Elizabeth Bowen, Molly Keane, Jennifer Johnston, Mahasweta Devi, Anne Enright and Kiran Desai. These authors deserve attention, especially, because their fiction illuminates the interplay between the domestic, the familial and the private with the (gendered) national and the transnational. Incorporating critical, yet underrepresented moments in Irish and Indian postcolonial history, 
these writers reconfigure the domestic novel as a political form of resistance. In doing so, they re-negotiate the dynamics of the home and the world particularized in certain forms of gendered, Indian and Irish, nationalism.

\section{The Domestic Novel and the Nation}

One of the unvarying aspects of anti-colonial nationalism, globally, has been the gendering of the space of the nation (Meaney 1991; Sarkar 2001; Sinha 2006). Such gendering not only excludes women from active participation in national polity but also reduces their social role to male, nationalist constructs of iconic femininity, in which women are "subsumed symbolically into the national body politic as its boundary and metaphoric limit" (McClintock 62). Women writers working in the field of literature and cultural politics have been, through their articulation of an alternative vocabulary of citizenship, at the forefront of resistance to such processes of appropriation. The domestic novel challenges the hegemonic positioning of the upper class/ upper-caste male as the normative citizen-subject. Instead, it re-orients attention on the fraught aspect of women's identification with the family and the nation-state - represented through the relationship of mothers and daughters, mothers and sons, female friendships, sibling rivalries, and even surrogate friendships forged outside the constraints of patriarchy. Literary representation of such little-acknowledged narratives of belonging unveils a counter-history to the more canonical "imagined communities" and "invented traditions" of the nation (Anderson 1991; Hobsbawm and Ranger 1983). ${ }^{5}$

\footnotetext{
${ }^{5}$ It is important to note that the pioneering early studies of nationalism implicitly prioritize the public/male sphere, both in the case of capitalist print culture of newspapers, books etc. (for Anderson) and the spectacular forms of state power (for Hobsbawm and Ranger). In his wellknown critique of Anderson, similarly, Partha Chatterjee retains the distinction between the public and the private, or what he (rather disingenuously) terms the "material" and "spiritual"
} 
In framing women's fiction as a kind of oppositional history, I draw on materialistfeminist accounts of the use of literary narrative. There has been a notable return to materialist modes of analysis in recent literary scholarship on women's writing. In her important study of African women novelists between 1958 and 1988, Susan Andrade (2011) for example, argues for a dialectical understanding of the figuration of the "family". The family, far from being an apolitical space, Andrade argues, serves as an allegory for the nation and particularizes the myriad ways women (and men) engage with the nation. Similarly, Geetha Ramanathan (2012) in her study of modernity and its resonance across diverse societies in India, Africa, Latin America and the Middle East, questions the validity of "an absolute value" (4, original emphasis). Advocating the conceptual frame of a "global feminist realism," Ramanathan shows how women's fiction draws attention to the class-, caste- and gender-based exclusion of certain sections of society, questioning "whose modernity and what kind" (4). These recent scholarly interventions, among others, posit a productive meeting point between materialist and feminist theories of literature and politics. They provide systematic tools (realism, allegory etc.) for understanding how fiction illustrates crisis-ridden junctures of widely different national histories, including but not limited to neoliberal globalization.

All the novels I discuss represent some typology of domestic fiction that appears during key moments in not only national but also world history. These include the inter-war years, the global sixties as well as the globalization era; they complicate and nuance any monolithic reading of Irish and Indian postcoloniality. Women's writing uncovers, I suggest following

spheres. Women writers, I argue in this project, challenge this rigid separation, as well as the implicit downgrading of the private by highlighting the dialectical interplay between the private and the public. These writers pose literary narratives, or counter-histories as I call them, that constantly foreground the contestations shaping the domestic, deeply political spaces of the home and the family. 
Elleke Boehmer, a specific kind of "discursive materiality": this permits and at times even enables "the forging and testing of particular kinds of affiliation to a national community." (11) The convergence in Irish and Indian women's domestic fiction of the world-historical, the national and the domestic suggest the influence of history as a major determinate category on literary constructions of domesticity and comparative nationalism.

The two case studies I explore in my project, India and Ireland, have distinct but by no means dissimilar literary and historical trajectories. The emergence of the Anglophone novel in India has been the subject of much scholarly debate, focused perhaps unsurprisingly around the novel's contentious figuration of the contemporary nation-state (Gopal 2009). What has gone relatively unnoticed is how postcolonial women's fiction has challenged such imaginaries. Domestic novels by women writers that I discuss here, such as Mahasweta Devi and Kiran Desai, have been instrumental in positing a spatial (allegorical) reading of the postcolonial Indian nation, where the structural changes in the national public sphere are anticipated and criticized, prefigured as it were, through their imaginative re-presentations in the domain of domestic life. The work of writers such as Devi and Desai mark, too, a visible shift in the gender dynamics of the Indian literary scene, linking them with earlier post-Independence Indian women writers such as Anita Desai (Kiran's mother), Nayantara Sahgal, Kamala Markandaya and Shashi Deshpande, who write specifically about experiences related to middle-class domestic life including marriage, motherhood, sexuality and women's oppression under patriarchal family relations. ${ }^{6}$

As Elizabeth Jackson (2010) has correctly pointed out, Markandaya, Sahgal, (Anita)

\footnotetext{
${ }^{6}$ These female writers form a parallel if no-less-important tradition to the domestic fiction written by men. The latter includes such examples as Bankim Chandra Chatterjee's Rajmohan's Wife (1864), which is also the first Anglophone novel in India, as well as $20^{\text {th }}$ century male writers such as Mulk Raj Anand, R.K. Narayan and others.
} 
Desai and Deshpande were members of an "urban intelligentsia" who wrote "fiction rather than feminist analysis" (8). The middle-class domesticity that is often shown to have some subversive and liberatory potential in their work, in fact, struggles to adequately accommodate or engage with grassroots level concerns like child marriage, female feticide, sexual trafficking etc., all of which do not figure prominently in the rhetoric of the domestic novel. Thus in early writing there emerges a fundamental disjuncture in the idea of the so-called "modern" woman, out of the battle to invest domesticity with a transformative potential as well as engage with the systemic sexism that sustains and even, occasionally, supports structural violence towards women. As a result, the narratives that they create often become riddled with the subtext of contradictions and paradoxes that cannot be easily resolved. Later generations of Indian women authors, as we see, tackle this problem in a more direct and engaged way.

Similarly, postcolonial Irish women's fiction, led by writers such as Elizabeth Bowen, Edna O’Brien, Jennifer Johnston and Molly Keane among others, negotiates its own unique space in a literary tradition dominated by the work of Yeats, Synge, Joyce and Beckett. What defines an Irish women's literary tradition, according to Anne Owens Weekes, is the explicit connection of domestic themes with political ones (212). These writers foreground the contestations over personal space, freedom and agency, and resist the gender- and class inequalities that appear at critical points in Irish national history. In particular, in Northern Ireland, the long-drawn challenge of the Troubles since 1968 has meant a symbolic partition in the themes in women's writing from the North and those from the Republic of Ireland. Such a divide has further complicated Northern Irish women writers' self-positioning vis-à-vis the "extravagantly militarized masculine discourses" of national belonging (St. Peter 2).

The women novelists discussed in this project provide a political account of domestic 
fiction, not only in terms of content, but also through formal innovations in their chosen genres. In chapter 2, I discuss how Elizabeth Bowen's The Last September (1928) and Molly Keane's Good Behavior (1981) excavate the Anglo-Irish Big House novel to illustrate the gendered reproduction of the patriarchal family. The Big House novel uses the trope of heterosexual marriage, I argue, to engage with the paradoxes of Irish nation-formation. In Mahasweta Devi's Mother of 1084 (1974) and Jennifer Johnston's Shadows on Our Skin (1977), as I show in chapter 3, these paradoxes are replicated in the genre of the Bildungsroman. Both Devi's and Johnston's novels, with their particular emphasis on female protagonists, complicate the notion of bildung or coming-of-age to highlight the crisis of socialization.

While Chapters 2 and 3 deal with the postcolonial periods, Chapters 4 and 5 offer case studies of globalization-era fiction. ${ }^{7}$ There is a decisive shift from the national to the postnational in these novels, as these fiction texts articulate the changing landscape of nation-states adapting to fundamental shifts in population migration, economic de-regulation, and the rollback of welfare functions. ${ }^{8}$ In countries such as India and Ireland, both former colonies of the British Empire, the impact of these changes is particularly wide-ranging and severe. In The Inheritance of Loss (2006), for example, Kiran Desai explores, with keen insight and political acumen, a familiar theme of the contemporary Anglophone novel: the underdog from the erstwhile colony,

\footnotetext{
${ }^{7}$ For a useful set of discussions around the end of the "postcolonial" and the beginning of the "global", see the essays in Krishnaswamy and Hawley (2007), as well as Loomba et al (2005). The critical scholarship places this transition in the initial years of the $21^{\text {st }}$ century, especially in the aftermath of the US invasion of Iraq in 2003, which marks the sad demise of a post-colonial horizon.

${ }^{8}$ See Pranav Jani's Decentering Rushdie: Cosmopolitanism and the Indian Novel in English. Columbus: Ohio State University Press, 2010. Jani traces the national to post-national shift in the Indian novel written in English. Novels before the 1980s encode what Jani calls "Namak Halal" (true to the salt) cosmopolitanism their thematic use of nation-oriented subjects and motifs. From the 80 s onwards, the Indian novel takes a distinctly "global" or cosmopolitan turn, incorporating issues such as migration, displacement and exile.
} 
and their dream of making it big in in the supposedly multicultural "West". The novel interrogates the conditions under which some ex-colonial, peripheral subjects cross national, territorial as well as familial borders and others do not. These, moreover, parallel the circuits through which literary texts circulate in the Anglophone marketplace. Analogously to Desai, Anne Enright's The Gathering (2007), which is set in the context of the Irish "Celtic Tiger" economic boom of the 1990s, uses the testimonial mode to uncover the history of child sexual abuse. Enright sharply dismantles the story of globalizing Ireland's supposed integration and assimilation into the front ranks of the "West".

An interrogation of the binary of "West/non-West" forms an important part of my reading of these texts, and in the comparisons I draw between India and Ireland. To this end, I use the flexible, relational concepts of core and periphery to set up Indian and Irish responses to postcolonialism and globalism. While these concepts originate in sociology and economic history, they have enjoyed a fresh resurgence in literary studies (Casanova 2007, Deckard et al 2015). These concepts may be particularly useful to the study of domestic fiction since they are not circumscribed by geospatial or cultural assumptions, but engage with literature as part of "a planetary system", to use Franco Moretti's term, in a world that is at once one and deeply unequal (54). They also provide a way of comparison and contrast that I find particularly useful in historicizing diverse, national traditions of fiction writing, moving beyond the critical tendency to categorize Western and non-Western as homogenous, and mutually irreducible entities.

\section{Ireland, India and Core-Periphery}

Ireland and India have a shared history of anti-colonial solidarity, as excellently 
demonstrated in recent work by Michael Silvestri, Gauri Viswanathan, Joseph Lennon and Elleke Boehmer. Such a ready-made analogy is complicated, however, by Irish participation in the British imperial project in India both for Empire and occasionally in opposition to it. The subsequent development of the postcolonial trajectory in Ireland and India has been along very different lines. As a growing cultural-economic power, India is often considered, unfairly according to some critics, to be the representative example of the postcolonial world (Ahmad 1992; Dirlik 1994). On the other hand because of its geographical proximity to Britain and Europe, Ireland has remained underrepresented as a postcolony within the "West", despite having had both an early and late colonial experience.

A small but significant number of Irish postcolonial scholars have worked ceaselessly to resituate Ireland away from British and Europe-centered studies to a more postcolonial-inflected framework. ${ }^{9}$ Ireland provides an example, in the words of David Lloyd, of an "anomalous" instance of colonial underdevelopment outside of the global south, with peculiarities of social formation. Multiple historical factors determined Ireland's controversial status as a postcolony within Western Europe ${ }^{10}$ First, a late colonial struggle for liberation and a post-partition crisis of legitimacy in the North led, according to David Lloyd, to Ireland's fractured itinerary of nation building. This created a deep "recalcitrance" to modernity and modernization in Irish society that was analogous to those of the structurally underdeveloped states in the so-called "Third World" (1999:384). While Ireland's cultural and political structures were shaped by its geo-political

\footnotetext{
${ }^{9}$ I discuss some of the most prominent scholarly examples here. A case in point is the status of canonical Irish writers such as Joyce and Beckett: while they are frequently situated within the fields of British, even trans-Atlantic modernism, it is rarely the case that they are compared with other, more recognizably postcolonial figures, such as say Joyce with the Indian Rabindranath Tagore, or Beckett with the Nigerian Wole Soyinka, and so on.

${ }^{10}$ For a critical discussion of the debates regarding Ireland's status as a postcolonial or colonial space see Stephen Howe's Ireland and Empire: Colonial Legacies in Irish History and Culture. New York: Oxford University Press, 2000.
} 
location, it was at the same time "overdetermined" by its economic backwardness and dependence on the metropole.

Another materialist scholar, Joe Cleary draws attention to Ireland's internal contradictions that exacerbated its seamless merging into the "West". Cleary writes: "the country was perhaps geographically too close to England to be exotic in the manner of India, the Americas or Egypt, and culturally too stubbornly Catholic, too frequently rebellious, too commonly a byword for misery and failed policy to be regarded as a showcase either for the benefits of the Union or for those of imperial progress" (2007:21). As these remarks elucidate, Ireland posits a particularly problematic instance of the integration of peripheral states - marked by modernization, industrial development - into the rubric of an emergent, capitalist worldsystem. A comparative study of Ireland with India thus opens the possibility of testing the ideological weight of binaries such as First/Third World and West/non-West. It uncovers the analogous processes of postcolonial development in the two states, while being attentive to the specificity of Ireland and India as distinct, non-monolithic forms of postcolonialism.

Despite their divergent geo-political locations and the implications thereof, the trajectory of Irish and Indian postcolonial nation-formation overlaps in several critical ways. In the case of India the paradoxes of nation-formation manifested themselves in the postcolonial state's attempts to bring about an accelerated and uneven development through the rapid and erratic transformation of a primarily agrarian, rural economy. The post-Independence reforms in India focused on such transformation following a "Western" (Euro-American), mixed model of accelerated capitalist development combined with the command-economy model of the Soviet Union. This led on one hand to the growing divide between the rich and the poor, the urban based and the rural based populations, and on the other to a pushback against the ideals of social 
welfare and constitutional safeguards advocated during the anti-colonial struggle (Brass 1994, Jani 2010). In more recent years, the rise of the fundamentalist Hindu Right to state power has added a significantly decreased the space for women, minorities, and working-class peoples. ${ }^{11}$

Likewise, a trajectory of uneven and accelerated nation building emerges in case of Ireland. ${ }^{12}$ Like India, Ireland was a primarily rural economy that was subjected, during the postIndependence, Fianna Fail government of De Valera (1932-1948) period to rapid urbanization, industrialization and modernization. Such developments intensified, writes historian Terence Brown, under the aegis of the Lemass government (1959-1966): "a society that had sought its rationale in a separatism justified by national distinctiveness had decided to open itself to the forces of the international marketplace, to seek economic growth as the primary national goal, and to enter fully into the economic and political life of the industrially developed states of Western Europe" (205). This meant however a rejection of the policies of national integration and the weakening of welfare structures leading instead to further economic stagnation and crisis in the 1970s. ${ }^{13}$

${ }^{11}$ The Hindu nationalist BJP (Bharatiya Janata Party) government came to power in 1996, 19982004, and since 2014. An outgrowth of the Rashtriya Swayamsevak Sangh (RSS), which was founded on the model of the Mussolini's fascist Blackshirts in 1925, the BJP-led Hindu Right's "new India" vision is described by multiple observers as combining neoliberal economics with retrograde social conservatism.

${ }^{12}$ Ironically, Ireland remained relatively agrarian and poor for much of the fifty years following the establishment of the Free State in 1922. The increasingly social conservative, Catholic De Valera government initiated multiple policies of industrialization and urbanization, but paradoxically shut out women from government and industry, as well as politics. In both the 1934 and 1937 versions of the so-called "theocratic constitution," the power of the state is invested in the Holy Trinity. Married women were not allowed to keep government jobs, for instance, and multiple references made about the sacred duties of women to the family and to the home.

${ }^{13}$ Brown charts the global oil crisis of 1973 that adversely affected Ireland's fledgling economy. See also Fintan O'Toole's extensive study of Ireland's struggle to integrate into European economy in Enough is Enough: How to Build a New Republic. London: Faber \& Faber, 2010. 
The arrival of academic postcolonial theory in the 1980s during which both Ireland and India re-emerged as subjects of postcolonial inquiry, largely sidestepped their analogous historical patterns of nation building. The rise of institutional postcolonialism meant, at this time, the incorporation of "intellectual concerns and orientations" located generally and attributed specifically to the collective historical and socio-cultural gambit of the "Third World", of which India served as a prime example (Dirlik 503). Irish postcolonial theory, on the other hand, had to grapple with Ireland's paradoxical situation and relation to Western Europe that made it difficult to place it in a comparative frame with postcolonial situations outside of this geo-cultural gambit, such as South Asia or Africa or Latin America (Cleary 2002:104). The 1980s, thus, presented a particularly crucial moment in which the privileging of binary and umbrella terms such as First/Third World, West/non-West, traditional/ modern etc. systematically obfuscated suggestive convergences in the experience of erstwhile colonial spaces, Indian and Irish.

The globalization period marks yet another critical point of convergence for Ireland and India as developing economies in a rapidly changing world-system. In Ireland, which entered the European Union in 1973, the consolidation of transnational capitalist forces heralded the emergence of the celebrated Celtic Tiger period in the early 1990s. This was a moment of major socio-economic change, attempting to fulfill Ireland's historical attempts to integrate economically into the West as a poster-child of neoliberal globalization. In India, a similar rhetoric of economic boom (already in place since the early 1990s) emerged with the popularization of the "India Shining" campaign in 2004. It marked a definite shift from earlier discourses of Third-Worldism, and India's role as a leading light of Non-Alignment in favor of 
greater assimilation into the unipolar, US-led world economy. ${ }^{14}$ Even though the actual social transformation achieved in these "boom" periods were, and still are, widely debated, both Ireland and India witnessed the rise of a globally mobile, beneficiary middle-class with claims to a "normative globality" (Spivak 109).

The uneven development of Irish and Indian society has profound ramifications for their respective literatures, as my discussion of domestic fiction shows. As stated, I think domestic fiction is doubly peripheral, both in relation to the public of elite-led male-dominated nationalism, as well as to the imperialist core of the capitalist world-system. The key paradox it embodies is that colonial-era structural inequalities in Ireland and India are replicated, unsurprisingly, by conservative nationalism as well as the accelerated advent of capitalist globalization. The resulting disjunctures become evident in the breakdown of the fictive "family form" in the domestic novel: due to migrations, forced displacement, the differences in social mobility and access of certain characters over others. Women novelists deploy domestic fiction to challenge, resist, subvert as well as illuminate the myriad contestations, and heightened contradictions, taking place in the marginalized, and disavowed periphery. Because the selected novels correspond to specific historical time periods, they illustrate, sometimes deliberately with political intent and elsewhere unwittingly, the combined and uneven character of their social and political contexts. As such, I want to suggest, these novels reconfigure the genre of domestic fiction as a product of global structural inequalities, as well as the contradictory embodiment of "the grand narrative of the nation" (Gopal 139).

\footnotetext{
14 The Indian state initiated structural adjustment programs in 1991, or liberalization of the economy as these were termed. Beginning with the Bandung Conference of 1954, and the NonAligned Movement in 1961, India had followed a policy of domestic protectionism. This went well with her declared international policy of providing leadership to anti-imperialist, Third World cooperation with other newly decolonized countries in Africa, Asia, and Latin America. Such an international and domestic look changed with the fall of the Soviet Union in 1991.
} 


\section{Domestic Fiction in the Postcolonial Period}

Domestic space uncovers the radical possibility of a spatiality that is not contingent on specific geo-political margins, but rather, exists "in an asymmetrical relationship to the older imperialist centers" both within and beyond the West (Parry 27). Situating Irish and Indian women's domestic fiction under the category of peripheral literature(s) opens up, as I have already argued, the possibility of repudiating binaries such as First/Third World and West/nonWest - or what Neil Lazarus (2002) properly terms "the fetish of the 'West' in postcolonial theory". Instead, it highlights how women writers from such geo-politically diverse spaces as Ireland and India tackle the interrelated issues of gender, nationalism, globalization and capitalism's unequivocal penetration of unevenly developing zones at key moments of worldhistory.

The novels of Elizabeth Bowen, Molly Keane, Jennifer Johnston and Mahasweta Devi may be said to belong to the postcolonial period. The extensive temporal arc of their texts from the 1920 s to the 1970 s covers the inter-war era, the Bandung moment of the mid-1950s and the outbreak of political turmoil in the late sixties. They emphasize, through the mapping of history and its crisis points, a gendered and non-linear trajectory: there is a predominance in their texts of nation-centered themes and motifs that chart the transformation of political power from the colonial to the postcolonial state, the failed promises of male nationalism and repercussions of political reaction in the contexts of Ireland and India. The nation emerges as a powerful trope that reveals, in a dialectical mode, the uneven spatio-temporality of life in the periphery.

Elizabeth Bowen's The Last September (1928) captures the tumultuous moment of the Irish War of Independence. Set in 1919, it depicts the dissolution of the Anglo-Irish, Protestant 
Ascendancy gentry just before the foundation of the Free State in 1922. The Anglo-Irish Big House is a popular trope of Irish postcoloniality, and it is one that Bowen depicts powerfully. In The Last September, this particular edifice is placed at the crossroads of the end of colonialism and the beginning of the postcolonial moment: bringing together complex "extraliterary" texts such as the house itself, family history, political events, and place names, that disrupt the postcolonial juncture of transformation.

Bowen's shaping of a changing Irish society in the inter-war years is paralleled by Molly Keane's Good Behavior (1981), which satirically refashions many of the generic conventions of the Big House novel. ${ }^{15}$ Keane subverts the tension of a transient cultural identity through the invocation of a domestic space - Temple Alice, the Big House described in Good Behavior - in terms of its internal paralysis: the inevitable and slow decay of values associated with Anglo-Irish gentry life. Unlike Bowen's The Last September, where the threat to the Big House is externally constituted in the form of the rural, Catholic Irish nationalists who eventually burn down the Big House, in Keane the threat is internally constituted by the characters themselves whose comic attachment to the traditional grand values of Anglo-Ireland leads to the gradual bleeding away of its resources.

Keane's subversion of the Big House tradition is especially pronounced in terms of gender. While the burning of the Big House in Bowen propels the female protagonist Lois to choose a productive exile in continental Europe rather than remain in Ireland, Keane's retrospective, satirical look at the Big House in Good Behavior demonstrates the impossibility of

\footnotetext{
${ }^{15}$ Another contemporary novel published a decade before Keane's Good Behavior that satirizes the insularity of Anglo-Irish life is J.G. Farrell's novel Troubles (1970). Awarded the "Lost Man Booker Prize" in 2010, Troubles, set in an Irish hotel, provides a funny and deeply critical takedown of the conventions of the Big House genre.
} 
establishing a productive post-independence Anglo-Irish identity: this is achieved through the tragicomic immobility of Aroon St Charles, the protagonist, who is physically trapped by her life in the Big House of Temple Alice. Aroon's entrapment, her obesity, and the general attachment to the grand values of the Ascendancy in Good Behavior provide the novel's dark undertone of satire and wry humor. Published in the 1980s, Keane's re-cycling of the Big House novel paves the way for the "narrower mode of domestic fiction" where the palpable force of nationalism as a transformatory movement is replaced by the everyday, economic challenges of survival in a regressive, backward looking and stagnant social world, and the possibility of anticolonial renewal through progressive citizenship (Krielkamp 1987:456).

Bowen and Keane's novels are important especially because they depict the Anglo-Irish Big House as a key marker of the spatio-temporal unevenness of the Irish polity. The insignificance of the Anglo-Irish in the new Irish Free State, the undesirability of their continuation as a colonial elite, combined with their ironical attachment to antiquated ideals of feudal aristocracy: all signal Ireland's status as the site of a peculiar "spatial collision" between the First and the Third world (Jameson 1990). The paradox of a capitalist modernity for Ireland, David Lloyd argues, lies precisely in the continuity of "damaged remnants of the past" that "find ways to live on in transformation, counterpointing modernity ... by representing ... alternative ways of being (2008:3). Framing Bowen and Keane's novels as distinct reconfigurations of the Big House novel genre, disrupts the inevitable continuity of older, residual, even feudal-colonial social relations into the semantic temporality of "the modern".

If Bowen and Keane capture the socio-political upheavals of anti-colonial nationalism, Jennifer Johnston and Mahasweta Devi invoke the ruptures of postcolonial nation formation through their refashioning of the European Bildungsroman. Specifically, they emphasize the 
constant interplay between the public and the private, in a departure from the exclusively public conventions of the genre. Johnston's Shadows on Our Skin (1977) and Devi's Mother of 1084 (1974) are both novels of the 1970s -- from the 70's. They evoke the political turbulence of the Northern Irish Troubles, and the Indian Naxalite Revolution, respectively. Situating these historical moments of crisis within a global trend of anti-imperialist, anti-capitalist movements, these women writers problematize the very notion of coming-of-age in the unevenly developed periphery. In its journey from the metropole to the periphery, the classical European Bildungsroman transforms from narratives of self-formation in the core capitalist contexts to more contentious modes at the periphery (Esty 2012). Because the individual inhabiting the periphery must navigate an uneven society, their own coming-of-age, marked by selfconsciousness and the transition from childhood to maturity, often remains stalled or incomplete. Devi in particular, reconfigures this (anti)-development in terms of regression rather than progress: she charts an apolitical mother's embracing of the revolutionary Naxalite ideals of her dead teenaged son Brati, in Mother of 1084.

In Johnston's Shadows, another teenager, Joe, is unable to come to terms - both in his love life and his nascent political awareness -- with his country's revolutionary turmoil in which his family is embroiled. The refashioning of the Bildungsroman genre, and their focalization in familial politics, enables these novels to decenter the genre's metropolitan assumptions. As allegories of the nation, the alienation of the protagonists with the passage of time complicates postcolonial notions of progressivism, national belonging and citizenship. Both Johnston and Devi's novels highlight through the distorted Bildungsroman analogous failures of postcolonial nation building in Ireland and India. Setting their stories in moments of political crisis that were 
triggered specifically by the failed promises of decolonization, they emphasize the anachronistic experience of a coeval modernity.

As narratives that are produced before the arrival of academic postcolonial theory, the works of Bowen, Keane, Johnston and Devi complicate a metropolitan, monolithic understanding of the category of "postcolonial" literature. As Neil Lazarus writes, the conceptual rubric of postcolonialism evolved from an essentially temporal (signifying the period following political independence) to an ideological concept in the 80's with the rise of metropolitan postcolonial theory (2011:10). These women writers unveil a radically different mode of identification (or non-identification) with the nation and therefore cannot be uncritically grouped together the paradigm of the "postcolonial". They highlight, rather, the peculiar yet overlapping problems of the periphery.

\section{The Postnational Domestic Novel, or Fictions of Globalization}

Situating the selected novels in a historical frame foregrounds the multimodal implications of the category of the "postcolonial". More importantly it signals a significant departure from the postmodernist, poststructuralist vocabulary of metropolitan postcolonial theory, focusing instead, on the particular materialist ideologies of domesticity as lived experience in specific junctures of history. One must be attentive, as Timothy Brennan and Graham Huggan indicate, of the carefully structured tendency in contemporary theoretical discourse to appropriate postcolonial texts which highlight the "playful" and the "exotic" at the expense of more rigorously combative, contrarian works of literature (Brennan 2006; Huggan 2011). By drawing attention to neglected and disavowed histories such as the Gurkha insurgency and child sexual abuse in the work of Kiran Desai and Anne Enright, respectively, I recover the 
radical possibility of reinscribing alternative histories in mainstream novels of the present moment. More than crafting fictions of globalization therefore, Desai and Enright may be said to be exposing globalization itself as "fiction" - a fabricated narrative of social mobility and quick development that is fractured, uneven and alienating, at its core.

The advent of globalization (in the sense of the global expansion of world-markets) has often been touted as a phenomenon that is effectively predicated on the basis of "a general break with all sorts of pasts" (Appadurai 3). With the incessant movement of labor, information and ideas across national boundaries, the nation is longer a primordial given, but an arbiter, a mediating factor between national subjects and the forces of global capitalism. The idea of a radical break with the past has shaped the contours of postcolonial theory, generating, in the words of Revathi Krishnaswamy, a host of "umbrella" terms such as hybridity, cosmopolitanism, local/global that are frequently invoked without proper context or adequate explanation (3).

The interaction, and in some cases, unwitting collusion of dominant versions of postcolonial theory with neoliberal globalization has been deeply problematic. It is precisely the advocated desire of the former to conceptualize a radical break with the foundational principles of anticolonialism and national liberation that has compromised its conceptual rigor. One of the major pitfalls of metropolitan postcolonial theory, in fact, has been its inability to grasp the profound ramifications of neoliberalism, combined with the core-capitalist pushback against the welfare functions of the state (E. San Juan Jr. 2004; Lazarus 2011). The novels of Kiran Desai and Anne Enright both revolving around the global or post-national themes of corporate capitalism, economic mobility and migration, highlight the impossibility of disengaging with the past. Desai's The Inheritance of Loss (2006) and Enright's The Gathering (2007) as fictions of the globalization era elucidate the alienating effects of an unevenly globalizing world. 
In The Inheritance of Loss (2006), Kiran Desai explores a familiar theme of the contemporary Anglophone novel - the underdog's dream of making it big in the globalizing world. The Inheritance, I posit, offers a self-reflexive account of the global literary marketplace through which novels of globalization are disseminated, enter the canon, and receive recognition (such as the Booker prize). The novel covers a sweeping chronological arc spanning the colonial and post-colonial eras, ending in neoliberal globalization with its promise of "India Shining". ${ }^{16}$ Countering the Indian state's high-minded rhetoric, it offers a devastating critique that illuminates the plight of immigrants, ethnic minorities, as well as women. Biju, one of the central characters, effectively manages to realize the migrant's dream of border crossing, but as a restaurant cook working illegally in New York. He is submerged in the underbelly of the global city, a peripheral figure floating at the margins of the "new" metropole, inside the "West" yet outside it. The other protagonist Sai, a young, globally mobile, privileged Indian woman, gets caught up in her homeland in an indigenous insurgency that is still trying to assert its autonomy from the Indian nation-state.

The dual framing illuminates that a radical break with the past, much celebrated in globalization theory, is never quite achieved in real terms. Through the use of pastiche and flashback storytelling, the novel formally replicates the uneven spatio-temporal process of globalization, which unfolds in an asymmetrical relationship with residual forms of the preglobalization era. Both the underclass worker Biju, as well as the cosmopolitan yet powerless daughter Sai, comes to embody the dialectical interaction between the new local and the global. The novel interrogates the conditions under which some subjects cross borders and others do not,

${ }^{16}$ The Rightist BJP-led government in 2004 initiated the campaign of "India Shining". It sought to paper over the widespread suffering caused by neoliberal restructuring programs, and to realize a majoritarian Hindu cultural ethos - with its downgrading of women and religious minorities - under the rubric of national unity and security. 
critically parallel to the circuits through which literary texts circulate in the Anglophone marketplace.

Analogous to Desai's novel on India Shining, Anne Enright's The Gathering (2007) is set in the context of the Irish "Celtic Tiger" economic boom of the 1990s. Liam and Veronica, the two main characters, are siblings who have drifted apart; at the beginning of the novel, Liam commits suicide from depression in Brighton, England. This news forces Veronica, who leads a comfortable life in Dublin, to return to the place both of them of grew up in, their hometown Broadstone. While The Gathering has been often read as a novel about un-representable trauma, I suggest that its narrative does something more. It offers a testimonial about the relation between memory and history, and the tension created by mobility on siblings and on the family unit. Liam works a lowly hospital job in England, where his duties involve the removal of severed, human body parts and biological waste.

The contrast in their trajectories, between Liam and Veronica, is starkly illuminated by their livelihoods, both involving disembodied human experience, but one categorized as waste and the other as value (lifestyle, money). It is only Liam's death, by suicide, that compels Veronica to engage with the scandals of the past, Liam's childhood sexual abuse that his family had ignored, as well as his invisibility in her present, blissful life. The forced incursion of a devastating family history into Veronica's perfectly ordered family life reminds one of the uneven space-time of contemporary Ireland. Even as the Celtic Tiger boom uplifts Veronica, the destroyed life of Liam upsets the story of globalizing Ireland's integration and assimilation into the front ranks of the "West".

The substantive corpus of women's writing from Ireland and India, both in the 
postcolonial periods as well as in the globalization era, foregrounds the ideological contestation between feminism and nationalism: indeed, the historical frame of the project show cases the myriad inflections in this contestation and its articulations in literature. Like anti-colonial nationalisms elsewhere in the developing world, Irish and Indian nationalisms converged in their constructions of iconic femininity, in the perpetuation and active promotion of the idea of the nation as "en-gendered", feminine space (Boehmer 2005). Such discourses fixated on the concept of a Mother India, and its Irish counterparts such as Cathleen ni Houlihan and Cailleach Beara. ${ }^{17}$ These constructions, entrenched as they were in cultural discourse, had a deep structuring influence both on representations of women in literature as well as on literature by women.

My use of materialist theories of combined and uneven development thus seeks to engage critically with the notion of the "domestic" that is contingent on ideas of the nation in an uneven and unequal world-system. The category of a peripheral or coeval modernity as it manifests itself within the realm of the domestic may be best understood, I maintain, through everyday lived experience. Domestic fiction by women recuperates and reorients such experiences by focusing on the most quotidian battles of family life, the most intricate tensions, romantic intrigues, alienation and physical displacement. Such experiences are far from "apolitical", "private" and "self-contained". Rather they highlight the unique social relations that emerge from the coexistence of the modern with the antiquated, the globalized and the parochial, the residual and

${ }^{17}$ Mother India was the name of a 1957 Indian nationalist film directed by Mehboob Khan. Conceived in the late $19^{\text {th }}$ century, the idea connects the nation to a (Hindu) mother-goddess as its presiding deity, Bharat Mata. Cathleen (alternately spelt as "Kathleen") ni Houlihan was the name of the 1902 play put up by William Butler Yeats and Lady Gregory, and refers to the mythic symbol of Irish nationalism, an old woman without a home. Cailleach Beara refers to a Gaelic myth, of an ancestral deity often associated with the weather goddess. 
the emergent (Williams 1977) - to reveal the profoundly incongruous effects of capitalist modernity. 


\section{CHAPTER TWO}

\section{THWARTED MARRIAGE AND THE ANGLO-IRISH BIG HOUSE: ELIZABETH BOWEN'S THE LAST SEPTEMBER AND MOLLY KEANE'S GOOD BEHAVIOR}

This chapter explores the work of two Irish women novelists, Elizabeth Bowen and Molly Keane, and discusses how these writers refashion the conventions of the domestic novel to launch a critique of gender and class ideologies in twentieth century Ireland. Both Bowen and Keane focus their attention on the Big House, depicting the dissolution of the Anglo-Irish, Protestant Ascendancy gentry during the epoch of the Irish Revolution and the foundation of the Irish Free State in 1922. In doing so, their novels, Bowen's The Last September (1929) and Keane's Good Behavior (1981), undertake the important political work of resisting dominant nationalist myth-making as well as articulating alternative progressive visions.

The Anglo-Irish gentry present a peculiar social phenomenon. On one hand, this group claims a somewhat exceptional status as representatives of an "aristocratic ur-Celtism" (Kreilkamp 11). This figuration, and the Anglo-Irish association with a unique, authentic "Irishness" have gained significant traction, re-emerging particularly since the decade of the 1980 s through heritage tourism. On the other hand, the Anglo-Irish gentry are the object of nationalist suspicion both in terms of their elite economic position and Protestant religious affiliation. During the Irish nationalist movement (1919-1922), the Anglo-Irish were the target of widespread popular violence and resentment that were focalized in the destruction of estates or "Big Houses" as these were termed. The situation is complicated even further by the fact that 
despite their indifferent "caste-snobbery" to Irish nationalist aspirations, the Anglo-Irish continued to consider themselves as "unambiguously Irish, indeed Irish in one of the best possible ways", as Terence Brown contends (83).

The term "Anglo-Irish" is itself of recent origin. Emerging only as of the late $19^{\text {th }}$ century, the term Anglo-Irish and the gentry class associated with it became the focal point of resistance for what W.J. McCormack has termed the "ever more confident alliance of nationalism and ultramontane Catholicism" (1993:181). The Anglo-Irish Ascendancy established a veritable "social apartheid" against the predominantly Catholic population of peasants and middle-class proprietors, the major constituents of early $20^{\text {th }}$ century Irish nationalism (Genet). ${ }^{1}$ Nationalist resistance to the Anglo-Irish manifested in the destruction of the latter's Big House estates: during the revolutionary period, some scholars suggest that more than seventy such estates were pillaged and destroyed (Dooley 2001), while others argue that the destruction was even greater, nearing the figure of two hundred (Donnelly 2012).

The figurative space of the Anglo-Irish Ascendancy in Ireland is inflected by the latter's peculiar postcolonial history. Fredric Jameson (1990) describes Ireland as the product of a unique "spatial collision" between the first- and the third-world. By the early twentieth century, Ireland becomes what Jameson calls, "a radically different kind of space, a space no longer central, as in English life, but marked as marginal and ex-centric after the fashion of the colonized areas of the imperial system" (60-61). Jameson reads James Joyce's Ulysses (1920) as a text made possibly only by a "misplaced" and fractured modernism that combines the

${ }^{1}$ The Ascendancy refers to the group of landholding Protestants who controlled much of the church and state till the early $20^{\text {th }}$ century, only to be displaced by the rise of Irish nationalism. Although a tiny minority, the Protestant Ascendancy class exercised enormous influence over Irish life for much of the $18^{\text {th }}$ and $19^{\text {th }}$ centuries. 
representational and aesthetic strategies of the metropolitan "West" with the "radical otherness of colonial life" (51). ${ }^{2}$ Echoing this observation, Luke Gibbon notes, "Ireland is a first-world country, but with a third-world memory" (3). While Ireland can be very usefully studied from the standpoint of postcolonial theory (Deane 1996; Kiberd 1996), the specificity and particularity of the modern Irish experience lies (unlike ex-colonies in the Global South) in its spatial proximity to its colonizing country, England, as well as its geographical location -- and increasingly since the 1980s, economic integration -- within the European Union.

In $20^{\text {th }}$ century Irish fiction, the Anglo-Irish Big House emerges as a key marker of the spatio-temporal unevenness of the Irish polity. The decaying, crumbling Big House serves a dual role. On one hand, it underscores the fragility and helplessness of a colonial elite that is dependent on continued English patronage for its survival. This is evidenced both by the relatively insignificant role of the Ascendancy in Irish national life after the establishment of the Free State, but even more keenly in the diminished and often modest structures that the term Big House actually referenced. ${ }^{3}$ On the other hand, the Big House represented what Jacqueline Genet describes as an architectural emblem of imperial power separated from its surrounding landscape: fundamentally foreign, elite and oppressive. It is only at the point of its dissolution that the Big House becomes a major trope in Irish literature; until then, "its economic, social, political or legal implications had been too overwhelming to be transferred to fiction" (Genet

${ }^{2}$ Jameson is by no means alone in positing a theory of peripheral modernism as misplaced or dislocated, which combines elements of metropolitan aesthetic form with aspects of local, colonial patterns. For an influential study of peripheral modernism in the Latin American context, focusing on $19^{\text {th }}$ century Brazil see Schwarz 1992.

${ }^{3}$ Many significant figures of early revolutionary nationalism paradoxically came out of the Ascendancy, such as Yeats and Constance Markievicz. This shifted to a Catholic, largely republican base of power in the 1930s with the rise of de Valera's Fianna Fail government in 1932. 
16). The Big House and its negative associations contend with a seemingly antithetical notion: Anglo-Irish revivalist nostalgia.

Noted postcolonialist scholars such as Declan Kiberd and Seamus Deane have been, somewhat justifiably, critical of the revivalist trend that picks up in the second half of the $20^{\text {th }}$ century. Deane, for example, harshly criticizes the cultural nostalgia for the Big House as illustrating the "poverty" of postwar Irish literature, part of a larger failure of the decolonization process. He sees the nostalgia for the Anglo-Irish as symptomatic of "the half-made, half-baked, ... the hyphenated status of a colony that cannot, precisely because of its hyphen, ever achieve fullness of being" (21). More to the point, Kiberd notes that the figure of the "ruined landlord" in Big House revivalism is a sentimental projection of a city-based postcolonial elite, which ideologically conflates the landless agricultural laborer and the penurious Anglo-Irish gentry class as both equally representative of a mythical Irish rural (483).

The revival of the Big House illuminates a process of cultural and national mythmaking, albeit one that has been challenged in several ways. ${ }^{4}$ In the immediate aftermath of Irish Independence, the Big House is presented as out-of-sync with the time and place of the postcolonial nation, an obstacle to historical progress that needs to be overcome. This is a widespread sentiment echoed by secular nationalist, Catholic as well as progressive sections of the Anglo-Irish Ascendancy. Since the postwar era, however, such non-synchronicity is elevated to the level of the trans-historical. Belonging to a mythologized Irish past, the disappeared Big

\footnotetext{
${ }^{4}$ Not all of the interest in the Big House is adulatory: indeed, as Vera Kreilkamp's monograph argues, a significant intervention in this regard has been by women writers, such as Molly Keane, Jennifer Johnston and others, who critique and in many ways subversively rewrite the class and gender expectations of the genre. The conceptual tools of postcolonialist, feminist and Marxist theory guide much of the critical interest in the Big House, coupled with a renewed interest in Gothic fiction.
} 
House - a lost marker of authenticity - remains outside of time and space, and is thereby reinscribed within the postcolonial present. Needless to say, such trans-historical reconfiguration and reinscribing serves to mystify the failures, what Deane calls the "incomplete"-ness, of decolonization - instead, it serves to create "imagined communities" and "invented traditions" of the nation (Anderson 1991; Hobsbawm and Ranger 1983).

The attempt at constructing cultural nostalgia has met with multiple challenges, not least of which is the contrarian tradition of Anglo-Irish Big House fiction. What has gone relatively unnoticed is the role of women novelists in this tradition. As Vera Kreilkamp suggests in her important monograph, Anglo-Irish women writers, starting from Maria Edgeworth (Castle Rackrent, 1800), Edith Somerville (The Real Charlotte, 1894), Somerville and Violet "Martin Ross" (The Big House of Inver, 1925) have exposed the inequities of the Big House with "relentless irony". "Central to the Big House [fiction] tradition", Kreilkamp argues, "is a deeply ironic and, for the most part, unsentimental vision of gentry life as the ascendancy world moves towards collapse." (21) This is particularly true for the $20^{\text {th }}$ century women novelists who persistently demystify the social life of the Anglo-Irish Ascendancy.

The work of Elizabeth Bowen and Molly Keane, I will argue in this chapter, intervene in the process of ideological mythmaking by inserting the Big House back into history. They do this by foregrounding the role of young female protagonists, and the theme of "thwarted marriage" that illustrate the impossibility, and undesirability, of the continuation of the Big House. In Bowen's The Last September, the heroine Lois, Ascendancy daughter of the Big House of Danielstown, chooses a life of independence after her aunt and guardian, Lady Naylor, blocks her potential marriage to the English soldier, Gerald. The novel offers an obvious parallel between Lois and the newly independent Irish nation of the 1920s, both affirming a vision of life 
beyond the British Empire (Gerald, in fact, is killed by nationalist guerrillas). Bowen is "strikingly disloyal", to use Kreilkamp's evocative phrase (157), to the Ascendancy class whose destruction is signified at the end of the novel by the burning down of Danielstown. An even more disloyal, and strikingly ironic account of the Ascendancy is presented in Keane's Good Behavior. The novel's heroine, the Ascendancy heiress of the Big House of Temple Alice, Aroon, kills her own mother at the beginning of the novel, and is repeatedly frustrated in her attempts to marry into the English aristocracy. The novel's parody of the codes of "good behavior", as I show below, challenges the renewed Ascendancy myth in 1980s Ireland spurred by the state's promotion of heritage tourism. Indirectly, Keane satirizes the self-defeating Irish efforts to use heritage and pleasure tourism to join the front ranks of the "West."

Significantly, both Bowen and Keane bring attention to the often-ignored realms of the "domestic" and the "home", interrogating the processes by which such sites perform the ideological work of reproducing dominant structures of exploitation and oppression - in terms of gender and class. Feminist fiction, as Sara Upstone notes, frequently re-politicizes seemingly apolitical spaces such as the home: achieving a "reversal of representation, in which home is no longer presented in denial of its political status to construct a colonial ideal, but explicitly [foregrounds] the political" (115). Antoinette Burton, similarly, describes women's engagement with home "as a material archive for history and a very real political figure in an extended moment of historical crisis (5, original emphasis). Thus, Anglo-Irish women writers' preoccupation with what Genet calls the "mysterious intricacies of illegitimacy, land-hunger, inbreeding and insanity" (17), needs to be read in light of their politicization of these issues previously ignored by a predominantly male canon. 
In Big House fiction, the theme of stalled or thwarted marriage serves to illuminate the colonial (England-dependent) character of the Anglo-Irish gentry. The unstable, and steadily declining dominance of the gentry class over the rest of the country is refracted in the domestic sphere of the Big House. This is manifested by the destabilization of "traditional" gender roles and the dissolution of unity and harmony characteristic of the feudal-colonial order. The thwarting of marriage calls into question the inheritance and reproduction of patriarchal norms of property, as well as gender relations. As Kreilkamp writes:

In many of the novels, beginning with Castle Rackrent (1800), ascendancy families fail to produce heirs, and legitimate lines of succession are threatened. When children do appear, they usually remain trapped, festering within the walls of the Big House; they are often sexually dysfunctional, often victimized by their powerful mothers. In late nineteenth- and early twentieth-century fiction, the role of women in the Big House becomes increasingly dominant. As patriarchal colonial landlords become marginalized by the decline of their social, economic, and political power, Big House wives begin to dominate the novels. Particularly in fiction by women ... ruthless gentry chatelaines mimic the roles abdicated by defeated and increasingly impotent landlords. Without an adequate social and political arena for their ambitions, however, these women prey not on a dwindling tenant or servant class, but on their own children. Thus with the decline of imperialism, the colonizers turn the habits of a moribund political system inward and savagely attack their young. (23)

Inter-generational conflicts between parents, especially "powerful", "ruthless" mothers, and children, especially "sexually dysfunctional", "victimized" daughters, serve to vividly illustrate the tensions within the Big House. They represent the inward turning of a social conflict that is external to the Big House, threatening its continued existence. The young women in these novels underscore the dramatic rupture in Anglo-Irish social reproduction and genealogical continuity -- 
by remaining confined within the natal Big House, failing to produce their own children through marriage, or breaking away and disavowing the Big House altogether. In this way, Big House fiction manifests the dialectical interplay between the internal and the external, the home and the world.

This is most clearly illustrated in the representation of the Big House itself, whose "architecture takes the place of [inner] psychology", and within which "character is shaped by rooms and corridors, doors and windows, arches and columns, rather than by individual experience" (Ellman 43). In both determining, and reflecting the individual character of its inhabitants, the architecture of the Big House illuminates what Marx (1967) terms the "fetish character of the commodity-object", that is a dialectical interplay between the human and the social, and the historical and the natural. Employing a Derridean register, Bowen scholars have described the figuration of the Big House as "palimpsested by the 'prints' of the dead generations" (Ellman 42) as well a "ghostly colonial world that represents the Gothic" (Lassner and Dergider 196). Both Elizabeth Bowen and Molly Keane successfully adapt elements of the Gothic in their novels. This allows their novels to engage with earlier, nineteenth century Big House fiction, and also bring renewed attention to the colonial and patriarchal nature of the Anglo-Irish Big House.

There is more than a hint of autobiography in Elizabeth Bowen's writings on the Big House. Both The Last September (1929) and the non-fictional Bowen's Court (1942) draw directly from her personal history as the female heir to the country manor in Kildorrery, County 
Cork. ${ }^{5}$ While it is not my intention to reduce Bowen's writing to biographical details, it is nevertheless possible to note the influence of her personal circumstances, the only child of parents and a childless heir to the family estate, to the themes that animate the fictional world of The Last September. These include marriage, the paradoxes of female friendship and guardianship, and the relevance of the Big House gentry in a changed post-Independence Ireland. The focus on the fractured family, in particular, is not limited to The Last September. As Heather Bryant Jordan writes, "no Bowen tale represents a traditional complete family; her stories abound with out-of-wedlock pregnancies, hushed miscarriages, and children left to be raised by distant aunts and uncles" (48). The intimately personal yet Gothic tone of The Last September, characteristic of Bowen's style, makes the text a distinctive example of the $20^{\text {th }}$ century Big House novel.

"Danielstown", the big house of the novel, belongs to Lord and Lady Naylor who live there with their nephew and niece, Laurence and Lois. Lois, the novel's heroine is related to the Naylors through her mother, Laura. Orphaned at an early age, Lois is brought up by her uncle and aunt who have no children of their own. The story begins with the arrival of two longexpected guests at Danielstown, Hugo and Francie Montmorency. Hugo is a typical example of the directionless, impractical Ascendancy gentleman. He squandered his family fortune in a series of bad investments, and still hopes and plans for another utopian undertaking in distant Canada. Francie, his wife is several years older to him, and of a sickly disposition. The

${ }^{5}$ Cork was arguably the most affected region in the political turmoil of the Irish Revolution. In the preface to the American edition of the novel, Elizabeth Bowen notes that although her own family estate remained untouched by political events, unlike the fiction Danielstown manor that burns down in The Last September, this "terrible" fictional event is derived from her anxieties about the estate. Testifying to the personal nature of the novel, Bowen sees The Last September as "nearest to my heart", "a work of instinct rather than knowledge". See Ellmann's (2003) intellectual biography for the impact of Bowen's life on her fiction; for the history of Big House and estate destructions of the 1919-1921 period, see Dooley 2001 and Donnelly 2012. 
Montmorency's arrival to Danielstown excites the youthful Lois, and provides a respite to her monotonous social existence. At the same time, the depiction of the assembled group enables the novel to launch a social critique of the Anglo-Irish Ascendancy.

At the beginning of the novel, Danielstown is presented as already at the brink of disintegration. The opening section pointedly draws attention to the physical condition of the house. The sunlight coming through the "high windows" is "frayed", but even this frayed sunlight had "blistered" the windowsills and faded the color of the high-backed chairs. Photographs, displaying people and events from the past, "gave out from the walls a vague depression". The denial of the regenerative power of sunlight, and the images of dead forefathers on the walls, suggests the similarity of the house to a tomb. This symbolism is further intensified by references to stuffed, dead animals, which emit a morbid odor of camphor and animal skins. The odor fills the rooms, even as "the glare of morning still hung like dust on the evening chill", suggesting the lack of air circulation. The items inside the house even hinder movement; "Lois often tripped with her toe in the jaws of a tiger; a false step at any time sent some great claw skidding over the polish" (7). Two mammoth bookcases, whose keys had been lost, display a range of relics invoking a lost, more glorious past. As the reference to the "jaws of a tiger" suggest, the house is marked by the legacy of colonialism everywhere.

If the Big House represents a slow and painful decay, it provides a stark contrast to the surrounding of the house that is simmering with vitality. There is a peculiar interaction between the house and the surrounding landscape; the latter seems to shield the house and threaten it at the same time. The house is cocooned by a screen of trees that "reached like an arm from behind the house", embracing and simultaneously engulfing it. The trees that ensconce the house assume, a little further in the distance, the menacing character of a dark "deepening forest". The 
"orange" sky, visible from behind the trees not only "press[es] in from the open and empty country like an invasion", but also "smoulder[s]" it with an ominous brightness that is reflected in the mirrors and wallpapers of the house (25). The image of the brightly lit orange sky illuminating the rooms invokes the idea of a great fire engulfing the most private spaces of Danielstown. This is a proleptic image, indicating the fate that awaits the house. The idea of a Big House out of sync with the surrounding is repeated later in the novel, when we see once again, "the house seemed to be pressing down low in apprehension, hiding its face ... huddl[ing] its trees close in fright and amazement at the ... unloving country, the unwilling bosom whereon it was set." (92, emphases added).

With its furniture in various degrees of disintegration, Danielstown is emblematic of the decline of the Naylor family; this is a running trope of the Big House found in the $19^{\text {th }}$ century novels of Maria Edgeworth, and Somerville and Ross. Such a representation is usually meant to evoke the reader's sympathy. In The Last September, however, decay functions as a powerful allegory of social transformation: a nostalgic reaction to the lost family home merges with an anticipation of the postcolonial future. Marking the co-existence of past grandeur and present decay, the Big House foregrounds a contradiction in the social order that makes a transformation inevitable, and in fact desirable. For Bowen, the decaying Big House supplies what Seamus Deane calls a necessary "spectacle of ruin" (Deane 1996), on the back of which the postcolonial future can be particularized. ${ }^{6}$

\footnotetext{
${ }^{6}$ Seamus Deane's remark recall Walter Benjamin's The Origin of German Tragic Drama, where the latter comments that, "allegories are, in the realm of thoughts, what ruins are in the realm of things" (177-78). For Benjamin, ruins allow us to see through the illusory claim of historical progress in the same way that allegory serves to concretely embody the juxtaposition of incommensurable entities. At the cusp of Irish Independence, the Big House stands in for material ruin and representative allegory, a double marker of a vanquished Ascendancy past.
} 
From the very beginning, Bowen builds up a tension between the inhabitants of the Big House and the Irish nationalist guerillas who operate surreptitiously in the fringes of the demesne. As soon as the Montmorencys arrive, Lady Naylor queries if they had to face any "trouble": "You came quite safe? No trouble? ... Nobody stopped you?" (4). The repetitive questions reinforce the urgency of the situation, and hint at the frequency and regularity of army interceptions, ambushes and IRA attacks. As the family settles down to dinner, the conversation inevitably turns to the political situation. It comes to light that the revolutionaries as well as the army have been digging in various Ascendancy estates for guns, albeit for antithetical reasons.

The anxiety about the political situation serves as an ironic backdrop to the false sense of fulfillment and harmony symbolized by the family dinner. The episode strongly reinforces the idea that even seemingly mundane activities within the Big House, such as a dinner, must be tinged with apprehension and overwhelming tension. Every conversation and action becomes a mere performance, sustaining a façade of normality. In the mystical play of light and dark in the dining room, the gathered group seems "unconvincingly painted, startled, transitory.” Sitting around the dinner table, the family appeared to have "dwindled personally," resembling the shrunken portraits hanging high on the walls. They are "frozen" in time like the "damask birds and roses" engraved into the huge dinner table (28). The portraits "cancelled time, negative personality and made of the lower cheerfulness, dining and talking, the faintest exterior friction". The unmistakably Gothic tone of Bowen's language, invoking a past now frozen into memorabilia emphasizes the ephemerality of the characters and of the scene itself. The critic Anna Teekell has observed the tendency of Bowen's prose to be "riddled with inversions, ellipses, subjunctives" (61). Sentences often remain unfinished, references obscure and 
incomplete. The impotency of words that can never translate into concrete action captures the contradiction of a world suspended in time.

The behavior of the different characters also betrays clues about the generational divide that separate them. Soon after dinner the characters sit out on the steps for a casual chitchat, after much deliberation as to whether or not it is safe to do so. Their peace is rudely broken by the sound of an army truck gyrating along the uneven road around their demesne. The sound has a psychological and pathological effect; it "echoed down the spines of the listeners. They heard [it] with a sense of complexity". While the others are on tenterhooks, Lady Naylor intervenes to dissipate the tension. She casually remarks that she would have invited "the poor fellows in to have coffee" (38). Lady Naylor's self-assured tone is based on her ability to maintain an air of seeming normalcy in the face of impending doom. But it also illustrates the vulnerability and helplessness of someone in her class. Her situation is tragic and ironic: it is only through elite condescension and the denial of any sense of crisis that she can validate their superiority in a context where they are no longer relevant.

If Lady Naylor's attitude is one of denial, her husband Sir Richard's is one of perplexity, not knowing "what the country was coming to". In a rather comical tirade, Richard reports that he had been held up sometime back, "by a thing like a coffee-pot ... with a little brute of a fellow bobbing in and out ... from under the lid at the top". What Sir Richard describes is in fact an armored military car. To his mind however, it resembles an ordinary domestic coffee pot. Echoing his wife's comment about inviting the soldiers in for coffee, this comment provides yet another example of the older generation trivializing what is a very serious war-like situation. At the same time, it is a poignant reminder of the advent of a modernity that is at odds with the 
Naylors' way of life. The armored military vehicle appears in their lives just as, as Richard quaintly puts it, "when we'd get the horses accustomed to motors" (30).

In contrast to Sir Richard and Lady Naylor's perplexity and denial, the younger generation represented by Lois and Laurence offers another perspective. They demonstrate their awareness of the political situation, even though they do not know how to engage with it at a conceptual level. This is evident in Laurence's declaration that the revolution is "closing in" on them, and in Lois's plea that they "ought to know" (29) more about the political situation. Laurence and Lois posit an interesting subversion of the social roles of the two generations. By professing her desire "to know," Lois acknowledges the cycle of history as it unfolds before their very eyes. In accepting, and even desiring historical change, Lois demonstrates an intellectual and emotional maturity that arguably differentiates her perspective from that of the older characters.

Like Lois, Laurence too represents the ideological conundrum of youth caught at the crossroads of a decadent past and an uncertain future. Like the Shakespearean "Fool," Laurence articulates what the others hold back, displaying a sharp wit and studied detachment. An Oxfordreturned intellectual, Laurence dramatizes the monotony and indulgence of his life within the Big House. Not only does he deny having any emotional life, but like the Fool he also lives "from meal to meal" (6). During the dinner, Laurence spells out what his aunt and uncle wish to deny the rising agitation in the surrounding areas. Promptly dismissing Hugo Montmorency's attempts at polite dinner-table conversation, Laurence proclaims that the revolution "seem to be closing in ... rolling up rather" (28). His grim forecast is validated when it is revealed during the course of the evening that the revolutionaries were planting firearms in the gardens surrounding the Big House, in order to evade the army. 
That night, it is Lois who becomes a chance witness to the revolutionaries. Lois encounters a "stranger" walking across their demesne. In contrast to the man's "resolute profile," she finds herself "immovable, blotted out in the black": invisible to the "stranger", she watches him walk down their garden path. It is a symbolically charged intersection, of paths of life from inside the big house and those from beyond it. The contrast between the inside and the outside provides a prolepsis for later events in the novel. What is interesting, however, is that Lois even without recognizing this person associates him with the nationalist struggle: "it must be because of Ireland that he was in such a hurry." She on the other hand, "could not conceive of her country emotionally". For Lois, recognition of this unfathomable chasm creates a sense of foreboding, "a doom of extinction" (42). She conceives of herself vanishing in the dark in her black dress, a "country-less" being.

The contradictory nature of Lois's relationship with the nation illuminates her status as a young woman caught at a particularly unstable juncture of Irish society. As a daughter of the Big House, perceived as a symbol of feudal-colonial oppression, Lois cannot be ideologically linked to the Caitlin Ní Uallacháin figure. ${ }^{7}$ Yet the uncertainty of her future growth corresponds thematically with that of the nation, both coming-of-age in a period of drastic social and political transformations. For the critic Jed Esty, who reads The Last September as a case of a failed Bildungsroman, Lois" stalled development symbolizes "the historically fixed, politically vexed, permanently adolescent status of the Ascendancy itself" (181). When conceived in relation to the Ascendancy class, Lois's youth becomes an overdetermined trope for the permanently frozen

${ }^{7}$ Caitlin Ni Uallacháin or Cathleen ni Houlihan is a mythical symbol or emblem associated with Ireland's nationalist struggle. It is often represented as a feminine figure also idolized as Mother Ireland. A one-act play co-authored by Lady Gregory and William Butler Yeats in 1902, titled "Cathleen ni Houlihan" is considered one of the most iconic representations of the figure in theater. 
adolescence of the ancien régime. In relation to the larger context of nationalist war, however, her youth becomes a symbol of indeterminacy and chaos. She must eventually dissociate from her class background and link to the emerging nation.

This contradiction finds its most keen expression through the thwarted marriage plot of The Last September. As a child of the Ascendancy, standing at the threshold of womanhood as well as maturity, Lois's future is ostensibly tied to her ability to marry and marry well. Throughout the novel, family members voice their concerns and speculations on the subject: particularly since, as Hugo puts it, there seems to be "a great many unmarried women" in their social circle (56). These unnamed spinsters serve as a warning, for the fate that awaits both the unmarried Lois as well as the perpetuation of the Ascendancy as a class. Her relatives want Lois to find a groom among the English soldiers stationed close to the manor at Clonmore. Clonmore provides plenty of opportunity for social mingling, but for Lois the soldiers seem to be "blocking her mental view by their extreme closeness," as they "moved shadowless in a kind of social glare numbing to the imagination" (12). Lois' ideas of love and marriage are based on intellectual companionship and compatibility, not to mention a spirit of exploration, adventure and discovery. As well, she betrays an elite sophistication of taste and manners not easily found in the English soldiers. Unwilling to enter into a compromise marriage, Lois visualizes herself fifty years ahead, still living in the house of her uncle and aunt (36).

Lois's romantic notions condition her response to the two male characters she comes in close contact with, her gay cousin Laurence and her ardent if slightly inert lover, Gerald Lesworth. Laurence takes a mischievous, almost chauvinistic pleasure in denying Lois her due respect and acknowledgement as an individual. Yet paradoxically she feels comfortable speaking to him, "because of his indifference to every shade of her personality" (9). Laurence's lack of 
interest encourages her to "come out ... with assertions surprising at times to herself": it is a crucial catalyst for her growing awareness of female individuality and personhood. She humors him with a deliberate display of "unfathomable silliness", thereby confirming his patronizing impression of her.

On the other hand, Gerald Lesworth, the English young subaltern in 'The First Rutlands', a regiment stationed at Clonmore provides a stark contrast to Laurence. He is in love with Lois. However, Gerald is perpetually caught between his emotions for Lois and a staunch sense of duty for his nation. The paradox of his status as a prospective romantic "hero" is that no one in the Big House of Danielstown is ready to take him seriously in that role. The only identity ascribed to him is that of the colonizer and outsider. Laurence in particular teases out this contradiction by asking for Gerald's "point of view" on the Irish question. The episode, and Gerald's leaden-footed response, heightens the irony of his position:

"Well the situation's rotten. But it is right"

"Why?"

"Well ... from the point of view of civilization. Also you see they don't fight clean" "Oh, there's no public school spirit in Ireland. But do tell me - what do you mean by civilization?"

$$
\text { “Oh - ours" (132). }
$$

The dialogue achieves an almost dramatic effect - bringing out the unbridgeable gap between their positions - Laurence as the modern native intellectual, and Gerald as the comically ardent upholder of "the white man's burden". Gerard is only a pretender to the "public school spirit", something Laurence recognizes. The irony is compounded by the fact that they, Laurence and Gerald, represent a political alliance, a united opposition to the nationalist guerrillas. Gerald is sincere but also stupid, and he is no match for the keen, ironic intellect of Laurence (and Lois). 
And even though he is not very refined himself, he is deeply complicit in the persistent colonial onslaught on Ireland, doggedly mouthing the excuse of "civilization".

The novel repeatedly underscores how unsuitable Gerald is as a future partner to Lois, in social standing, intellect, and as a model of masculinity, even as this alliance is precisely what is needed, politically, for the survival of the Ascendancy in general and Danielstown in particular. Bowen's depiction of Gerald is carefully poised between a critique of English imperialism and the masculinist ethos of the military. These complementary strains appear throughout the narrative, marking Gerald as somewhat inert, uninspiring and very predictable. Gerald wishes to, but is unable to explain to Laurence that, "it was with some awareness of misdirection, even of paradox that he was out here to hunt and shoot the Irish" (133). He has to look for his "pocketbook" on another military commander, Napoleon Bonaparte, to conjure up a suitable historical example. Gerald's reliance on his pocket book for Napoleon's political views speaks to his ideological training in the art of colonial conquest. At the same time, it reveals with comic irony (to Lois and Laurence) his crudely plebeian and "textbook" induced view of the world, unable to find any other way of justifying himself. Gerald wishes to derive validation from history for his civilizing mission to Ireland. His manner of doing so, however, appears deeply unconvincing if not ridiculous to his prospective "wife".

A predictable form of soldierly machismo colors Gerald's view of Lois as well. Gerald mistakes Lois' ambivalence towards him as a sign of her girlish frivolousness. He feels that she, being a woman, would never understand his feelings: "she wasn't made to know, she was not fit for it" (67). The novel ruthlessly lampoons Gerald, and he is shown to be contended with a few predetermined, and constant repositories for his emotions - "his mother, country, dog, school, a friend or two, now - crowningly - Lois" (53). If he allots her a specific space in his practical 
arrangement of life, Lois wishes for "some incalculable shifting of perspectives" that would "bring him into focus". Gerald's unambiguous courting kills the romance she longs for: Lois thinks to herself, "if he would not love her so, give her air to grow in, not stifle her imagination" (71). It seems to be a foredoomed chemistry of opposing impulses. Gerald wishes to possess Lois, and contain her within his "generous allotment" of emotion: his idea of love is inextricable from his identity as soldier of Empire. It seeks to colonize, control and define the self-making of the female protagonist who is trying to mature on her own terms.

For Lois, the form of love that Gerald desires holds no charm. She has learnt that "love ... was the mainspring of woman's grievances. Illnesses all arose from it ... the regular practice of love involved a home; by money it was confined, propped and moulded" (83). The web of mundane duties that invariably arise from such a domesticated notion of love forms a sharp contrast to Lois' fantasy world. The latter is filled with the Morte d'Arthur and Omar Khayyám, a suggestive contrast in her and Gerald's literary tastes (139). Thus when Lois hears the Montmorencys talking about her on one occasion, trying to define her personality, she becomes outraged: "she was afraid suddenly. She had panic. She didn't want to know what she was, she couldn't bear it: knowledge of this would stop, seal, finish one." (83). Lois's reaction is the outrage of a youth and a woman without an immediate destiny. I would argue that it also captures the fate of the Anglo-Irish Ascendancy for whom the dynamic of development has historically ended.

As Jed Esty writes, “the belabored effort to sustain Lois' innocence ... corresponds to the belabored effort of the Ascendancy to enshrine their way of life as a permanent aspect of the Irish landscape" (183). The novel, I would argue though, is not sympathetic to either of these efforts of labor. The Last September underscores the impossibility of sustaining this specific 
version of Irish-ness. Even as she wants to "know" about the revolution, as noted earlier, Lois" rebellion against "knowing" herself is directed as much towards the Ascendancy as it is conditioned by it. It is important to note that in refusing to be identified by the senior members of the family, she also refuses the political mandates of her particular class. Released from the retrograde conventions of Ascendancy identity, Lois's youth must find a future beyond the narrative of Anglo-Ireland - and beyond the Big House itself.

Lois gets a new lease on life with the arrival of Marda Norton, one of Lord and Lady Naylors most notorious relatives, to Danielstown. Bold, outspoken and unflinchingly honest, Marda provides a model of independent womanhood that Lois finds fascinating. Marda, who is already past her "prime" at twenty-nine years old, is engaged to an English man named Leslie Lawe and is in the habit of frequently writing to him. As an engaged woman, Marda presents a hope for the future which Lois is unable to visualize for herself: "Lois thought how in Marda's bedroom, when she was married, there might be a dark blue carpet with a bloom on it like a grape" (141). Lois imagines that after her marriage Marda would forget all about her time at Danielstown. In a moment of weakness she hopes that, "instead of bleaching to dust on summers of empty sunshine, the carpet would burn with the house in a scarlet night to make one flaming call upon Marda's memory" (141). If the carpet crumbling to "dust" represents the degenerate state of Danielstown, the burning "flames" present an alternate if dangerously fraught possibility of renewal. The carpet along with the house would "burn" but also enjoy a fresh lease on life. In transcribing upon Marda her own future wishes, Lois unconsciously attempts to leave her mark.

At one point, Lois and Marda decide to explore a ruined mill some distance from the Big House. The mill emerges suddenly, "ghoulishly, round the bend of the valley" (178). As one of the many dead mills of the country, it is a symbol of an indigenous economy strangled by the 
colonial occupation, according to Hugo, at least. Little abandoned huts scattered around the mill reinforce the impression of a dead community whose livelihood was destroyed when the mill shut down. The mill presents the grotesque and gothic image of a corpse in the process of decay, "never quite stripped and whitened to skeleton's decency" (178). Looming over the beautiful countryside the mill acquires the "democracy of ghostliness" embodying the very spirit of decline. Even more than the decaying manor, and perhaps complementing it more fully, the mill represents the destruction of the past.

The mill inspires an unspeakable fear in Lois, who refuses Marda's suggestion that they enter the mill to investigate its interiors. Lois confesses to Marda that she often walks as close to the mill as possible but takes care never to go in. Marda's proposition has the ring of the forbidden, and for Lois it generates an excitement bordering on the sexual. On Marda's persuasion, she decides to step inside for a look. Inside the mill, Marda and Lois suddenly become aware of the presence of a man - possibly the escaped revolutionary - Peter Connor. Lying face down among the nettles, the man looks more vulnerable than threatening, causing Lois and Marda to feel guilty about encroaching upon his space. When a sound from Marda wakes him up the man immediately demands if anyone else is with them. He points a gun towards them. The women are alarmed at this "curious confrontation" but maintain their calm, with Marda confidently asking him to "go to sleep again" (181). The episode ends abruptly with Marda being wounded, conspicuously on her left hand, her engagement ring hand, by a gunshot fired from the man's pistol.

The scholar Anne Owens Weekes interprets the mill scene as a "pivotal" moment marking Lois's transition into womanhood (101). Lois can no longer be - if she ever was, in the first place - Eve in Edenic Anglo-Ireland, living a sheltered existence within the seedy, decaying 
Big House. Confronting the revolutionary in the discarded mill implies coming face-to-face with a reality that effectively, and deliberately destroys that Anglo-Irish Eden. As soon as they manage to escape, Lois and Marda decide that it would be best to keep the episode secret from the rest of the family.

It can be argued that the mill episode serves a primarily allegorical function in the novel. Bowen builds towards it from early on: with references to an escaped revolutionary that the English soldiers are looking for, the stranger walking down the garden path that Lois sees, and Lois's prior meeting with Peter Connor's family. The significance of these episodes now comes to fuller light. The shadowy figure(s) posit a different model of national subject-hood to Lois, one that she is afraid to acknowledge. Literally and symbolically inhabiting the periphery of the manor, Peter Connor presents a mode of masculinity that does not fit any of the models familiar to Lois. He is Lois's nemesis. Connor threatens to destroy her illusions about her cocooned existence within the Big House. It is due to her experience at the mill, particularly the witnessing of Connor's capacity to inflict bodily damage on Marda, that Lois is compelled to evaluate the security and complacence she may have felt as an inhabitant of the Big House. Moreover, Connor comes to exemplify, brutally, that the renewal of the mill - and by extension of Ireland is only possible at the hands of those who are enemies of the Big House.

With Marda's departure after this incident, attention turns once again to Lois' future with Gerald. Unable to conceptualize any other future except in marriage, Lois keeps assuring herself that she must marry Gerald. Her aunt, Lady Naylor, however encourages her to think of a career in art school. Writing to Marda about this conflict Lois is able, to her own surprise, to take an objective view of herself: "I have no future, in their sense. I have promised to marry Gerald" (258). The crucial part of this realization is the fact that her illusions of love have been 
dissipated. Marrying Gerald, Lois realizes, is a decision stemming from a sense of futurelessness rather than (and in fact in opposition to) love. Lois associates her power of analysis with a newly acquired maturity that helps her define Gerald: "he was a wood in which she counted from tree to tree - all hers - and knew the boundary wall right round" (259). The realization helps Lois to weigh Gerald objectively without a "pang of evocation", but it also reveals the changed parameters of Lois' relationship with him.

Lois' attempt at reconciling herself to her interests rather than emotions is nevertheless doomed, precisely by those who had attempted to guide her earlier, namely her family seniors. A confrontation between Lady Naylor and Gerald towards the end of the novel brings out the underlying anxieties about his marriage with Lois. Lady Naylor had earlier voiced her disapproval of the fact that Gerald, "seems to have no relations. One cannot trace him" (80). Now, she invokes the subject of his poverty. While this invokes a bitter but dignified resignation from Gerald, Lady Naylor reminds him that the "question of money" makes her apprehensive whether he could give the well-sheltered Lois what she is used to enjoying. The interaction is a tense one: Lady Naylor is "unusually nervous," she has "to tilt straight at indecency" to bring up "the question of money - a subject the English made free with, as free with as what was below their diaphragms, but from which her whole modesty shrank" (265). The passage explicitly illustrates the connection between the English-Irish divide and between money and sexuality: Lady Naylor is not only modest about money but also the sexual (reproductory) connotations thereof, both of which she imputes to the English.

This key episode, part of a section of the novel titled "The Departure of Gerald", highlights the uneven nature of the interaction between the two worlds of the Ascendancy AngloIrish and the English occupiers. As a representative of the old aristocracy, Lady Naylor 
challenges Gerald's smug confidence as a soldier of the occupying army. Not only does she establish Lois's superior class position relative to Gerald, she also dismantles his illusion about Lois' uncritical submission to him. Similarly, the episode brings about a reversal of Gerald's belief, earlier, that Lois would never understand what she meant to him, instead revealing his own misconceptions about her. Lady Naylor berates Gerald for his "lack of sympathy," and she proclaims, "You ought to be sensible" (265).

As an angry and disillusioned Gerald breaks off his engagement with Lois, she is heartbroken. This is the most poignant moment in the novel. Their last meeting takes place at the garden, the same place haunted earlier by the unnamed stranger figure. Lois is "mad" and “terrified" $(279,280)$. The twin aspects of Gerald's personality - his love for her and his unshakable faith in the British Empire - seemed to have offered her a refuge from her purposeless, fragile existence: "I thought you were a rock: I was safe with you" (281). Even in the emotionally charged episode of their break-up, however, Lois recognizes the unfathomable chasm in their understanding of each other. As she herself notes, "I didn't ask you to understand me: I was so happy. I was so safe" (281). Lois' repeated invocations of stability and solidity, despite the lack of actual "understanding" between them, poignantly captures this aspect of their soon-to-be-past affair.

In her haplessness, Lois presents a sharp contrast to her older, confident aunt, Lady Naylor. Mrs. Montmorency, who was the latter's peer (both had been presented to society together) recalls early in the novel that Lady Naylor was “"interesting', cultivated, sketched beautifully, knew about books and music. She had been to Germany, Italy, everywhere that one visits acquisitively" (14). Lady Naylor herself comments that the women of her generation were all rebels. This characterization is consistent with Lady Naylor's objection to Lois' marriage to 
Gerald. In envisioning a more independent path for her niece, who she wants to go to "art school", Lady Naylor reveals herself to be something of a feminist who does not believe in marriage as the only alternative for a young woman. In taking a firm stand on Lois' future, she plays the role of a guardian and an elder who can channelize the energies of the younger generation into productive directions. Yet this privileging of youthful female agency is disastrous for the Big House itself. ${ }^{8}$

Lois's broken engagement signals that the alliance between the (feminized) Anglo-Irish Ascendancy elite and the (masculinized) English nation can no longer be sustained. Like the postcolonial Irish nation, Lois' self-making is incomplete: however, a matrimonial union with Gerald would undoubtedly frustrate rather than catalyze that process. Her development as an individual corresponds directly to that of the nation, which can come-of-age only after breaking ties with the British Empire. The Last September gestures towards this analogy between the female protagonist and the nation. Lois thereby reclaims a new identity - no longer a member of the compromised Ascendancy, but as a national subject. Ireland at the cusp of Independence is similar to Lois standing at the threshold of innocence and experience, ready to move out of her insulated life within the Big House and into the larger world. Yet, the novel also suggests that this process of self-formation is inherently uncertain and uneven, as evidenced in Lois' lack of vision, certainty and direction. Her proposed solution to the problem, marriage, is doomed to fail from the very beginning, since it is based on a compromise of her independence.

\footnotetext{
${ }^{8}$ A historical figure that readily comes to mind in this context is Constance Markievicz, descendant of the Ascendancy who was a Sinn Fein leader and campaigner for socialist and feminist rights. She became the minister of labor in the Irish Republic. Lady Naylor shares that revolutionary feminist, but not nationalist and socialist ethos.
} 
With her aunt's encouragement, Lois leaves for her "tours" in France. A year after, three of the Big Houses, Danielstown, Castle Trent and Mount Isabel are "executed" by arsonists in the same night. The novel's use of the term, "execution," itself suggests the personification of the Big House. Bowen's description of the episode is deeply affecting, bringing out the paradox of her own position as an author recounting a personal and self-critical history. In a stroke of masterful irony, Bowen sets the destruction of Danielstown in the spring season, one that is usually associated with regeneration and rebirth. The episode converges in a tumultuous moment of the end of one social order for the birth of another one: "A fearful scarlet ate up the hard spring darkness; indeed, it seemed that an extra day unreckoned, had come to abortive birth so that these things might happen." (303, emphasis added) As the arsonists leave with the last remaining unscathed car, Sir Richard and Lady Naylor look upon the burning house silently.

The powerful, emotional and Gothic tone of the final passage of The Last September is unmistakable. The burning house, in brilliant contrast to the "spring darkness", is transmogrified into a giant funeral pyre that engulfs the entire landscape: "It seemed, looking from east to west at the sky tall with scarlet that the country itself was burning" (303). The repeated use of "scarlet" brings to mind Lois' earlier hope about the renewal of her life. She is notably, absent, from the scene. Only at the moment of its "execution" does the Big House become synonymous with - and in fact metonymic for - the "country". The arsonists' fire, intended to destroy the structure, burns the image of the ruin into the fabric of the nation, creating a permanent palimpsest of Ascendancy life that would survive through Irish literature as much as through cultural history.

In recent years, the Anglo-Irish Big House has been resurrected as a tourist magnet. Not only does this entail their physical restoration as the supposedly grand ruins of Irish history, it 
also requires the symbolic reinstatement, contrary to Bowen's novel, of structures explicitly associated with British colonial domination. It is with some sense of this irony that the critic Nuala C. Johnson describes the current Big House "heritage tourism" phenomenon as perpetuating Ireland's place as a "pleasure periphery" (191), comparable perhaps to postcolonial nations in the Global South. The paradoxical reconfiguration of the Big House, catering to the demands of metropolitan tourism, provides the immediate context for Molly Keane's novel, Good Behavior. If Bowen's depiction of a compromised Anglo-Irish Ascendancy provides a critical evaluation of the past, Keane's Good Behavior underscores the irony of, and rejects, its persistence in the present.

Published more than fifty years after Bowen's novel, Molly Keane's Good Behavior (1981) offers a similar yet markedly different treatment of the Big House, and the themes of marriage and female agency. Despite the Gothic style common to both novels, Keane's parodic tone stands in contrast to Bowen's far greater seriousness. ${ }^{9}$ Good Behavior opens with the death of the matriarch, the mother of the heroine Iris Aroon St Charles. In fact, this death is a carefully orchestrated murder by Aroon, who decides to serve an exquisite rabbit mousse dish to her

\footnotetext{
${ }^{9}$ Molly Keane was born Mary Nesta Skrine in county Kildare in 1904 into an Anglo-Irish gentry family. Her father was an estate owner and her mother Moira O' Neill, a poet. Keane initially wrote under the pseudonym M. J. Farell, changing it after her marriage to her husband Bobby Keane. As Farell, Keane captures the quirks and idiosyncrasies of the Ascendancy class in early novels such as The Knight of Cheerful Countenance (1926), Young Entry (1928), Taking Chances (1929), Mad Puppetstown (1931) and Devoted Ladies (1934). Later under the pseudonym of Molly Keane, she wrote several others such as Good Behavior (1981), Time after Time (1983) and Loving and Giving (1988). Keane also collaborated with John Perry on several plays early in her career, including Spring Meeting (1938) and Treasure Hunt (1950). Because of her prolific literary productivity, Keane has secured a niche as a significant writer not only within Irish but also global literature.
} 
anorexic mother fully knowing the consequences. Unmarried, unloved and lonely, Aroon St Charles is fifty-seven years of age at the beginning of the novel. The novel unfolds in the form of a mock-memoir, with the unconventional heroine relating the story of her childhood and adult life in the Big House of Temple Alice. Each episode, represented from Aroon's perspective takes on a tragi-comic mode, articulating and ruthlessly satirizing the Ascendancy class' preoccupation with "good behavior".

Keane's comic yet macabre Gothic plot is one of the outstanding features of the novel. As Ellen L. O’Brien comments, Keane's humor emerges from her "notorious use of excessive rot and decay": the source of "abjection" is located internally rather than externally within an embattled, self-destructive Anglo-Irish society (35). According to Vera Kreilkamp, Keane's major achievement is "to push the Big House form to its breaking point", dealing "a final blow to her own culture" (454). The black comedy of Good Behavior, according to another critic, is an enabling enterprise that allows the author to watch the disintegration of her world with ironic detachment (Lynch 74). Keane's parodic humor reconfigures the Big House genre, distinguishing and situating her work in an ironic affiliation to authors such as Bowen who critically represent the Big House within an organic if fraught community.

The Gothic plot in Good Behavior is reminiscent of J. Sheridan Le Fanu's Uncle Silas (1864) and All in the Dark (1866): in both authors' novels, "the punishment for Anglo-Irish [Ascendancy] guilt is visited upon its weakest descendants" (Kreilkamp 182). Keane directly adapts elements of the $19^{\text {th }}$ century Gothic tradition in Good Behavior. ${ }^{10}$ "Gull's Cry," the house

${ }^{10}$ As a historically troubled English colony, Ireland particularly in the revolutionary period of the late $18^{\text {th }}$ century becomes a repository for English anxieties about savagery and wildness. This perception exists side by side and in fact reinforces the other colonial stereotype, of a quaint, rural Irish timelessness compared to a rapidly industrializing England. A good example 
where the murder takes place, "is built on the edge of a cliff. Its windows lean out over the deep anchorage ... [a] Gothic folly of a house" (4). Later in the novel, major characters hide away secrets, suffer horrible accidents, and are driven to commit suicide. The heroine, Aroon, is not only a cold-blooded murderer; she exhibits an extreme attachment to power, turning out her sickly relatives, "put[ting] the two of them in hospital wards, male and female, to die on their own alone" (4), and usurps their home (4). She is a feudal mistress par excellence. Almost a modern-day Dracula, Aroon too displays a voracious, vampiric appetite. A constant supply of food is central to her existence. Through her representation of Aroon, Keane reconfigures the gendered codes of the Dracula story. But Aroon's femininity shares none of the sexualized, nurturing qualities of the protagonists of a Jane Austen or a Charlotte Bronte. ${ }^{11}$

Keane's parodic tone also aligns the novel closely with the Anglo-Irish comedy of manners (Lynch). However, under the clever patina of comic moments and caricatures lies a portrayal of a world marked by devastating cruelties and inequities. Through Aroon's reminiscences about Temple Alice, we learn that in that Big House, pet dogs are fed chicken while the servants live on "Robin starch from the laundry" (45). Overdue bills from the butcher and the local wine-merchant are stuffed away quietly into drawers, while the matriarch continues of this dual attitude articulating a "colonial Gothic" (Nordius 2002) is to be found in Sophia Lee's 1783-85 novel, The Recess that fictionalizes the Elizabethan Irish wars using prejudicial notions developed in the $17^{\text {th }}$ and $18^{\text {th }}$ centuries in England. For more on the Irish articulation of the Gothic, see Foster 2006, Killeen 2014.

${ }^{11}$ The resonances of Good Behavior to Bram Stoker's novel are not accidental. There is a significant element of Irish literary history in the gendered representation of Gothic romance. The Irish novelist Sydney Owenson's The Wild Irish Girl (1806), published shortly after the Act of Union of 1800, draws on the tropes of decaying Celtic nobility to present a love story between Glorvina, daughter of an Irish nobleman and the eponymous "wild girl" of the novel's title, and Horatio, the bohemian scion of an English aristocratic family. Nearly a hundred years later, Bram Stoker, author of Dracula, would invoke the same exotic and gendered image of Ireland in his 1890 novel The Snake's Pass. Stoker's hero Arthur Severn stumbles across the west of Ireland, a landscape marked by with its wild and dangerous "mass of violet and silver and gold" (Killeen 8). 
to buy old "French" and "Regency" furniture, "considered both ugly and worthless by her contemporaries" (66), for decorating the house. The time period of this particular passage is significant: it is 1914, the First World War is underway, and the Easter Uprising of 1916 is two years away. While Aroon's father goes away to serve in the war, her mother's "greatest pleasure and distraction at that time was buying junk furniture." (66) The furniture of the Big House contributes to a double dissimulation, on one hand helping to hide the shame of unpaid debts, and on the other hand highlighting Temple Alice's false sense of grandeur (with the aid of "varnish removers and oil mixtures"). ${ }^{12}$ The humorous portrayal of such episodes reveals the incongruity between socio-economic reality and the response of the manor's inhabitants. It highlights, surely, the pitiable condition of the Ascendancy elite.

The novel's opening, which reveals Aroon as a cold-blooded murderer, is one such move that alienates the reader from any sympathetic identification with the heroine. Paradoxically, it is the act of murder that allows Aroon to narrate the story of her childhood and young adulthood in Temple Alice. Aroon clarifies the significance of the title by explaining what "good behavior" stands for: she defines it as "the punctual observance of the usual importances", similar to what she has followed all her life: "I do know how to behave ... I have always known" (9). The vagueness of the definition serves to underscore its hollowness.

Aroon's family, the venerable St Charles', illustrates the emptiness of the codes of "good behavior" by observing them only in their violation. As Aroon starts narrating her childhood in Temple Alice, the novel introduces her family members -- selfish, hypocritical, and highly snobbish without exception. Her father is affectionate but ineffectual, a serial philanderer; her

${ }^{12}$ Good Behavior repeats the ironic reference to useless furniture that is found in Edith Somerville's The Big House of Inver (1925). There, an illegitimate offspring of the Invers fills up the Big House with Victorian-era gaudy furniture, only for it to be destroyed in the end. 
mother is cold and distant, occupied with her "ugly" furniture and painting; her brother, Hubert, is a closet homosexual and self-obsessed. Even the grandfather is not spared; the reader learns that Temple Alice had a perpetual paucity of water because Aroon's grandfather "had deflected a considerable quantity of it to a pond on which ... he loved to row himself about" (12). The family's pursuit of leisure activities, such as horse riding, painting, buying antique furniture, rowing, etc., and lack of engagement with material realities, underscores their disconnect. As well, it foregrounds and highlights the tendency to construct elaborate myths about their sophisticated manners -- "good behavior", in other words.

Keane emphasizes that such mythmaking has a particularly pernicious effect on the women in the novel. This is somewhat true for Mrs. St Charles, who wastes her effort (and the family's money) in useless pursuits; but it is the figure of Mrs. Brock, Aroon and Hubert's devoted governess, who occupies an important position in the first part of the novel, who illustrates it much more sharply. Mrs. Stock comes to Temple Alice straight from an English Big House, Stoke Charity, owned by the family friend, Wobbly Massingham. She serves a dual purpose: on one hand, she is the substitute maternal figure, providing the children Aroon and Hubert with better food, and a cleaner nursery that their mother does not care about. On the other hand, she tells Aroon and Hubert "stories" about Stoke Charity and its residents, including the house's heir, Richard.

This is particularly significant since later on in the novel Richard appears as a principal, and thwarted love interest for both Aroon and Hubert. As the narrator, Aroon highlights Mrs. Brock's role in forming this interest when she notes, "she was to be my first intimate link with [Richard]" (19). Mrs. Brock's influence is borne out in Aroon's obsession with the thought of becoming Richard's wife well until she is past her prime. Not only that, Mrs. Brock's stories 
about Richard's house, the "luxurious and easy atmosphere" at Stoke Charity (47) generates a longing for stability and prosperity in Aroon. It is through Richard and his estate, and the notion of a mythical "Englishness" perpetuated by Mrs. Brock that the child Aroon compensates for her dysfunctional family.

Equally, Mrs. Brock is a victim of her own illusions. At Stoke Charity, she develops an intimate bond with the child Richard, and an even stranger fascination for Richard's mother, Lady Grizel. Her dismissal from Stoke Charity is the direct result of her supposedly bad influence on Richard, who takes to "reading poetry when he ought to be getting his pony ready", and who "forgot all the stiff-upper-lipmanship", "all proper rules" (33) suitable for conduct. Mrs. Brock is out of line in that house: where "everything ... belonged to a different and more glorious race from [her] ... The house contained different worlds, each designed for its particular occupants: owners, guests ... a proper setting and place for each and everyone" (34, 38-39, emphasis added). After indulging the child in such unmanly activities as poetry (rather than ponies), Mrs. Brock commits a final act of transgression when sets out, in the dead of night, to visit Lady Grizel's room to say goodbye to her. The latter is stunned, "as repelled and alarmed as she might have done at the approaches of an unwelcome love" (41). The irony of the sexual reference is heightened by the fact that, just a moment prior Lady Grizel is shown sleeping in the bed with her two dogs, "all three enjoying a delightful night's companionship" (40), which only took place in her husband's absence since he disapproved of dogs in bed. For the assembled human and non-human company in the bedroom, the intrusion of Mrs. Brock is symbolized when the dogs "bark" at her repeatedly.

After she leaves Stoke Charity to arrive at Temple Alice - a punitive transfer from England to Ireland - Mrs. Brock, once again, commits dangerous (and this time, fatal) 
transgression. She becomes enamored of the narrator's father, Major St Charles and possibly even has a sexual liaison with him. The narrative is vague on this subject, operating instead through suggestion. In a telling scene, when Aroon and Mrs. Brock talk about the breeding of animals, Mrs. Brock unexpectedly uses the conversation to tell the child about male sexuality: "It's a thing men do, it's all they want to do, and you won't like it." (62). This cryptic warning has the suggestion of sexual desecration. Without being explicit, it conveys the idea that Mrs. Brock may be referring to her own violation at the hands of her employer. Paradoxically, it is the child Aroon who unwittingly contributes to Mrs. Brock's situation by telling her about her father, only partially aware of the feelings she was generating in her governess: "She listened to me with close attention ... tense with pleasure ... while I glowed in its bestowal" (50). Both Aroon and Mrs. Brock tell fanciful stories to each other. The reciprocal act of storytelling draws a parallel between the female child and the adult woman both of whom, despite their class difference, are equally disempowered and delegitimized by the structure of Ascendancy life. ${ }^{13}$

I would argue that Mrs. Brock provides a narrative prefiguration of the fate that befalls the heroine Aroon later in the novel, namely the frustration of female sexual and social desire that does not know its place. But their class positions prevent any genuine sympathy and female bonding: Aroon leaves her, saying, “'Papa's waiting for us,' I excused myself ... I knew I was deserting her when she seemed to need me, as I had longed for her to need me, but I felt

${ }^{13}$ The substantial section devoted to Mrs. Brock in Good Behavior signals towards a lesserknown sub-genre of Victorian fiction - the governess novel. Keane adapts earlier models of the Governess novel, such as Anne Brontë's Agnes Grey (1847), Charlotte Brontë's Jane Eyre (1847), and the Irish author Kate O'Brien's controversial Mary Lavelle (1936). In these and other works, the figure of the governess is used as a register of class and gender hierarchies (Lecaros 2001). The experiences of the middle-class governess are counterpoised against the immoralities, decadence and instability of the manor house or country house. In some cases the governess engages in detective work, uncovering carefully guarded family secrets and ignominious histories. Keane uses a mock version of this theme in Mrs. Brock's farcical investigation into the disappearance of Lady Grizel's engagement ring. 
frightened of her" (62). As Aroon goes to her father, Mrs. Brock leaves the house, only to surface a few days later, dead by drowning. In keeping with the novel's overall tone, the description of her suicide is cryptic, "It was some time before they found her body, swollen almost to bursting the frilled bathing costume" (64). Aroon is sent off to boarding school soon thereafter, and her family life breaks up even further with the onset of war.

One of the early signs of dysfunction within her natal family lies in the relationship between Aroon's parents, Mr. and Mrs. St Charles. After Mrs. Brock's death, the parents come to the foreground of Aroon's narrative. In the absence of any real emotional compatibility, what holds their marriage together is the shared compulsion of maintaining social decorum. As the narrator observes, "they never had much to say to each other. He had no more understanding of her painting or gardening than she had of horses or fishing or shooting" (11). The St Charles' are never shown having any substantial conversation. The scenes where they do engage in dialogue are, strategically, placed beyond the diagesis: either conducted in privacy in the narrator's absence, or cut short abruptly as she walks in. The reader, like Aroon, is never allowed into the private realm of their marriage but must depend on Aroon's narrative to speculate on their relationship.

Aroon's father, Major St Charles does share something of a relationship with his daughter, both loving and dominating her. The patriarchal validation that Aroon so desperately seeks comes chiefly from him. "We adored Papa, and his hopeless disapproval paralyzed any scrap of confidence or pleasure we had ever had in ourselves or our ponies." (54) "The Major", as he is lovingly called, is first introduced as a hard taskmaster, "incomprehensible, impatient, and unnerving", who instructs his children in horse riding, and then as a handicapped War veteran who is completely dependent on them. Such drastic role-reversal, which takes place once 
Major St Charles returns from the First World War with an amputated leg, significantly compromises his authority as well as influence over the family, engaging his wife and daughter in a complex power struggle to keep the household running.

The Major's disability, however, does not cause any impediment in the pursuit of his interests -- horses and women. Having emerged as a hero and a martyr, he finds easy access to army clubs and obliging ladies, moving further away from his duties as patriarch. Blissfully oblivious to his family's depleting resources, the Major continues "hunting, fishing and shooting in their proper seasons, at Temple Alice" (73). At the same time he holds complete sway over Aroon, secretly hoping to see her married to his English friend Wobbly Massingham's son, Richard.

Aroon's friendship with Richard is largely mediated through her brother, Hubert. Hubert encourages his sister to believe that Richard is in love with her, even compelling her to let him into her bedroom. Aroon fails to realize that this is in fact an elaborate ploy, meant to detract attention from Hubert and Richard's forbidden homoerotic friendship. Aroon's longing to be accepted and validated as an object of desire propels her to create and sustain the fantasy of becoming Richard's wife. Aroon thus compounds Hubert's deception of the family, in a complex and tragic comedy of manners that dismantles every code of "good behavior".

With his distinguished physical appearance and family background, Richard reminds Aroon of the young men who had "paralyzed me into the maintenance of a silence": he appears to her, "straight from the middle pages of the Tatler and Bystander. The right family, the right 
school, the right regiment had all been his." ${ }^{, 14}$ During their meeting at the dinner party, arranged by Hubert, Aroon is rendered overwhelmingly self-consciousness. "I was stunned between fear and admiration", she notes, anxious about Richard's reaction to "my company, my size and my countrified simplicity" (85). Aroon's apprehensions about Richard prove true when both he and Hubert reduce her to a "happy joke". Aroon's response is strange if in keeping with her abject state of mind. Not only does she accept her own objectification, she decides to take it to another level by deliberately overeating: "I can be the fat woman in the fairground ... the pigheaded woman; anything to escape from hopeless me". Such self-degradation does not gain the protagonist any sympathy, but it does highlight a quiet rebelliousness, a refusal to be victimized by the men. Aroon diffuses their "joke" by laughing at herself thereby proclaiming her own individuality: she claims -- "I was a person again" (85).

Aroon eventually secures a place in the friendship between Hubert and Richard. However, it remains a tenuous position. In a telling episode when she is allowed entry into Hubert and Richard's moment of privacy, Aroon cannot see the palpable, sexually charged intimacy between them. She finds Richard "in his dark dressing gown, lighting a cigarette, glaring at himself in the square, mahogany-framed looking-glass", while Hubert sat on the bed "wrapped in one of those great rough bath towels, sampler-stitched in red" (95). The erotic suggestiveness of the setting is lost upon Aroon, who invariably overstays her welcome until Hubert bluntly asks her to leave. When she is outside the door, she hears "laughter that expressed their relief from some tension" (96). Aroon feels, correctly that this rejection puts her back in her abject place as "daughter of the house, unmarried daughter" (96): the episode forecloses any

\footnotetext{
${ }^{14}$ The Tatler is a British magazine started in 1901 by Clement Shorter. It covers the lifestyle and scandals of British upper-class society. In 1940 it absorbed the Bystander magazine and became the Tatler and Bystander. Since the action in this episode is set before 1940, that is why Aroon refers to the magazines separately, as they existed before their union.
} 
possibility of a normative, heterosexual union between Aroon and Richard. However, it also becomes necessary for the "lovers", Hubert and Richard to convince Aroon of the exact opposite.

In order to deflect suspicion from the truth of their forbidden relationship, Hubert and Richard use Aroon as a buffer. Hubert, who is well aware of the Major's desire to see Aroon married to Richard, tells his sister that Richard wants to see her "in bed" (101). There is much at stake in this elaborate charade, concocted to convince the Major that Richard and Aroon are lovers and may soon be married. Richard's coming to Aroon's room at night constitutes a violation of the codes of proper behavior, but it is a form of violation that is quietly "legitimized" under a patriarchal system. In fact, Hubert counts on his father coming to know about this act of transgression, which is undertaken precisely to cover the larger sexual transgression posed by homosexual love. Richard of course has no plans of making love to Aroon, and he departs after spending some time in her company, leaving her alone in a sea of "anger and anxiety" (108).

Hubert and Richard's joint deception not only illuminates the gendered boundaries that define "good behavior", it also subjugates Aroon's desire to that of the male heir, Hubert. The incident forestalls the possibility of her marriage. While waiting for Richard, Aroon is filled a hitherto unknown confidence and self love: "Leaning towards my glorified eyes in the mirror I could have kissed my image ... Quite literally, my appearance took my own breath away" (105). For the reader who can already anticipate that Richard will reject her, Aroon's self-image heightens the irony of the situation. It is reinforced even more forcefully when Richard rejects Aroon on the grounds of "good behavior". He slyly tells her, "I really must NOT touch you" (107). There is a double subjugation in the episode. First Aroon's sexuality is denied so that Hubert's (and by association Richard's) may be sustained without any hindrance. Second, 
Aroon's individuality is denied because she is the daughter who must carry the burden of good behavior so that the son does not have to.

The episode underpins the darker side of Keane's humor, which uncovers the deeply unequal and exploitative gender codes of the Ascendancy. Aroon's elaborate self-delusion helps her to survive her victimization, but it also illustrates the hypocrisy and immorality of the family. Every "victory" of Aroon is at the same time a conspicuous statement of loss and defeat. Reflecting on Richard's "chivalry", Aroon convinces herself that they "had behaved beautifully". In real terms, however, this is a revelation of her self-pity. Falsely, she notes to herself that, "I can never look on myself [any more] as a deprived, inexperienced girl. I've had a man in my bed. I suppose I could say I've had a lover" (108). Richard's promotion from being a man to "a lover" signifies the blatant mythmaking that enables Aroon to survive her loss. In the absence of any concrete promises on Richard's part, it is up to Aroon to create a fantasy vision of a future that would help her to carry on performing the code of "good behavior".

Suddenly, Hubert dies in a car crash. This tragic news is received pithily in the St Charles household; Aroon's Papa reads the telegram in a "perfectly ordinary voice" which changes midsentence to "embarrassed importance", and Mummie "laughs hysterically" (111). But the strangest reaction is from Aroon. Recovering from the initial shock of the news, Aroon's first coherent thought is that Hubert's death presents an opportunity for her. "In the stillness of my shock there was only one reality: Richard was alive. A shiver of expectation went through me: Hubert's death must link us more closely" (111). This is more than a crude display of an exaggerated selfishness. Not only does Aroon demonstrate no sentimentality, she also plans on building the future previously denied to her, literally on her brother's grave. The thought occurs to her within the same passage, "They brought him from the station to Temple Alice church ... I 
would be married there naturally" (111). This is a suggestive transition. It indicates Aroon's symbolic reclaiming of a desire that Hubert had appropriated from her. By giving the reader access to her thoughts in the stream-of-consciousness mode, Aroon publicizes what her parents would call a "private" expression of grief. The church itself is "stark little [and] Protestant ... endowed long ago by the family": it is "chill and stuffy, and dead birds usually lay about in the aisle", "visited only for funerals and christenings and weddings" (111-12). Such a drastic projection of the private into the public reveals the code of "good behavior" for what it truly is, an external façade to hide inner thought.

Hubert's wake follows the same pattern: "there was to be no sentimentality", since "it was the worst kind of bad manners to mourn and grovel in grief" (115). This obsession with good behavior surfaces in her parents' lack of a public display of emotion, and the rest of the congregation which whispers politely about "cub-hunting and racing, honey bees or the price of oats" (112). Aroon's parents adhere to appropriate conduct: "Papa and Mummie stood together, as close as possible without actually touching each other". Her mother, who according to Aroon looks "wonderfully distant from it all", had donned "a fine black felt hat ... as suitable for a racemeeting ... as for a funeral." (112) Instead of providing emotional support to each other, the family deals with their bereavement by competing to put up their best behavior: "We exchanged cool, warning looks - which of us could behave best: which of us could be the least embarrassing to the others" (113). The scene highlights the sense of entrapment that social decorum creates for the characters, even as it mocks their attachment to moral codes that have already become antiquated.

Hubert's death brings about a massive transformation. It is the breaking point beyond which the codes of morality and decorum gradually disintegrate. Shifting the focus away from 
the romance plot, Keane recasts attention on structural fractures within the household, so that its decline may be charted. The car breaks down gradually due to lack of repairs, and the bills of grocers and wine merchants begin to mount. Revealingly, "the dogs felt the change in their lives" (147), and are no longer fed sumptuous amounts of chicken. Mummie continues to live in denial of the steady depletion of the family resources, retreating even further into her private, insulated artist's world. The situation goes from bad to worse, when Aroon's father falls seriously ill due to his heavy drinking habits and they have to hire a nurse to look after his needs. But even as Aroon and her mother watch helplessly, the nurse begins to mistreat the Major as a revenge for not being paid. Eventually it is Aroon who must take charge of the situation. She bravely sells her horse, gifted to her by Richard as a "present" -- "a solid testimony to my love, our love, growing" (157) -- pays off the vindictive nurse and attempts to save the family.

At the same time, a complex power struggle develops between Aroon and her mother. Mrs. St Charles' idea of economy, as Aroon observes, is based on the principle of "penance” for others. Even as she continues her expensive investment in furniture, buying a "side table" which she describes as a "coup" (157), Mrs. St Charles brings about some very quick and undesirable changes: "The fires and stoves went out. Maids were sacked. Food became impossible.” (181) The last poses a particularly horrifying prospect for Aroon who has an excessive appetite. Mrs. St Charles, already upset with Aroon for taking the upper hand, reminds her of her place in the most insulting way possible: "Perhaps if you were willing to eat just a little less, we wouldn't have this appalling bill; of course you happen to be a big girl" (178). Just as her appetite had earlier turned Aroon into a crowning joke for Hubert and Richard, for her mother Aroon presents an embodiment of excess. 
The tumultuous relationship between mothers and daughters in Irish fiction, as the critic Anne Fogarty writes, signifies the "unstable operations of power in a colonial culture" (86). Aroon's relationship to her mother is frustrated by the latter's detachment and even active hostility to the female child. She has a negative influence over Aroon's development, crushing her spirit with brutal honesty and taunting her about her appetite and physical bulk. Exploring this problematic mother-daughter relationship allows the novel to explore the impossible trajectory of female development that is frustrated at the very outset. Rejection from her mother propels Aroon to search for male validation, thus pushing her further into the depths of a psychological disempowerment and perversity.

Aroon's disadvantages vis-à-vis the marriage market become evident during a local Hunt ball. This was the only form of celebration that Aroon could look forward to that year, as the family could not afford to celebrate Christmas at Temple Alice. As the economic realities become apparent the family tries to keep "our heads above the morass", stifling "screaming despairs only by the exercise of Good Behavior" (191). The emphasis here is suggestive. It indicates that by this point in the narrative "good behavior" has become a state of being - the only means of making sense of an uncertain social existence. The contrast between the cold, "draughtless" and "unused" inner area of the house and its "black" "frozen" luxury objects, and the hopeful protagonist is suggestive: "I snatched up the small black gramophone, frozen all these months to the top of the grand piano. I had decided to practise my dancing before the ball; at least that would warm me and occupy time" (192).

At the ball, Aroon is painfully reminded of her marginal status. She receives attention from crude, unbearably patronizing elderly men who have no sympathy for her, only a chauvinistic condescension. To make matters worse, she has to accept a ride from the petit 
bourgeois solicitor, Mr. Kierly who takes the opportunity to make a proposal. Aroon, proud and aware of her identity as the daughter of the Big House, promptly refuses him. The episode illuminates the crisis of the unmarried woman in an increasingly alien world. The figure of the solicitor as a potential suitor for Aroon is, at least for her, more of an insult than a compliment. Such a union would have secured her a respectable life of middle-class gentility, but it would be a violation of good behavior - a transgression of the boundaries that define her identity. The situation invokes yet another instance of Keane's brilliant comic irony. The suitor has "the wrong kind of voice", wears a "dreadful" scarf, and Aroon "cringes" in his presence. (209-10). Aroon rejects Mr. Kiely with an exact simulation of her mother's tone: "One of Mummie's phrases came to me and I spoke it in her voice: 'You must be out of your mind,' I said, and knocked his hand away. In spite of my heartbreak and tears, I was after all, Aroon St Charles" (211). ${ }^{15}$ As the mock-tragic heroine, Aroon must play this part to perfection so that the degeneration of the big house becomes inevitable. The seamless continuity between Aroon's fate and that of Temple Alice is underscored as Mr. Kiely leaves her at her house, "In the cold of the hall I loomed to myself, a great creature within limitless suffering" (211).

Her experience leaves Aroon in a state of extreme self-abnegation, allowing her to see through the illusions that have sustained her all her life. At the ball, prior to Mr. Kiely's proposal, Aroon comes to know of her betrayal at the hands of Richard. She reads, ironically in the Tatler, the news of Richard's engagement with a Miss. Alice Brownrigg. Remembering what she had hoped to be, "the easy ardent girl ... intent for the moment on horses and the calm young woman sitting by water with two glorious children" (210), Aroon breaks down with the

${ }^{15}$ While Aroon invokes her mother, the person she does not invoke is equally significant. Early in the novel, when Mrs. Brock professes "her love" for her employer Lady Grizel, the latter claims with shock, "Mrs. Brock - have you gone out of own mind?" (41) Aroon places Mr. Kiely in the same subordinate position that her beloved governess had been placed in earlier. 
overwhelming feeling of being lost. It is in the Tatter she can, finally, see herself realistically as a woman out of place: "A full- page picture changed all the fugitive glamour ... to a quiet contemplation of marriage and motherhood as understood by the proper sort of English family ... Melted far in the distance, beyond lawns and terraces, the Palladian façade of a great house filled in the picture" (206, my emphasis). It is a tragic moment combining the loss of marriage with that of the "English" "great house", a moment of anagnorisis as the protagonist stands face to face with the truth. The "full-page picture" in "The Tatler", I argue in more detail below, is a metaphor for contemporary, that is 1970 s and 80 s, attempts at constructing a mythical tradition for Ireland in line with the "West". But it is also the moment before the drastic turn of fate that is to bestow Aroon with the ownership of Temple Alice.

Aroon's "victory" comes after her father's death. Believing her daughter to be entirely at her mercy, Mrs. St Charles falsely accuses her of being responsible for the Major's death. Aroon now imagines a future under the domination of her unfeeling mother, with the faithful maid Rose to whet her authority. She knows that, "Mummie and Rose would be in power over me, over Temple Alice, until I was old, or middle-aged at best ... They may starve me too - the idea filled me with panic" (219). In the absence of a marital family, Aroon realizes she would have to alter the power dynamics in her natal family in order to survive.

The opportunity comes about when it is revealed, during the reading of her father's will that the Major had left Temple Alice and the bulk of his remaining assets to his daughter Aroon. This event takes place in the last few pages of the novel. The revelation immediately alters Aroon's outlook from victim to victor. This turn is parodic of course, since there is no actual redemption for people like her, but nevertheless Aroon claims, "the face of the old world turned away from me - a globe revolving - I was looking into a changed world, where I was a changed 
person." (243) She realizes, "I was claiming what was mine ... my love was recognized and requited" (243). The will gives a legitimate space to the daughter within the family chronicle allowing her to articulate her own history.

The father's gift to the daughter is also based on an ironic appropriation of power from the actual owner of the house, Aroon's mother, who had signed away her rights to her husband five years prior to his death. In the discourse of legality, Aroon derives legitimacy from her father's will: the irony, however, lies in the fact that the house belonged originally to Mrs. St Charles' family, and is not his to "gift" in the first place. Mrs. St Charles points this out during the reading but the power of male "will", articulated in the father's legal will and reinforced by the solicitor (Mr. Kierly), negates her claim. Such a problematic ending, as Rachel Jane Lynch points out, necessarily engenders "mixed feelings" (83). The "gift" is bestowed on a woman, Aroon, who subjugates herself to male power, thrives on male validation and is dependent upon male legacy. Aroon's father's gift to her is thus symbolically a double-edged- sword. It provides legitimacy to the unloved daughter, but in doing so also compels her to remain within the "patronymic design" of the Ascendancy big house (Grubgeld xi). Her survival at the end of the novel symbolizes a fruitless return to a feudal-colonial social formation.

The novel Good Behavior appears at a historical moment, 1981, when the Big House is freshly reconfigured and reinscribed as a symbol of nostalgic Irishness. Accomplished by the rise of heritage tourism, such symbolism is tied to what Nuala C. Johnson calls the effort to "sanitize the past": the Big House is no longer the signifier of an elite Anglo-Irish Ascendancy, a suspect marker of cultural refinement at odds with Irish nationalist championing of the rural. Instead, it becomes an ideological construct, reflecting the intersection of a postcolonial claim to civilizational heritage, the obfuscation of material inequalities and stagnation, and the projection 
of a cultural-political desire to join ranks with the frontline of the "West". As Johnson (1999) among many others points out, Big House heritage tourism coalesces in the context of global neoliberal restructuring. It serves to promote an Irish economy devastated by the European Union- and world-wide oil crisis of 1973 . Backed by the state, heritage tourism aims at generating low-level service-sector jobs while simultaneously driving up corporate profits. In this, Ireland is similar to other "pleasure peripheries" in the postcolonial world, commoditized for Western European and North American consumption. At the same time, Ireland's location within the West, and its physical proximity to Great Britain, puts it in a peculiar relation of postcoloniality to its former colonial masters.

I would argue that Good Behavior directly responds to and critiques the contemporary repackaging of the Big House. In its depiction of events of the interwar period, the novel is simultaneously alert to its contemporary moment. When Aroon claims that, "the face of the old world turned away from me - a globe revolving - I was looking into a changed world" (243), this is a crucial moment when the novel directly gestures to historical shifts, illuminating the tensions and erasures inherent in the practices of a changing world. Similarly, when Aroon imagines herself as an English lady of the manor, seeing her likeness in the "full-page picture" in The Tatler, her self-image parodies the glossy tourist brochures of a reinvented Ireland. She mistakenly sees herself as Richard's bride, after his marriage to "Miss Alice Brownrigg" had already happened. Aroon is both an empty figure, awaiting fulfillment through marriage with the Englishman, Richard, and a latecomer to the same event. In this she parallels not only the Big House but also Ireland itself. "Tourist brochures suggest that Ireland offers the promise of 'empty space' - space that is uninhabited ... [and] similarly conveys Ireland as occupying 'empty time' — where today is like yesterday and yesterday is like tomorrow ... Tourist images 
and travel writing about Ireland have adopted ... representational practices where Ireland is placed 'behind' modern time" (Johnson 191-192). Aroon commits murder in the course of her deluded search for self-identity. In deploying the themes of parodic self-aggrandizement and the protagonist committing murder in search of fulfillment, Good Behavior, remarkably, parallels another postcolonial novel of recent times, Aravind Adiga's acclaimed The White Tiger (2008). Like Adiga's novel set in a changing India, Keane's novel serves as a critique of postcolonial ambition, consumption, and excess and their ideological imbrication with global neoliberalism. ${ }^{16}$

Such a contemporary inflection also distinguishes Good Behavior from Bowen's earlier novel The Last September. Written in the aftermath of the formation of the Irish Free State in 1922, Bowen's 1929 novel suggests that the decadent Big House is destroyed by the incursion of a nationalism that is progressive, and external to it. Both the destruction of the house and the heroine Lois' self-dissociation from it, the novel seems to suggest, are necessary to open up space for a nationalist, postcolonial utopia, howsoever inchoate, tentative and uncertain. There is no such externality or progression in Good Behavior; the neoliberal version of the nation appropriates the Big House and its history for and within itself. In this latter-day version, the commoditized Big House, its inhabitants, and the postcolonial Irish nation are the one and the same. Therefore, the novel's critique is an internal one, highlighting the contradictions that connect all three entities.

${ }^{16}$ The White Tiger parodies the ideological construction of contemporary India as a major economic power, and with China, as a competitor of the "West". The protagonist Balram Halwai is a low-caste working class man from the countryside, who becomes a successful entrepreneur after killing his employer and stealing the latter's money. The novel underscores the deep inequalities in a class- and caste-ridden Indian society, even as the protagonist joins the global ranks of the entrepreneurial West. 
This is most keenly felt, I have argued, in the contrasting articulation of "marriage" in the two novels. Lois feels the urge to know herself beyond the narrative of marriage, as well as the gendered codes of behavior in Danielstown, and is assisted in that onward movement by her elder female relative, Lady Naylor. On the other hand, Aroon relies on fantastic stories (such as those by her governess, Mrs. Brock) that only try to connect the Big House of Temple Alice to the elusive English manor of Stoke Charity. In order to interrogate this ideology of gendered story telling, Good Behavior parodically adapts elements of earlier Big House fiction, where "the ever-receding ideal of the cultivated Big House at the center of an organic community is based on a fictive rather than historical vision of the past" (Kreilkamp 453). Aroon is a parodic version of Charlotte Mullen, protagonist of Somerville and Ross's The Real Charlotte (1894) who struggles to overcome her lack of physical beauty and class status in order to be married to the man of her choice. Similarly, the Gothic as well as "rescue" tropes of earlier Big House fiction are reconfigured in an exaggerated version, in Aroon, her family members, as well as Temple Alice. Such adaptations underscore the feudal-colonial aspect of the Anglo-Irish past, and interrogate their reemergence in the present moment. 


\section{CHAPTER THREE}

\section{YOUTH AND THE BILDUNGSROMAN}

\section{IN MAHASWETA DEVI'S MOTHER OF 1084 AND JENNIFER JOHNSTON'S}

\section{SHADOWS ON OUR SKIN}

In the world-system's peripheries, existing in an asymmetrical relationship with the core capitalist centers, modernity is invariably experienced as a deeply uneven process. Such unevenness manifests itself as some demographics in the periphery gain social mobility, and others do not. The literature that emerges out of peripheral contexts must engage, as a result, not only with structural underdevelopment in its immediate locale, but also with the inflections of an unequal world-system ${ }^{1}$. This shared experience of an uneven modernity is reflected most prominently, I submit, in formulations of the peripheral Bildungsroman. Because the protagonist inhabiting peripheral spaces must necessarily navigate this unevenness in their "coming-of-age", the developmental paradigm of the traditional Bildung is no longer viable. It must be replaced, as Jed Esty (2012) observes, with narratives where the promise of socialization is stalled or remains incomplete.

\footnotetext{
${ }^{1}$ My use of these concepts is derived from Immanuel Wallerstein's model of the modern world system as divided into the "core", the "semi-periphery" and the "periphery", on the basis of a geographical division of labor and trade. See The Modern World-System: Capitalist Agriculture and the Origins of the European World-Economy in the Sixteenth Century. New York and London: Academic Press, 1974. In Wallerstein's formulation, nation states exist in a deeply unequal and asymmetrical relationship to each other within the rubric of a modern, capitalist world-system. The semi-peripheries and peripheries are economically backward and structurally underdeveloped, because of this unequal relationship to the industrially advanced, core-capitalist states. Wallerstein derives his theory of combined and uneven development from Leon Trotsky's earlier theorization in The History of the Russian Revolution (1930) on the peculiar social structures of economically backward spaces. Recent scholarship has revived Wallerstein's theory in the field of literary studies, particularly discussions on world literature (Deckard et al 2015, Casanova 2007).
} 
In this chapter I examine Mahasweta Devi’s Mother of 1084 (1974; trans. 1997) and Jennifer Johnston's Shadows on Our Skin (1977), as literary instances of the distorted Bildungsroman of the periphery. National self-determination converges in these novels with the trajectory of the protagonist's character-formation. This process uncovers a fundamental distortion in the very idea of "coming-of-age" under the aegis of decolonization. The distortion of the developmental paradigm of the Bildung is reflected in the protagonist's inability to socialize. They achieve alienation instead of socialization, where the latter is the "norm" in the metropolitan Bildungsroman. Such radical refashioning of the Bildung allows the (women) authors, discussed in this chapter, to complicate postcolonial notions of progressivism and democratic belonging.

As politically conscious women writers, Johnston and Devi reconfigure the conflict between the individual and society, to mirror ideological contestations over nation making. In Mother of 1084 , the young Naxalite ${ }^{2}$ Brati identifies both the state and his patriarchal father as sources of corruption and gendered oppression. His untimely death, at the very beginning of the narrative, leaves his mother Sujata to work out why and how he developed Naxalite sympathies. In doing so the ageing, apolitical Sujata is forced to become the agent of change in his place. The state-inflicted death of the younger generation, represented by Brati, transfers the onus of "development" to the older generation, represented by his mother Sujata. This unnatural role reversal marks regression rather than progress, reflecting the failures of the postcolonial state. Sujata's journey, to discover the true implications of the political violence that claimed her son, is also a process of radicalization; since it requires the unlearning of preconceived bourgeois

\footnotetext{
${ }^{2}$ The term "Naxalite" or the Bengali word Nokshal refers to those who were recruits of the Naxalite Movement (1968 - 1975). Brati represents a common pool of Naxalite cadres consisting of college and university students, boys and girls, from working class as well as upper/upper middle-class families.
} 
liberal ideas of politics. Instead of postulating the integration of the dissident subject, the novel maps the ideological "education" of the apolitical subject. She can then become both an agent of transformatory politics, and the object of its critique.

If Devi's Mother of 1084 posits the Bildung in terms of regression rather than progress, Jennifer Johnston recasts it in terms of a metaphorical futureless-ness in Shadows on Our Skin (1977). An informed but creative engagement with the implications of insurgent politics, Devi with Naxalism and Johnston with the Troubles in Northern Ireland, forms a shared concern in both novels. Unlike Devi's Brati, however, Johnston's boy-hero Joe Logan does not get the opportunity of active political participation. He is trapped in his family life with a disillusioned, hard working mother, a crippled alcoholic father and a mundane life of poverty in a war-ravaged Derry. Joe must also give up his only hope: of forging a new family, with his friend Kathleen. Kathleen, a high school teacher with a British soldier boyfriend, leaves after being brutally assaulted by Joe's brother and his friends, who are members of the Irish Republican Army. Joe is left utterly alienated at the end of the novel, a sense reinforced by his newly acquired perception of the cost of human relationships in a context of overwhelming mistrust and violence. Because the novel is set, like Mother of 1084, in the backdrop of all-encompassing violence of the Troubles, Joe's transformation occurs unevenly; in an accelerated transition to maturity, the novel cuts his Bildung short, and leaves Joe's future in a state of indetermination.

The shared thematic exploration of the relationship of the male protagonist with women characters connects Devi's Mother of 1084 and Johnston's Shadows on Our Skin. Such a framing, I argue in this chapter, links the trajectory of the Bildung to the private sphere of the family, and emphasizes the structuring influence of the lived, domestic realm on the very idea of "coming-of-age". The Bildung of the putative male protagonist is deeply connected to the 
gendered constructions of domesticity. These narratives, however, refuse to reiterate the seamless gendering of the male hero, or the hegemonic, male nationalist projection of a sanctified, venerated and symbolic feminine figure ${ }^{3}$. Instead, both novels depict complex female characters, who highlight the material and ideological disparities of the decolonization process. The close relationship of the two male protagonists - Brati in Mother of 1084 and Joe in Shadows on Our Skin - with the women characters in these novels, determines the narrative arc. The distorted Bildung is represented in these novels through the inability of the male protagonists to identify, ideologically, with nationalisms that have failed to accommodate a feminist self-expression.

Unlike India, which is often used as a representative example of postcolonial selfdetermination ${ }^{4}$, it is striking that Northern Ireland has fallen out of critical conversations on decolonization. Northern Ireland, in fact, posits a particularly problematic case of metropoleperiphery relations. With its long and insidious battle with sectarian conflict, and vicious street violence, it is often represented as a space of "its own" kind. While the Irish colonial experience

\footnotetext{
${ }^{3}$ Postcolonial feminist scholarship from Ireland and India has highlighted the complex relationship of gender with constructions of nationhood. Geraldine Meaney, for example, draws on the Indian political philosopher Ashis Nandy's argument that the history of colonization is also concomitantly a history of the feminization of the nation. In her articulation of Irish womanhood and its problematic representation in the Constitution of the independent nation, Meaney illustrates how the formation of the Irish nation-state is predicated on the relegation of women's rights and issues. For a more detailed study see Meaney's Sex and Nation: Women in Irish Culture and Politics. Dublin: Attic Press, 1991. Similarly in the Indian context, postcolonial feminist scholarship has drawn attention to the implicit co-opting of women's struggles and participation in nation-building by the dominant strands of (male) nationalism (Sinha 2006; Sarkar 2001).

${ }^{4}$ See Arif Dirlik's extensive discussion of academic postcolonial theory's fetish of India as an exemplary case of postcolonial nation-formation in "The Postcolonial Aura: Third World Criticism in the Age of Global Capitalism" Critical Inquiry 20.2 (1994): 328 - 356.
} 
draws parallels with those of other geo-political spaces such as India ${ }^{5}$, Northern Ireland remains a quarantine of a unique context-specific violence. Most studies on Northern Ireland adopt a sociological approach, seeking to uncover patterns of political dissent, and state experiments in their repression. These either ignore, or deliberately sidestep, the issue of British colonial involvement in the region. Precisely for this reason, as I show in this chapter, Northern Ireland must be viewed in relation to the Republic of Ireland, as a periphery within the periphery. Locating the Northern Irish situation in a comparative frame with India dismantles (dominant metropolitan) projections of its violence as arbitrary or inexplicable ${ }^{6}$. Instead, the Northern Irish Troubles must be situated in relation to, and in conversation with, comparable oppression of marginalized populations in the peripheries of the world-system.

Set in the war-like backdrop of the Naxalite uprising ${ }^{7}$ in India, and the Northern Irish Troubles $^{8}$ in Northern Ireland, respectively, Devi's Mother of 1084 and Johnston's Shadows are both novels from the 1970s and of the 1970s. This is a peculiar historical moment, writes

\footnotetext{
${ }^{5}$ See for example Michael Silvestri's Ireland and India: Nationalism, Empire and Memory (Palgrave Macmillan, 2009), Eoin Flannery's Ireland and Postcolonial Studies: Theory, Discourse, Utopia (Palgrave Macmillan, 2009) and Tadhg Foley and Maureen O'Connor Eds. Ireland and India: Colonies, Culture and Empire (Irish Academic Press, 2006).

${ }^{6}$ Shaun Richards puts forth a particularly compelling case for the reductive and even reactionary nature of a tragic theater that seeks to project Northern Ireland in fatalistic terms. For a detailed explication see his essay "In the Border Country: Greek Tragedy and Contemporary Irish drama" in C.C. Barfoot Ed. Ritual Remembering: History, Myth and Politics in Anglo-Irish Drama (Rodopi, 1995).

${ }^{7}$ A peasant uprising in the Naxalbari district of North Bengal, from which it derived its name, triggered the Naxalite Movement. It evolved into an urban movement incorporating vast numbers of industrial workers, lumpen classes and students. It was active in several states across India from the late sixties to the mid-seventies when it was crushed brutally by the Indian government.

${ }^{8}$ Northern Ireland (as distinct from the Republic of Ireland) has experienced continuing political instability since the partition of Ireland in 1920. The political strife is between the predominantly Catholic Republicans and nationalists and the predominantly Protestant Unionists. While Republicans and nationalists have agitated for complete independence from the United Kingdom, the Unionists have sought a political coalition or unity with Britain and the Commonwealth.
} 
Frederic Jameson in his essay, "Periodizing the Sixties", marked by a worldwide stand against imperialism ${ }^{9}$ (182). It was heralded by world-historical events, such as the student protests in France, the Civil Rights Movement in the United States, and the Cultural Revolution in China. These movements for self-determination, led by peripheral and subordinated groups across the globe at the same historical moment, informs Devi and Johnston's formulations ${ }^{10}$ of the Bildung. Writing in the critical "watershed" period of the 1970s, the authors are able to both adapt, and reconfigure, the revolutionary impetus of the previous decades into the Bildung form. The novels chart a radical ideological "education" that mimics the larger symbolic "self-formation" of oppressed groups globally. It becomes almost mandatory therefore, to situate Johnston and Devi's novels within this global moment of self-formation, "in which 'liberation' and domination [were] inextricably combined" (Jameson 207, my emphasis).

The trope of "youth", a common feature in both Mother of 1084 and Shadows on Our Skin, captures the tumultuous and rebellious impetus of the 1970s. In Shadows, Joe the protagonist is presumably in his early teens. Although the novel does not explicitly state his age, his "youth" is configured in symbolic terms to comment on the uncertainty and futureless-ness of contemporary Northern Irish society. In Mother of 1084, similarly, Brati represents the Bengal youth who harbor Naxalite sympathies. Such revolutionary youth, the novel suggests, are

\footnotetext{
${ }^{9}$ The struggles of national liberation in the so-called Third World mark, according to Jameson, a global restructuring of power. One of the contradictions of the process is that the category of "social class" as a universal and abstract concept suffers a crisis of institutional implementation in the 1960s and 1970s, leading to the emergence of non-class categories such as race, gender, nationality etc. For a fuller explication of Frederick Jameson's influential view, see his essay "Periodizing the Sixties".

${ }^{10}$ See Simon Prince's insightful essay, "The Global Revolt of 1968 and Northern Ireland." (2006). Prince illustrates the influence of the global 1960s in shaping the course of the Northern Irish Troubles. Prince argues that despite its intensely sectarian character, the Troubles shared at least an ideological affinity with the struggles for self-determination and political independence, particularly, the ongoing struggles of the Third World.
} 
delegitimized by the postcolonial state. Because his youthful rebelliousness challenges the hegemony of the postcolonial nation-state and nationalism, the latter must cut short, through violent murder, the course of Brati's self-formation. However, Sujata, the mother of the deceased Brati, takes up the question of self-formation (unlike Shadows) for herself. The Bildungsroman form itself is nuanced to reflect the unique socio-political situation of the Indian periphery.

The trope of youth has figured insistently in the modern Bildungsroman, from Dickens, Jane Austen, to Tagore and Joyce. According to Franco Moretti's influential account of the European Bildung, "youth" as literary trope is inextricably linked to the incursion of an industrial, capitalist modernity. It is "the new and destabilizing forces of capitalism," writes Moretti, that "impose a hitherto unknown mobility ... and interiority" upon youth, marking the latter as a powerful "material sign," and motor of modernity (555-556). In the case of "peripheral modernity" (see Parry 2009), the trope of youth conveys a differently accented, non-metropolitan social imaginary. Here, more frequently, the ephemerality of youth is emphasized, and correspondingly, its capacity for change undermined. These youthful protagonists do not achieve socialization, because they are caught in a maelstrom of misplaced violence, in which the dynamic evolution of youth is frozen or thwarted.

Because the advent of modernity is inevitably an uneven process in the periphery, the reconfiguration of metropolitan literary forms, such as the Bildungsroman, is always problematic and keenly contested. Charting the contradictions in the importation of the novel form to $19^{\text {th }}$ century Brazil, the noted Marxist critic Roberto Schwarz, for example, underlines, the "misfit between ideology and reality". This "misfit" occurs primarily in spaces of the peripheral nations, according to Schwarz, where the ideals of human freedom and social equality are never fully and 
adequately achieved because of their particular, uneven form of social development ${ }^{11}$. The writer at the periphery of capitalism, Schwarz argues, would have to "repeat this dislocation on a formal level if he was to keep up with the objective complexity of his material ..." (41). Otherwise, these discrepancies of social reality are mirrored in the literature of the periphery, in "an involuntary and undesired way, surreptitiously and as a defect" (42). Only when the linear, developmental paradigm of the Bildungsroman is subverted to reflect the protagonist's "alienation", as is the case with both Shadows and Mother of 1084, does it reflect the objective reality of their locations.

Like the classic Bildungsroman, the individual's "education" in Shadows and Mother of 1084 takes place in relation to the family. In Devi's novel, Brati articulates the family as an institution of oppression, presided over by the patriarch Dibyanath, who embodies the corruption of the state. After his murder at the hands of the state, Brati's mother, Sujata, recalls her son's grim reminder that she belongs to a class that Naxalites consider, their "enemies" (16). Her family never sympathizes with her, as they never did with Brati, since both rebel against the family's self-centered values. In the Logan family, depicted in the novel Shadows, ideological differences are subsumed under overwhelming economic deprivation. Yet, when they do surface, they reveal the dangers of a misplaced (masculinist) idealism represented by the likes of the

\footnotetext{
${ }^{11}$ See also Joseph Slaughter's important essay, "Enabling Fictions and Novel Subjects: The "Bildungsroman" and International Human Rights Law." PMLA 121.5 (2006):1405 - 1423. Drawing a theoretical correlation between the crises of decolonization movements in the preCold war era Slaughter interrogates the interconnections of the novel genre and human rights legal discourse. Slaughter's suggestion that human rights law and the Bildungsroman may be "mutually enabling fictions" serves to nuance the many paradoxes that inform the positioning of the bourgeois, white, male as the normative marker of human development (1407). The "Third World" Bildungsroman in particular, problematizes such subject-formation emphasizing the "exclusions and disparities" of canonizing the Bildungsroman as an articulation of universal human development (1418).
} 
father figure, Mr. Logan. The only character keeping the family afloat is Mrs. Logan, who, like Sujata, is disillusioned with her husband.

In both of the novels, the family is depicted as a particularly crucial social space, where the implications of youth and education may be grounded, and more crucially, contested. The non-conforming male heir: the son who fails to become the normative citizen-subject because of his revolutionary impulses: invariably challenge the confines of such domesticity. In both narratives, larger ideological questions of nation formation impinge upon the structure of the family, altering the modes of identification that validate the social role of the protagonists.

The family that is unable to accommodate its youth inevitably reflects the crisis of the nation, caught in the crosscurrents of drastic social change. This multifaceted interaction between family and nation collapses the division between the "private" and the "public," and reveals the fractures in the very idea of nation building. Due to the delegitimized role of the male youth, it is the mother, in both narratives, who must come to embody the contradictions of late-modern development. In Mother of 1084, Sujata reinvents herself to become the protagonist who can carry his revolutionary ideology, in his place. On the other hand, Mrs. Logan remains the unclaimed heroine, whose struggle highlights the failures of masculinist nationalism, as embodied by her husband as well as the colonial state. The mothers in both texts emphasize that in the unevenly developed periphery, gendered constructions of public and private are fiercely contested.

In both novels, the mother and son relationship foregrounds the tension of political reaction in the domestic realm: Declan Kiberd has written that Irish literature often posits an "over-intense, clutching relationship between mother and son," precisely because the husband 
has failed in their social role. The mother, in such cases, "sought from their sons an emotional fulfillment denied them by their men.” (381) The centrality of the mother-son relationship in both Johnston's and Devi's novels, suggests a disillusionment with, and distrust of the father figure. One inevitable result is that it creates powerful women characters, who serve as "surrogate fathers" (381). Kiberd's definition of motherhood aptly summarizes not just Mrs. Logan's situation, but Sujata's as well. It perhaps explains why Dibyanath is projected as an allout villain with no redeeming qualities whatsoever. It is only by an exaggerated vilification of his patriarchal values that Sujata, like Kiberd's Irish mother figure, can claim her own identity as an oppositional subject.

The overlapping gender formations in spaces that are otherwise so culturally and historically disparate suggest that, for both Johnston and Devi, nation building is a fundamentally contradictory process. It is founded not only upon the ideological oppression of politically dissident subjects, but gendered (and classed) oppression. The trajectories of the two women, Sujata and Mrs. Logan, are vastly different. Yet they represent characters whose alienation from society, family and state is complete. If the revolutionary sons pose a conundrum for the state in Shadows and Mother of 1084, so do the women who have lost faith in the system.

As peripheral spaces that experienced turbulent youth movements around the same time, Northern Ireland and India offer critical case studies that exemplify the structuring influence of revolutionary history on literary form. Northern Ireland and India constitute distinct modes of peripherality. The geographical location of Northern Ireland has ensured the long, insidious, imperialist involvement of Britain in its political and economic order. India in turn, has struggled with internal problems of bureaucratic corruption, economic and social unevenness, and religiously motivated violence. The persistent problem, in both contexts, has been the failure of 
the state to provide adequate constitutional safeguards to its disenfranchised citizens, including a substantial urban and rural proletariat, religious minorities and women.

The Nehruvian-era (1947-1964) reforms in India provide an example of the postcolonial government's failure to deliver on the promises made during the anti-colonial struggle. One of the reasons the Naxalite movement gained such force in India was because of the Nehru government's systemic co-opting of socialist ideals of welfare, in favor of a more aggressive, Western-capitalist model of development (Brass 275). In Northern Ireland, the British government's callous handling of the volatile political climate, which was largely their own creation, gave rise to a vicious cycle of social anomalies. The "standards of British democracy" seem incongruous in the context of Northern Irish Troubles (1968-1998), where the newly reinstated Stormont Parliament routinely overlooked the systemic discrimination and oppression of the working-class Catholic minority (Dixon 94).

Both Johnston's and Devi's writings speak to these rampant incongruities in the very idea of liberal democracy in the periphery. Radical or insurgent politics is not merely incidental to their writing, but a determining influence on their formal and aesthetic choices as writers. In an interview given in 1983, Mahasweta Devi categorically points out that, "a story writer should be motivated by a sense of history that would help her readers to understand their own times" (Quoted in Tiwari). Speaking of her interest in the Naxalite movement, specifically, Devi further notes that it was the first major event she "felt compelled to document" (Tariq 2). The author's specific word choice of "documentation," as a form of fiction writing, highlights the importance of a truthful representation of a peripheral reality. The author's commitment to a realistic representation of history can, and does motivate the reader, to perceive the social injustices in which they are deeply implicated. 
Johnston, whose literary and political vision is distinct from Devi's, emphasizes the multidimensional character of the Northern Irish situation, which complicates a simple "leftright" politics. For Johnston, the "war zone" of troubled history inevitably shapes the iconography of author and reader alike: "The border is a state of mind and little by little the state of mind must change" (quoted in Moloney 68). This history is invariably part of a larger psychosomatic process of development, according to Johnston, that must be charted truthfully. In this regard, Johnston shares Devi's commitment to social reality - "I am not saying who is right and who is wrong in the Irish situation as much as I am trying to write about the complex overlapping of history and personalities involved in being Irish in the past and at the moment" (Moloney 68). In Shadows, as in Johnston's other works, this critical overlapping of social reality and subjective experience influences the particular modalities of the Bildung.

The confluence of history and narrative form, that Devi and Johnston seem to indicate, is actualized in the Bildungsroman form of their novels. Tobias Boes, Jed Esty, Todd Kontje and others have contended that the Bildung emerges out of an intellectual and philosophical striving, in eighteenth century Europe, towards "the emplotment of History"12 (Boes 275). It is at this crucial juncture that the Bildung undergoes a radical shift from its original didactic purpose, of "God's active transformation of the passive Christian," to a more secular, egalitarian model of "self-formation," achieved through the protagonist's own conscious effort. The power of this transformation is conceived both in terms of a symbolic "education," and linked to the ethos of self-discipline. Visible in its earliest form in Goethe's Wilhelm Meisters Lehrjahre $(1795)^{13}$ - the

\footnotetext{
${ }^{12}$ For a detailed discussion of the "emplotment of history" in Goethe's Wilhelm Meister's Apprenticeship (1795), see Boes' (2008) essay, "Apprenticeship of the Novel: The Bildungsroman and the Invention of History, 1770 - 1820".

${ }^{13}$ Goethe's Wilhelm Meister's Apprenticeship (1795) is considered to be the first literary example of the Bildungsroman. For further critical readings of the text see Todd Kontje's
} 
work considered by many as most representative of this shift - the Bildung assumes novel form by incorporating elements of "romance" and "adventure," before evolving into the contemporary Bildungsroman.

All of these classic components of the Bildung are woven into the plot structure in Shadows and Mother of 1084. Because they emerge from the periphery, the egalitarian model of self-formation is modified to incorporate the meta-narrative of a collective consciousness. As Marc Redfield observes, "the temporal arc of the individual subject's Bildung always at least potentially exemplifies that of humanity" (171). The protagonists who achieve this radical consciousness, derive their awareness from the society in crisis, and also represent its conscience. The trope of "education" links their development from a state of relative innocence, to a heightened awareness of the disjuncture in their social and familial roles. It is only when they confront the ideological battles of their context, that their social role assumes a certain literary significance. The major shift here from the principles of the traditional Bildung is in the convergence, of external forces and interior self-cultivation, in forming a Bildung type developmental pattern.

Mother of 1084 and Shadows offer instances where Johnston and Devi deviate from their usual social settings. In Johnston's other novels, the characters usually hail from middle and upper-middle class backgrounds. In Shadows she focuses instead on a working-class family, to illustrate a state of extreme disenfranchisement. This is in keeping with a point that Joe Cleary makes that, in Northern Irish cultural representation, the Catholic working class rather than middle-class family forms a suitable backdrop for the enactment of a domestic tragedy (234).

seminal book Private Lives in the Public Sphere: The German Bildungsroman as Metafiction (Pennsylvania State University Press, 1992). 
Devi, on the other hand, is known for her representation of tribal communities, the urban subproletariat, and female laborers who form the lowest strata of the Indian population. In Mother of 1084, Devi deliberately moves from an underclass to a markedly middle-class milieu. Such a move allows the author to question ideas of democracy, equality and progress within a middleclass context where they are more easily taken for granted.

The multimodal engagement of individuals with an oppressive state and society is a recurring theme in Johnston and Devi's literary works. They represent a tradition that is largely, even today, ignored in mainstream literature - the nonconformist, dissident woman writer. Devi's Agnigarbha or "Womb of Fire" (1978) is a collection of short political narratives focused primarily on underclass women characters, while her Aranyer Adhikar or "The Rights of the Forest" (1979) charts the history of the Munda insurrection ${ }^{14}$ in colonial India. Also worth mentioning in this regard is the novel Chotti Munda and His Arrow (1980), in which Devi uncovers the miseries of bonded labor and the struggle of the tribal communities, disavowed as citizens on the state, who organize and fight against its malpractices. Johnston, too, combines both political commentary and historical narrative in novels such as How Many Miles to Babylon (1974), which is set during the First World War, and The Old Jest (1979) that traces the role of the IRA in the Irish War of Independence. In The Railway Station Man (1985), she combines romantic love and politics, with the protagonist's son joining forces with a shady group of Dublin based guerillas.

A sustained ideological engagement with the volatile and controversial topic of political violence connects Johnston's Shadows on Our Skin and Devi's Mother of 1084. The latter

\footnotetext{
14 The Munda Insurrection (1831-32) was the first large-scale tribal rebellion in colonial India against the British Raj.
} 
articulates an implicit identification with the Naxalite cause, as expressed through Sujata's embracing of her son Brati's revolutionary ideals. Johnston's Shadows emphasizes the ideological ambivalence of the Troubles through the women characters, such as Mrs. Logan and Kathleen, who elucidate its many internal contradictions and damaging impact. The two novels however present overlapping formulations of revolution, as an ideology that has complex ramifications for the family. Revolution is entrenched as much in the everyday lived experience of domesticity, as it is manifested in the ebb and flow of national and global history. The value of framing these contesting and contrasting examples together is that, collectively, they highlight the myriad types of self-formation that could emerge at the periphery. As I discuss, it is only by reading Devi's Shadows and Johnston's Mother of 1084 comparatively, that their ideological underpinning as literary-political fiction become visible.

\section{The Bildung and the Northern Irish conflict in Jennifer Johnston's Shadows on Our}

\section{Skin}

Shadows on Our Skin, one of Johnston's very first Trouble novels, revolves around Joe Logan, an adolescent boy living in Derry, Northern Ireland. Spanning only a few weeks of the protagonist's life, the narrative explores the effects of political violence on human relationships. Joe feels entrapped by his family, especially his father who was once a part of the national liberation struggle, and his brother who is involved with the IRA. Joe's mother, a working-class woman who supports her family, is similarly trapped within the household, embroiled in domestic chores. The family lives under the constant fear of police raids - a common phenomenon in the Catholic tenements of Derry. The plight of the family, "marked" as subversive and violent, is particularly suggestive. It elucidates how the ideals of democracy are 
often sidestepped for disenfranchised communities; for them, the divide between public and private, an integral aspect of metropolitan democratic culture, is no longer applicable.

As a young boy growing up in this working-class Catholic family in Derry, Joe must learn to recognize the objective reality of his existence. Joe's "education" charts this journey from naïve idealism to disappointment and alienation, a trajectory that arguably mirrors the painful history of Ireland's North. As the youngest member of the family, Joe is often riddled with the palpable tension between his parents and his elder brother. Even though he maintains a studied detachment from (what he perceives as) the petty squabbles of family life, he writes poetry to vent his frustrations and hone his creative skills. Like the classic Bildungsroman boyheroes before him (David Copperfield, Huckleberry Finn, Tom Sawyer or even the adolescent Stephen Dedalus), Joe the boy-hero, must navigate an inherently incongruous social world before he acquires maturity.

The emergence of the boy-hero as a literary figure resonated powerfully with the rise of an Irish literary tradition. Following a resurgence of interest in Cuchulainn as a figure of iconic boyhood in the nineteenth century, the Irish "schoolboy novel" gained recognition as a nationalist genre, closely aligned with the Bildungsroman mode (O’Neill 149). The difference between the English and Irish schoolboy novel rests, according to O'Neill, on formulations of the Bildung. Whereas the English school boy gains upward social mobility through his "adherence to social convention," such adherence to norm, for his Irish counterpart, inevitably results in "frustrated ambition and internal struggle" (150). In the politically unstable context of Northern Ireland, the Bildung can only be successful through a radical reconfiguration of its norms. Joe's transformation into an alienated individual undermines the idea of a "heroic" youth; similarly, it releases the male hero from the overdetermined text of cultural nationalism. 
Joe's family, consisting of his father, mother and elder brother, defines the entirety of his existence. Their predominance in his life leaves very little room for his poetic imagination to flow freely. His mother depends on him for minor domestic chores; his father for his supply of cigarettes and alcohol; and his brother helps to sabotage his only source of freedom - his friendship with Kathleen. Despite the fact that his mother does support him financially and other wise, Joe's family is presented as an impediment to his imagination, and certainly to his growth as a human being. The corrugated iron boundary walls all over Derry reflect his circumscribed existence, barring his imagination from going beyond them. However Joe's life like that of so many around him is threatened by the danger of a very real and conspicuous violence.

Johnston builds an atmosphere of grim foreboding from the very beginning of the novel. A lengthy passage, describing Joe's walk back from school, aptly captures the atmosphere of uncertainty that the boy-hero has to navigate: “There weren't many people about. Down below him in the distance a couple of shots were fired, and then there was silence ... he passed a couple of shops, the windows barricaded, with stripes of light between the planks, "business as usual" scrawled on the closed doors ... this stretch of the road always put fear in him" (4). The poignant image of the barricaded shop window, with its ironic claim to "usual" business, captures the unusual climate of the Troubles. The mundane rituals of everyday life have been modified to cope with the danger of an overwhelming violence.

If the novel establishes IRA violence as an everyday reality in the Northern Irish context, it also exposes the omnipotent, psychosomatic violence of the state. The myriad paraphernalia of state control - ambulances, fire engines, helicopters reconnoitering the city, the sudden sound of gunshots and bombs exploding in the streets - all reinforce the palpable danger of living in the shadow of potential death or injury. The overwhelming presence of a war-like crisis transforms 
Joe and his brother Brendan's shared bedroom into a metaphorical battlefield: "The smell of burning crept even through the closed window ... the house trembled as a helicopter rattled over the roof, the searchlight probing, searching. He wondered if they had X-Ray gadgets that could see through the brick walls and curtains ... even into the blackness of people's skulls" (25). This is a powerful image of the surveillance apparatus at work. In disembodied form, it assumes almost supernatural powers in Joe's boyish imagination. The intrusion of violence into the innermost sanctum of the domestic suggests how deeply entwined Joe's and Brendan's lives are with the crisis in their context.

Even though the violence described in Shadows is fictional, it certainty resonates with topical events such as the Bloody Sunday ${ }^{15}$ in 1972, and the subsequent fall of the Stormont Parliament. These events, having occurred only a few years before the novel's publication in 1977, would be fresh in public memory, and certainly familiar to Johnston. The incidents of political violence that Shadows recounts, thus, have a specific purpose: historical documentation. David McKittrick and David McVea argue that the violence of Bloody Sunday, witnessed by the ordinary people in Derry or Londonderry, actually turned them decisively against the British who had fired upon civil rights marchers. Concomitantly, public sympathy for the Provisional and Official IRA grew manifold, with many youths becoming recruits (79). The way the characters, especially the male characters in the novel, respond to this violence must be understood in the light of these historical factors.

\footnotetext{
${ }^{15}$ The Bloody Sunday is a term used to describe the events that occurred on January $30^{\text {th }} 1972$ in Derry, Northern Ireland. Fourteen people died on that day when the soldiers of the British Parachute Regiment stationed in Derry opened fire on a large group of supposedly "illegal" civil rights marchers. The event created shockwaves in the British Parliament; later, the Labour Prime Minister Tony Blair promised a thorough inquiry into it.
} 
Joe's father, Mr. Logan, is one of the first characters introduced in the novel. The contradiction of his character is established at the very beginning: Mr. Logan is revealed to be a Civil $\mathrm{War}^{16}$ veteran who is now physically crippled, unemployed, and an alcoholic. A lengthy description of the old man, as viewed by his son, reinforces this sense of physical decay: "The eyes opened to cunning slits, gauging, biding, then a little more they parted to show misty pupils surrounded by a web of red streaks. Mucus pulled at the corners" (7). This provocative image suggests both manipulation and dependence - the twin attributes of the character of Mr. Logan. But it is also a chronotope, suggesting the passage of time and changing values from one generation to the next. Mr. Logan in fact cuts a rather familiar figure - one who has "survived" as a literary prototype in Irish fiction.

Declan Kiberd writes eloquently about the particular predicament of the Irish figura paterna: "The Irish father was often a defeated man, whose wife frequently won the bread and usurped his domestic power, while the priest usurped his spiritual authority" (380). As a result Irish literature is replete, writes Kiberd, with father figures "lamenting the red-blooded heroes now gone and evoking the conquests achieved in their own pasts" (380). Mr. Logan is, perhaps, a classic example of this prototype. His motivations throughout the novel remain self-centered, even though he is almost entirely dependent on his wife for economic support. He sends out his son for beer and cigarettes while there is a street shooting, confident that, "They're not going to be wasting their bullets on you ..." (7). His naïve belief that his past as "Civil War hero" would ensure his son's safety is not only dangerous, but based on a fundamental misunderstanding of the scope of state-violence in the present. Mr. Logan represents, one can argue, the déclassé

\footnotetext{
${ }^{16}$ The Irish Civil War (1922-23) followed the Irish War of Independence. It involved the Irish Republicans and the British-backed Irish nationalists. For a critical study on the fate of Irish Civil War veterans such as Mr. Logan, see Ann Dolan's Commemorating the Irish Civil War: History and Memory, 1923 - 2000 (New York: Cambridge University Press, 2003).
} 
individual, whose nationalist vision has become irrelevant in a moment of enormous social violence.

Joe's mother Mrs. Logan is the sole bread earner of the family ${ }^{17}$. Rather than "usurping" power from her husband, as Kiberd suggests, she has been forced to assume control because of his failure to do so. Working menial jobs at a local café, Mrs. Logan attempts to keep the family running. In fact, Mrs. Logan concretely represents the many working-class women in Northern Ireland, who had to take responsibility for an entire household because their husbands have been betrayed by the ruling government. Like her husband, she, too, represents a familiar demographic in Northern Irish fiction - that of the 'working-class mother trapped in a climate of Movement murders' (Weekes 89). Understandably, because of her difficult life, Mrs. Logan is apolitical, ideologically detached, and a profoundly disillusioned individual who does not share her husband's enthusiasm for revolution. In fact she disparages his glorious vision of revolutionary masculinity: she caustically remarks, "the only thing you ever rebelled against was work" (10). The ideological differences between Mrs. Logan and her husband constitute an unspoken tension within the family that resurfaces at multiple critical points in the narrative.

Mrs. Logan's views reinforce the unevenness of life at the periphery. It is a context where glaring structural asymmetries have destroyed the revolutionary potential for change. The ideals of social reform and anti-imperialist struggle, which form a crucial aspect of Irish history, have been de-legitimized in their own home as it were. Mrs. Logan's situation may be that of a

\footnotetext{
${ }^{17}$ The situation of Mr. and Mrs. Logan is strikingly similar to that of "Captain" Jack and Juno in Sean O'Casey's highly regarded play Juno and the Paycock (First staged in 1924). Set in the working class tenements of the Dublin of 1920's the play posits the same gender roles between husband and wife as Johnston's Shadows. Captain Jack, so called because of his dramatic and exaggerated tales of his own heroism makes excuses of physical infirmity in order to not have to work. Juno, like Mrs. Logan supports him financially. O'Casey's play may have been a possible source of inspiration for Johnston in her conceptualization of the Logan family dynamics.
} 
financially independent woman, but she is also a peripheral subject; for this reason, her independence does not translate into actual empowerment. Both Mr. and Mrs. Logan belong to the lowest strata of the society, where any ideology or politics has been effectively rendered useless. Mrs. Logan's apolitical views and her refusal to support her husband and son, ironically, make her the most politically astute character in the family. She knows that (in this context) the value and mode of social participation rests on the individual's class position more than their ideological beliefs.

As a woman who had had to bear the brunt of both forms of ideology - the state ideology of coercion and the republican ideology of counter-violence - Mrs. Logan embodies the contradictions of the Northern Irish situation. She is a citizen-subject only in name, but represents a demographic whose miseries are never accounted for. She cleans up after police raids, and goes to work the next day to put food on the table; she faces police interrogation about the actions of her son, Brendan, activities she may not even be aware of. Her social role as worker, wife and mother demonstrates a situation of abject marginalization and exploitation. Mrs. Logan illustrates the inevitably gendered nature of nationalism and colonialism. This is strikingly expressed in Mr. Logan's enthusiastic endorsement of Brendan as his revolutionary son, while Mrs. Logan's sacrifices on their behalf remain unacknowledged.

One of the issues that Mr. and Mrs. Logan routinely argue about is Brendan, their elder son, and Joe's brother. Brendan enters the narrative as an outsider, coming in from England; he is able to view both the Logan household and the situation in Derry from a somewhat detached perspective. He is as invested as his father in the idea of nationalist-revolutionary heroism, as well as acutely aware of his own disenfranchised social standing. Brendan's arrival elicits mixed reactions from Mrs. Logan, who is apprehensive of his association with the IRA. For his father, 
however, Brendan is the embodiment of genealogical continuity: of his own nationalist, military ethos. Brendan's physical presence buttresses Mr. Logan's sense of self-worth, while his English money sponsors their frequent visits to the pub. The affinity between father and son compounds Mrs. Logan's fears that her son may be headed for the same failed future as her husband.

Mr. Logan's relationship to Brendan appears to be an exemplary one. Not only has Brendan picked up the mantle of his father's ideology, he has also adopted his legacy of a zealous masculinity. Because such a relationship is embedded in the contradictions of the colonial contact-zone, it is downright dangerous to the Logan family. Describing constructs of masculinity in the Northern Irish novel, Caroline Magennis writes that, "if one of the perceived roles of fathers in relation to their sons is the replication of normative codes of masculinity and the development of the masculine self, then this may well prove problematic in Republican families, as fathers press upon their sons narratives of oppression and victimhood" (108). While such a legacy has dangerous repercussions in an escalating cycle of violence, obviously, one also needs to be attentive to the conditions of extreme unevenness that created this problem. If the result of the father-son bond is violence, its root cause is a shared experience of disenfranchisement at the hands of the colonial state.

Soon after Brendan's arrival there is an incident of a nighttime raid by the British soldiers. This incident directly establishes the palpable threat under which the Catholic community is forced to live. Joe and Brendan lie in bed listening, while the army "lifts" one of the neighbors, Sean Buckley: "Suddenly there was a single shot. With a crack it hit a wall somewhere and then whined off down the street. Joe ducked back into his pillow ... for a moment the child stopped crying and then began to bawl. The soldiers ran for cover. Their boots must have been sending up sparks in all directions, Joe thought. He'd seen that happen before". 
From the sounds in the street, Joe and Brendan realize that the shot is in fact a retaliatory one; fired upon the army, who promptly resort to a common tactic of protection - using poor Catholic children as cover, saying, "Anything comes our way comes their way too" (59).

The incident demonstrates, with a sense of deep foreboding, that even children are transformed into instruments of war. It shows the capriciousness and cowardice of army personnel, who do not hesitate to use children as cover to save their own skin from possible attacks. The reaction to the army in the working class Catholic tenements is one of extreme hatred and suspicion. As representatives of the state, the army and the police are direct agents of repression, responsible for the monitoring and control of dissident subjects. Joe and Brendan's attempt try to avoid being hit by stray bullets highlights the fact that they are living in a "warzone". This is a space where ordinary people's homes have turned into army bunkers. The army personnel drag out women and children, even the elderly from their homes, lining them up against the walls for interrogation as Brendan and Joe listen with bated breath. It is reported the following day that the army had "lifted" five different people the very same night.

By uncovering the everyday repercussions of violence, Johnston offers an alternative representation of the Northern Irish situation to that of the popular media. According to Christine St. Peter, media representations, particularly in the "West," "support a state-authorized monologue in which the violence of a particular group, the IRA, can be constructed as uniquely lawless and barbarous, a narrative that legitimizes the violence of the state and the dominant order.” (95) The episode described in the narrative is particularly significant, therefore; it documents and uncovers a less acknowledged side of the Northern Irish situation - the violence imposed by the state towards local communities. The incident clearly exposes a form of state violence that is directed at, instead of being protective of, civilian families. Such events reinforce 
the idea that the state can assert its dominance only through the physical destruction of targeted domestic structures.

It is in this atmosphere of all-encompassing violence, that Mrs. Logan and Brendan argue over their respective positions on the events they witness. Mrs. Logan, who is already disenchanted with the nationalist sympathies of her husband and elder son, takes a characteristically moralistic stand, saying, "If you go around creating destruction, you ask for what you get". This draws a suitably agitated response from Brendan, who "leaned across the table and drummed with a fist", saying, "There'll be no decent life for anyone here until we get the British out". When Mrs. Logan calmly tells him that there were many in Northern Ireland who did not share his views, Brendan is quick to respond that, ““... they're traitors. To Ireland and to their class and' ... he leaned even closer to her.... 'to their religion'” (65). Brendan's response sums up the ideological complexity of the situation; it is a deadly mix of a historically valid nationalism, combined with a contextual sectarianism. Mrs. Logan's response (without intending to be so, perhaps) can well be read as a message to the British, as to the IRA for whom it is directed.

If Brendan and his father exemplify the disempowerment of the male colonial subject, Mrs. Logan's condition is representative of the historic subjugation of Irish women. Describing women's relation to male nationalism, Geraldine Meaney argues that, "women in these conditions become guarantors of their men's status, bearers of national honour and the scapegoats of national identity. They are not merely transformed into symbols of the nation, they become the territory over which power is exercised" (7). Mrs. Logan's disagreement with Brendan, regarding the social implications of political violence, gains relevance once it is understood in the context of this historical conflict between conservative nationalism in Ireland, 
and the question of women's basic civil rights such as divorce and abortion. Even though the dominant problem that Mrs. Logan faces is that of an overall structural underdevelopment, her resistance is doubly entrenched in this conflict.

Meanwhile, caught in this crossfire of political views, Joe seeks freedom outside the family: in the figure of Kathleen. Joe's meeting with Kathleen is one of the major developments in the novel. Kathleen enters the narrative (and Joe's life) by symbolically appropriating his space: Joe finds one day that, "There was a girl sitting on the low wall, which he regarded more or less as his private property" (17). There is a double appropriation here - in occupying a space that Joe regarded as "private," Kathleen symbolically transgresses into his consciousness as well as his sense of life. As Joe observes Kathleen staring pensively into the landscape, he proceeds to second-guess her thoughts: “... maybe, he thought ... she was really only staring at the inside of her head. The world's longest stare. The world's most unrewarding stare" (17). There is an implicitly drawn parallel with his mode of interiority, always turned inwards in the absence of any external stimuli. Moreover, his assumed right to speak for her indicates that their friendship is a foredoomed chemistry of opposing ideas; since it is Kathleen who opens up his inner world, to myriad experiences of freedom and human bonding.

If Mrs. Logan illustrates the idealized mother figure of Irish nationalism, Kathleen, as the other significant female character in the novel, exemplifies a different kind of iconic Irish femininity. Unlike Mrs. Logan, who represents a condition of abject (if resistant) domestication, Kathleen exemplifies complete independence. She is always shown either walking, or sitting alone in liminal spaces, such as boundary walls and the edge of hills. She is a curiously carefree character who comes to Derry from Wicklow, temporarily, to work as a schoolteacher. For Joe, perhaps, a part of Kathleen's attraction lies in the fact that she has no family, which posits an 
obvious contrast with his entrapment within his own family. He feels acutely self-conscious telling her that his mother works at the Strand café, where "she performs menial tasks," because his father had been "wounded in the Civil war" and "has a bad leg" (51). When Kathleen walks him home and asks him to show her where he lives, Joe deliberately points in a vague direction, so as not to highlight the poverty of their house.

The novel's depiction of Kathleen as an unattached woman has echoes of the Cathleen ni Houlihan figure; the latter is similarly unburdened by familial ties. Such a correlation in turn makes Joe's association with her problematic since he hopes to escape his situation with her help. Traditionally, the Kathleen ni Houlihan or Caitlin Ní Uallacháin figure is associated with Irish cultural nationalism, the embodiment of an "ancient idealism" (Dean 71). In the novel, however, Kathleen remains a controversial figure: most strikingly, her love interest is a British soldier, a representative of the colonial force. Her friendship with Joe is unsustainable in the face of overwhelming political strife; and yet, she lures him away from home with little consideration for his mother's approval. The contradiction of Kathleen's character lies in her attempt to establish human relationships that surpass religious and ideological difference. In the context that Johnston describes, ideological and religious strife dominates every facet of life, so that there is really no place for Kathleen's vision of an uncorrupted friendship.

When Kathleen proposes a trip to Griannan castle, she unwittingly arouses a tumult of emotions in Joe's adolescent heart. Remembering that Brendan had in fact run into them on the road the previous day, Joe fervently prays that he, Brendan, would not betray him to their mother: "Tomorrow, oh, tomorrow. He said a quick prayer that Mam wouldn't be home before him, that the fire wouldn't be out, that Dad would be up in his stinking bed, that she would be in a good mood, that Brendan would keep his trap shut" (75). The trip becomes a sacred quest in 
Joe's mind, as a singular opportunity for escaping the mundane and banal. He closes his eyes in a frenzied articulation, in which idol worship and sexual longing inevitably converge: "Oh, please God, Oh, God, Oh ... Oh, Kathleen ... oh ... friend ... oh" (81). The exclamation has an undertone of immense pathos, coming from a teenage boy whose starved imagination conjures up a larger-than-life image of an "ordinary" girl. The episode has strong resonances with earlier literary texts in which a boyish imagination similarly usurps feminine being.

The immediate parallel of the episode is, of course, with James Joyce's short story "Araby" (1914), which describes a similar obsession of an adolescent protagonist with a young girl in his neighborhood. In fact, such idealization of female characters has a well-known precedence in Irish literary works. Kathleen is both eroticized, like Molly Bloom of Ulysses, and also bestowed with maternal and earthly qualities, like Anna Livia Plurabelle of Finnegan's Wake. In a society struggling with economic deprivation, backwardness and social decadence, a figure like Kathleen - neither girl nor woman, free yet vulnerable - immediately becomes an object of desire. Joe's attempt to keep his "friend" private, hide her from the prying eyes of his brother Brendan, and so on, however, is a quest doomed for failure.

Brendan, both surprised and amused at his brother's chivalry, confronts Joe about Kathleen: "Who was the bird?" (80), he sneeringly asks. Eager to avoid revealing too much, Joe tells Brendan that he hardly knew her. Ignoring Brendan's interrogation, Joe attempts to establish his claim over Kathleen by saying, "Why don't you leave it alone? She's my private life, my friend, my person" (81). The emphatic claim with triple stress on the word "my," reveals the depth and sincerity of his feelings for Kathleen. The triple emphasis, " $m y$ private life, $m y$ friend, $m y$ person" (emphasis added), in fact, demonstrates his sense of absolute ownership over her. It also suggests the extent to which Kathleen holds a sway over him, since she is not just a part of 
his life, but represents an alternate vision of it. Joe's recollection of Kathleen's ring (that suggests she is, in fact, not single), and his refusal to inform Brendan of it, however, anticipates the grim outcome of their sibling rivalry.

The picnic planned by Kathleen does not go as expected, since it rains heavily, despite Joe's prayers. But from atop the Griannan fort he discovers a new horizon of freedom: "The whole world swung beneath them. The fortress city was below them, its gray walls and climbing houses quite plain to be seen in the crook of the curling river that broadened then into the lough, beyond which the cliff of Benevenagh rose like a wall” (93). The sight overwhelms Joe, who is elated by the sense of freedom and openness: "it was as if he owned the world" (94). The openness of the landscape offers a sharp contrast to the "great curls of barbed wire and corrugated iron sheets," which circumscribe Joe's lived everyday (34). Even before Kathleen's arrival, he had dreamt of an experience like this: "Hills, rising gently into mountains. Mixing colors, moving light, shadows. Clouds that sometimes smothered the whole world. He had never been on top of a mountain and looked down at the world. That would really be something" (34). The experience elevates Kathleen, in Joe's mind, from a mere friend to someone who embodies freedom, imagination and dream fulfillment.

It becomes evident from their very first meeting that Brendan, too, is attracted to Kathleen. When the three of them, Brendan, Joe and Kathleen, sit around the fireplace in her apartment enjoying a dinner of toast, sausages and baked beans, Brendan tells her that he wishes to give her something: “... well ... like a kiss, or a song, or a promise”. Kathleen responds to his romantic overtures sportingly and light-heartedly, but remains non-committal towards them both. Later, during one of their meetings, Kathleen reveals to Joe however that she is in fact engaged to a British soldier named Fred Burgess, and also that she is planning to move out of Derry in 
order to settle down with Fred. Just as she is non-committal towards Joe and Brendan, she is similarly non-committal about her next destination - "I could live anywhere ... You've got to get along with people. That's important. That's all part of having an open mind. I love Ireland ... a sort of earth love ... rather than anything else" (121). The sentiment that Kathleen articulates is not unpatriotic: it is simply cosmopolitan, and an expression of her free sense of self. Kathleen does not share the same (narrowly restricted) sense of belonging that Brendan and Joe have.

From the beginning, Kathleen maintains a certain detachment from her surroundings. Kathleen confesses that she does not enjoy her job nor does she wish to be tied down to any one place. Although she is not exactly apolitical, she always maintains an ambivalent attitude towards the turbulent political situation in Derry. Johnston does not bestow Kathleen with any interiority, or reveal her private thoughts, despite the fact that she is prone to ruminations. Kathleen's relative disconnect from her immediate social context is juxtaposed against the entrapment of the other characters, particularly Joe and Brendan, who are socially or ideologically fettered to their surroundings. Just as this difference makes the brothers fall in love with her, it also makes it inevitable that the ensuing complications would culminate in violence.

The revelation of Kathleen's engagement affects Joe - deeply. Previously, Kathleen had been his only friend: someone he idealized and secretly adored. Now with the possibility of her moving away, Joe fantasizes about a life with her away from his claustrophobic life: "He would go and visit her. Stay. And Frederick. Fred. He might stay for ages. He could grow up there. He could learn to watch the world as he did. Fred would take off his uniform when he came home and you could forget what he was. He would be a man, like any other man. They would be careful of each other, and gentle, and laugh" (130). This is an idealist's vision of reality - one in which the personal and political may be disengaged from each other with the simple act of taking 
off of a (colonial, military) uniform. By putting his faith on a future that can never be achieved in realistic terms, Joe paves the way for his alienation. His naïveté does not permit him to see that a soldier's uniform cannot be de-politicized. Nevertheless, it is a vision of a much needed albeit problematic peace.

Joe's fantasies of a life with Kathleen and her fiancé Fred illuminates his search for a surrogate, alternate family. With the power of his uniform when it is worn, and a familial benevolence once it comes off, Fred posits an image of model masculinity: powerful yet nonthreatening. By contrast, Joe's father and elder brother posit extremely problematic models of nationalist male citizenship. What Joe does not realize is that Fred's "power," derived from British colonialism, is the reason for the comparative powerlessness of his father and brother. The vision of "peace" that Joe harbors as a child must be bought with the price of imperial benevolence; it would depend on Fred's acceptance of Joe. If Joe resists this "peace," he may be pushed towards Brendan's path of violence, death or possibly a life in prison. The irony of Joe's life is that the only other models of masculinity that he is aware of are his father and brother, and they clearly do not fulfill his longing for a family.

The narrative is propelled towards a fateful culmination after the British soldiers raid the Logan household. This is a critical point, especially for Joe who had found a gun brought into the house by Brendan. It gives Joe an opportunity to demonstrate his own "heroism". Realizing the full implications of having the gun found at their house, Joe hides it in his schoolbag as the soldiers ransack their dwelling, and disposes of it quietly into the sea the following day. Grateful to Joe for having protected his secret, and conscious of having narrowly escaped an arrest, Brendan decides to return to England, there to start his life anew with Kathleen. Things escalate out of control, however, when he tells Joe that Kathleen had lent him some money. He speaks of 
his decision to turn his life around, and that he was going to eventually marry Kathleen. This constitutes a breach of trust for Joe, who is revolted by Brendan's naïve confidence that he could “usurp" Joe's dream. In a final act of betrayal, Joe tells Brendan of Kathleen's engagement to a British soldier. Brendan, who has already revealed the details of his association with the IRA to Kathleen, must now ensure, through (domestic?) violence if necessary, that his connection to a violent politics of revolution remains a secret.

The significance of Joe's betrayal of Kathleen is two pronged. First, it effectively demonstrates that the "personal" and the "political" must eventually converge in a moment of crisis. Secondly, it shows a marked development in Joe's character, from a naïve teenager who sought to insulate himself from politics, to one who learns how to manipulate things to his advantage. This comes across in his slow but careful articulation of Kathleen's feelings towards Brendan: "She's not gone on you. She thinks you're weak. She told me so. She's going to be married to someone anyway. She loves him" (188). When an unbelieving Brendan calls him a "liar," Joe retaliates with the ultimate blow: "Fred Burgess is his name ... he's a soldier ... A British soldier. She wears a ring, you know. And she tells him everything” (190). Joe seems to be well aware, here, that in order to crush Brendan's presumptuous belief that he could marry Kathleen, a merging of the personal and political was inevitable. He emphasizes in his revelation that Kathleen's rejection of Brendan is based not just on personal dislike, but her ideological revulsion for everything he stands for.

The effect of this revelation is more acutely evident on Joe, rather than Brendan, who appears to be in shock. Joe runs away from the house, beyond the city limits, his heart bursting with guilt and remorse. He knows that he has done wrong in trying to break Brendan, and has in turn wronged Kathleen, in distorting a truth of which he knows nothing. Significantly, his 
feelings at this point transcend thoughts of personal injury to encompass a vision of total destruction: "What have I done? Deliberate destruction. I have told the truth, but only to destroy. I too am destroyed" (191). This is a critical moment of epiphany, when the protagonist arrives at a self-awareness that can only be compared to the hero's realization, in classical tragedy, of his “error". Joe's pronouncements at this juncture also reveal his development as a character: from a naïve adolescent boy, to an individual who is able to reflect on his own actions. Joe's realization, that in his elaborate attempt to break Brendan he has also destroyed himself, suggests a heightened consciousness that his existence is very much entrenched in the ideological quagmire he sought to escape.

The incident has serious repercussions for Kathleen's role in the story. If her benevolent, nurturing behavior had led both the boys to place her on a pedestal as the "virgin," news of her connection to a British soldier (the enemy) immediately makes her a "whore". In charting Kathleen's metaphorical fall from grace, Johnston seems to be deliberately deconstructing a familiar gender paradigm in Joyce's influential oeuvre - the casting of women as either virgins or whores (Henke and Unkeless 1983). The episode resonates with the story "Our Lady of the Hills," by Yeats, in which a beautiful Irish girl, idolized by young boys loses her divinity in their eyes when one of them realize that she wears a petticoat like ordinary women. The revelation of Kathleen's engagement to a British soldier, and her giving money to Brendan, similarly demystifies her in Joe's eyes. It constitutes nothing less than a betrayal of the vision of his peaceful co-existence with Fred and Kathleen.

It is noteworthy that the development of Joe's character happens within a very short time frame: beginning with his detached commentaries on his surroundings, to his final realization of becoming an agent of destruction. Because Joe's self-definition is essentially a negative one, his 
development, too, seems warped. Instead of achieving what he initially sets out to do - transcend his surroundings, rise above petty politics and become a poet - Joe entrenches himself even further in pettiness, competition and jealousy. Joe's emphatic claim about destroying himself and others around him harks back to the vivid physical destruction, which already forms an inextricable part of his social reality. Through Joe's situation, Johnston seems to suggest, that in the periphery the transition from youth to maturity occurs abruptly, rapidly and unevenly, such that the conventional generic rules of the Bildungsroman do not apply. Because he inhabits the periphery, the trajectory of his growth does not necessarily correspond with age.

Joe's accelerated growth as someone who learns to accept his social role suggests a little acknowledged aspect of the Bildungsroman - the question of consciousness in self-cultivation. Writing about the Bildungsroman of the 1970s, the critic Susan Wells writes that in charting the individual's attempt "to find a place in social life," the Bildungsroman is "responsive to the pressures of political reaction" (71). In a context of insurgency and hostility, the protagonist's attention invariably turns inwards, to "interior self-culture" (Ibid). Joe goes, very quickly, from a long-suffering boy to an idealist to an alienated and demoralized individual, and he must live with the consequences of his error. This results in an interesting plot where interior development takes the place of external action. In the absence of a lengthy time-span that allows the protagonist to actively participate in the necessary socialization, it is only his interior self that charts the course of his development.

Speaking of a similar tension in May Fourth realist fiction of the 1940s, Liu Kang points to the transition in the Chinese Bildungsroman, from a "dominant 'outer form' of critical realism" to an "emergent 'inner form' of subjectivity". This is an important shift, Kang notes, that indicates the inadequacy of revolutionary ideology in representing Chinese social reality, 
oscillating between a post-Bolshevik revolutionary euphoria and the paranoia of "white terror" after 1927. The inward turn of the Bildung as exemplified in the works of Lu Ling and Mao Dun, in fact, celebrates "the subjective fighting spirit" in an aesthetic form that is able to capture this dichotomy (Kang 69-70). Just as in Liu Ling's fiction the Bildungsroman mode reinstates the importance of individual subjectivity, in Shadows, too, it culminates in a similar reclaiming of the subject. Through such narrative acts of reclamation, the distorted Bildungsroman is able to reconcile the Northern Irish social reality to an essentially outmoded militant-revolutionary ethos.

Even though the novel must technically end with the protagonist's moment of epiphany it is drawn out till the consequences of his actions become evident. Joe has a philosophical insight that people were always, "mutilating themselves and each other in their desperation" (191). But his proper punishment, arguably, is to see such mutilation on the object of his desire, Kathleen. It is this final revelation that completes his alienation as the protagonist of the peripheral Bildungsroman. When he reaches Kathleen's apartment, he realizes that his brother's "friends" have already been there to "interrogate" Kathleen: "He wouldn't have recognized her if he'd see her on the street. Except for her clothes ... her hair had been cut short like a man's. Her face was swollen. One of her eyes was almost closed" (196). Joe is horrified by her disfigurement, and is unable to speak to her. He keeps stammering apologies, even as Kathleen moves about the room packing her suitcases, preparing to leave. The signs of physical violence apparent on her body reinforce his earlier thoughts of destruction.

Before leaving in her taxi Kathleen tells Joe that she had not wanted him to come. But she does have one last parting gift for Joe - a copy of $A$ Golden Treasury Of Verse. The gift is a symbolic one. It reinforces Joe's dream of becoming a poet. More importantly it demonstrates 
Kathleen's ability to forgive the damage done to her, and to leave with a message of optimism: “One day we'll see ... one day we'll forget it all. One day...” (198) Putting the book in his pocket, Joe starts for home to get his father a cup of tea. The ending scene is significant precisely because it leaves the question of Joe's future hanging in uncertainty. Joe's journey back home could signify anything; he could become an evolved individual who will act on Kathleen's message of optimism and rise above the violence around him. Or he could be living with a profound sense of alienation and regret for the rest of his life.

The narrative does not indicate anything concrete in this regard. This reticence suggests, as I have argued, the idea of a stalled or thwarted Bildungsroman. Joe's future is defined, in contradictory terms, by futureless-ness - indicated by his walk back home - to the point he had started from. Because Shadows remains an essentially political narrative about the Troubles, this ending helps to reinforce the lesson of misdirected violence and misplaced ideology on human character. There is no evidence to suggest what becomes of Brendan or Kathleen either: the other characters who embody youthfulness, and the possibility of change. The promise of "youth" is stalled by the intractable rupture in the very core of a society still struggling under the yoke of colonialism.

What makes Shadows such a unique study of the Northern Irish situation is the fact that in this novel almost every character can claim some form of victimhood. The female characters present diametrically opposite situations in this regard. Mrs. Logan's victimhood is obvious from the very beginning of the novel; Kathleen remains in denial of the dangers of her context, but in the end she too must face the consequences of trying to form human bonds beyond ideology. Mr. Logan and Brendan are largely grey characters. It is difficult to sympathize with them. Yet as Alfred McClung Lee observes, they represent a demographic that testifies to the destructive, 
emasculating effects of colonialism, the Catholic male "living on British dole in the Bogside, a 'Green' ghetto ... in Derry.” (46). If the idea of masculinity that Brendan and his father exemplify is problematic, it is also in part due to their historical disenfranchisement by British imperialism.

The questions that drive Johnston's characterization and plot construction in Shadows also resonate through Mahasweta Devi's Mother of 1084. Both narratives engage critically with political reaction, and the changed social roles of both men and women. Whereas Johnston carefully nuances her characters' relation to ideology, Devi projects it in decisive terms as good versus evil. For this reason, Devi's characters have less nuance, and are, more pronouncedly, either sympathetic to the "Movement" or not at all. This marks a difference in their social imaginaries as well. In Johnston's narrative, ordinary people suffer both from British military presence and IRA violence so that a nuanced approach becomes necessary. Devi's critique on the other hand is directed at the postcolonial Indian state, which is directly responsible for disavowing the needs of such a huge cross-section ${ }^{18}$ of its citizens. It is in this context that one must judge the success or failure of her adaptation of the Bildungsroman.

If Johnston describes a context where development is thwarted by misdirected violence, Mahasweta Devi depicts a situation where the transition from youth to maturity is cut short by a violence that is deliberate, cold-blooded and legitimized by the state. Despite hailing from very different geo-political spaces, their stories intertwine around shared concepts of youth, political

\footnotetext{
${ }^{18}$ The Naxalite movement started with a peasant revolution but soon it had incorporated industrial workers, urban based students, teachers, professors, other members of the intelligentsia, a large cross-section of the unemployed youth, working class populations, henchmen and also farmers and land laborers in rural India. For more details, see Dipankar Bhattacharya's "Trail Blazed by Naxalbari Uprising" Economic and Political Weekly 41.50 (2006): 5191-5194, and also Sumanta Banerjee's, "Beyond Naxalbari," Economic and Political Weekly 41.29 (2006): 3159-3163.
} 
violence and late-modern development. Like Shadows, Mother of 1084 may be read as an instance of a distorted Bildungsroman where the genre conventions are deliberately reconfigured to narrate a specifically peripheral reality. Instead of primarily revolving around a youthful protagonist, however, Mother of 1084 focuses an ageing mother who is forced to become the protagonist in place of her murdered son.

\section{Youth, Education and the Distorted Bildung in Mahasweta Devi's Mother of 1084}

Mother of 1084 was originally published as a Bengali-language novella, Hajar Churashir Ma ("Mother of 1084"), in the October issue of the periodical, Prasad, in 1973. Devi subsequently revised and published it as a full-fledged Bengali novel in 1974. Samik Bandyopadhyay, her long-time associate, translated it into English in 1997. The decade immediately preceding the publication of the work had seen one of the most volatile and turbulent periods in West Bengal's history. The Naxalite Movement, which had originally started as a peasant insurgency in the district of Naxalbari in North Bengal, spread to the whole of the state and indeed to many parts of the country, incorporating a large cross-section of the population. In the city of Calcutta, where Devi's novel is set, students, many of them still in their teens, led the movement. ${ }^{19}$ This group included young boys and girls from well-to-do families who joined the Movement, believing in armed revolution as the most potent way of fighting the social inequalities that had intensified after India's Independence. This is the political backdrop against which Devi's narrative is set.

\footnotetext{
${ }^{19}$ The Communist Party of India (Marxist-Leninist) was formally set up in 1969 under the leadership of Charu Mazumdar, who issued a special request to students to organize against the bourgeois educational system, and integrate with landless peasants and industrial workers for the collective "annihilation of class enemies". (Mukhopadhyay 2006: 3227).
} 
It is through the protagonist Sujata's memories that Mother of 1084 foregrounds the events related to the Naxalite movement, as it unfolded in Calcutta through the 70s. The powerful rhetoric of political agitation is riveted into the story, in the deeply "private" language of grieving and personal loss. It recasts the history of the Naxalite movement as the history of the excluded women, especially mothers, left to experience its bloody aftermath. In re-telling the narrative of armed struggle through the lens of maternal loss, Devi inextricably links the history of women's struggles of the period to that of the larger political agitation of the 70s. The experience of personal loss, and the process of grieving, thus become a journey towards political consciousness for her protagonist. It makes her a powerful orator against the inherent injustices of the system, which failed to account for the sudden and violent death of her son.

Mother of 1084 narrates the conflicted journey of the apolitical, upper-class housewife, Sujata. State-sponsored henchmen kill Sujata's son Brati, some two years before the commencement of the narrative. The plot outline charts Sujata's painful attempt to come to terms with her bereavement. Sujata's experiences after Brati's death compel her to re-evaluate her own lack of political awareness, which had led her to remain oblivious to Brati's involvement with the Naxalites. Her family's shame at having harbored a wayward son, and her husband's attempts to cover up their association with Brati, forces her out into the world of slogans, political pamphleteering and police brutalities all of which, Sujata discovers, were an integral part of Brati's universe. These experiences have a formative influence on Sujata forming the groundwork for her ideological "education".

The novel is divided into four separate segments by a specific time of day - Morning, Afternoon, Late Afternoon and Evening, each corresponding to a certain stage in Sujata's "education". This four-part structure, which covers a single day, forms the temporal unity of the 
novel. Despite being narrated in a stream-of-consciousness mode, in which the plot movement replies heavily upon Sujata's memories, the novel seems to follow a linear progression more familiar to drama. The day in question is the second anniversary of Brati's murder; brazenly, Sujata's family decides to throw an engagement party for their daughter Tuli. The insensitive act, meant to desecrate Brati's memory, outrages Sujata and causes her to break down before the guests.

By any definition of the genre (despite its many modifications), Sujata is an unlikely candidate as a Bildungsroman heroine. Yet, it is precisely because of her obvious limitations as a (female, middle-aged, apolitical, upper class) subject, that her "education" assumes importance in Mother of 1084. The irony of her situation as the putative protagonist is that she is a substitute subject, who must take the place of the more suitable subject, Brati, because the latter has met with an untimely death. It is important to note here that Devi does not bestow Sujata with a revolutionary or even rebellious ethos that would qualify her as the central character in a political novel. She "came from a rich family, an orthodox family. She had been put into Loreto College, made to do her graduation, only as a preparation for marriage ... Sujata held unquestioningly to all those values, comfort, security and all that went with them" (15). The sudden death of the son she adores dismantles the pre-destined gender role that Sujata had accepted without protest. It uncovers the need for self-evaluation and change, even at a mature stage in the individual's life.

On the morning of Brati's death anniversary, Sujata engages in a ritualistic recollection of his growing up years, trying to find a clue as to why he should have become a Naxalite. She tries to remember what books he used to read, in order to trace his ideological transformation into a revolutionary. Desperate for answers, she wonders if she was responsible in any way for his fate: "was there anything in the way she had brought up Brati that had made him into number 1084 in 
the decade that headed towards liberation? Or was there something that she could have done, or not done, to make him number 1084? Where did she fail?" (15). Sujata's questions indicate her striving to somehow implicate herself in Brati's sad end. It is both a matter of motherly pride, and a desire to somehow make herself part of a life that was clearly different from the normative, bourgeois lives of the others in the family. The course of Brati's Bildung, including his transformation into a radical Naxalite is lost to Sujata, whose ignorance of these matters did not allow her to see that her son was growing up to be a revolutionary.

Sujata's initial encounter with the rhetoric of the revolution occurs when the police raid the house to search through Brati's room. They find Naxalite slogans, written in Brati's handwriting. Sujata recalls seeing words that had meant very little to her: "The Prison's Our University ... From the Barrel of the Gun ... This Decade will be the Decade of Liberation ... Hate the Moderate, mark him, destroy him ..." (18). The words remind her of topical incidents of police crackdown on slogan writers. She remembers hearing that the slogans were first written on paper before being transcribed on the walls of the city. The discovery of the slogans in her son's bedroom is an indication to her, and the perhaps to the reader, that in a moment of revolutionary crisis, domestic space loses its supposed sanctity and separation from the public world. Instead of being concerned that the police was ransacking her home, Sujata thinks of the dangers incurred in writing the slogans on the walls at night, and the tremendous bravery of the youth who took on such activities.

Even though he is pronounced dead at the beginning of the narrative, Brati continues to dominate Sujata's consciousness until its very end. He is conspicuous by his absence, as his sister Tuli reminds Sujata. The latter remembers telling her son that he was changing. She was aware of a chasm widening between them; her son was "fast becoming a stranger" (16). This was 
as much a function of Sujata's lack of awareness as Brati's growing class-consciousness. He knew, she recalls, that she "could not understand what he said. He would treat Sujata like a child, would sound almost fatherly. Brati seemed to be pampering her" (16). This is a subtle change in the mother-son relationship, which is reconfigured by the son's ideological superiority over his mother. In retrospect, Sujata wonders, "why did it never strike her that when a son became a stranger to his mother ... even while they lived under the same roof, there could be a threat growing from it?" (17).

Sujata's reflections about her intellectual distance from Brati grounds the tension of political reaction within the limits of the family household. Sujata's concern stems from the fact that as the mother and as someone living under the same roof as Brati she could not understand him. Such a reflection seems to echo the writer's own concern about the lack of awareness among the middle-classes, especially women, about the reality of the Naxalite movement. This concern surfaces throughout the narrative and is, in fact, a determining element in the success of the Bildungsroman in Mother of 1084. Sujata can only understand her son if she engages with the implications of his ideology. It is important to note that Sujata's perceptions shape the plot of the novel in important ways. Devi never uses the authorial voice to dominate that of the protagonist, nor forces her own knowledge of the Naxalite movement on the reader. It is something the reader must discover along with Sujata, as she goes through her unique experiences on the streets of Calcutta.

Sujata realizes that Brati's death is of a unique kind: "If Brati had died in an accident, then the questions would have been different ... if Brati had paid the price of having been involved in a criminal offence, then there would have been the question as to who led Brati to comm. It the offence ... but Brati did not come under any of these categories" (17). As she tries 
to place Brati's death under a suitable category she realizes the impossibility of doing so. This is because his death is a testimony to the conflict between the dissident subject and the state. She concludes that, "all that Brati could have been charged with was that he had lost faith in the social system itself. Brati had decided for himself that freedom could not come from the path society and state followed. Brati had not remained content with writing slogans on the wall, he had committed himself to the slogans" (18). It is a testimony, for the grieving mother, of the violent contradiction between democracy in theory and in practice.

The fact that she could not perceive Brati as a criminal under any definition of law or circumstance opens Sujata's eyes to the true nature of state repression. This is a new perspective, which shows that social integration and citizen status depended on the uncritical acceptance of state policy, even if the policy was based on corruption and inequality. Sujata realizes then that Brati was different from, "profit-mad business men and leaders blinded by self-interest," who had been taken under police protection. For rebellious youth, like him, who had channeled all their youthful energies into social reform, death was the inevitable outcome: "They were all sentenced to death. Anybody was permitted to kill them. People in all the parties, people of all creeds had the unlimited, democratic right to kill these young men ..." (20, emphasis added). Dissident, rebellious youth could not be accommodated in a society bent on serving the interests of "spineless, opportunist time-servers" (17). They had to be eradicated because, "once this loss of faith assailed a boy, an adolescent, or a youth, it does not matter whether he is twelve, sixteen or twenty-two, death was his portion" (19). In a situation where age is only of secondary importance for an individual to be socially outcast and punished, youth no longer serves as a necessary element in a "classic" Bildung type development. 
Sujata's reflections on state violence are concretely reminiscent of the reaction of the police, and their role in brutally suppressing the movement. Describing the unregulated powers exercised by the police force in 1970s Calcutta, the historian Ashoke Mukhopadhyay writes “... the unchained police force was adequately encouraged to liquidate Naxalites through 'encounters'. The sole motive was to kill the enemy by any means. The legal procedures were given a go by. On getting a green signal from the top [the government], a section of the police force happily turned Calcutta and its suburbs into their hunting ground" (3230). Sujata's growing awareness of the brutality of a "legitimate violence," to counter and delegitimize the violence of those who believe in the cause of revolution, enables her to interrogate the very nature of democracy. As a protagonist, Sujata becomes the arbiter between the author, and a specifically middle-class readership that might not be familiar with the modus operandi of the police force. Devi's purpose here, I would argue, is to reach out to this readership with a plea to reflect upon established notions of democracy, and liberalism.

Mother of 1084 posits a symbolic youth, encoded in the idealistic protagonist Brati, where ideas of nation-formation may be tested. The process of Brati's "coming-of-age" had indicated to Sujata that he was not like the other members of the Chatterjee family. He "would not act the way they acted ... would not follow in their footsteps even when he grew older ... And so Brati belonged to the other camp (30). This conceptualization of youth as a revolutionary force dooms its bearer to an early death, since it can have no legitimate space in the fabric of the new nation. It is a youth that must be annihilated at the very moment of its transition into maturity, so that the equilibrium of a corrupt, unequal state is sustained. Even as she ponders the rationale behind Brati's death, Sujata begins to compare her own ideas to those of her son, and 
her own middle-class complacency with his rebellious tenacity in breaking rules. The process of grieving thus becomes a crucial step towards Sujata's transformation.

A corrupt state and a corrupt family coincide to become part of an elaborate, institutionalized, and socially legitimized process of domination. Sujata's own family is depicted without ambiguity as a social unit where such corruption is lived out as everyday normalcy. Sujata's husband Dibyanath has relationships outside marriage, her daughter Tuli cares more about table manners than her mother's feelings of her mother, and her obedient elder son pays homage to his father. From the moment Sujata receives the news of Brati's death, her family becomes an alien force: a group of people she lives with but cannot identify with on any grounds. Sujata's family reflects the attitude of the state, rejecting Brati when he was alive, and then desecrating his memory by going on with their comfortable existence as if nothing had happened. Sujata's alienation from her own family propels her into a journey towards selfdetermination along Brati's revolutionary path, as an alternative to the hypocrisy of the rest of the household.

The first section of the novel, titled "Morning" underpins the process of Sujata's radical transformation, beginning with her perceptions about the family. Sujata's family collectively disavows Brati's sacrifice when the news "bursts upon the neat and clean household ... with a violence that did not fit into any pattern" (Devi 6). Brati's father, Dibyanath Chatterjee, is determined that his son's association with the Naxalites is not allowed to mar the family name: "they were all prudent people, they lived by the laws of the land, they were good citizens" (7). Fearing scandal, Dibyanath does not even allow Sujata to take his car to the Kantapukur morgue, where Brati's body was kept for identification. It is more important to him, she recalls, that his car should not be identified. Soon after receiving the news, Sujata's husband begins to remove 
all signs of Brati's existence from the house including objects of his everyday use - his shoes, his raincoat and even his photographs from the wall. He has to "pull many strings to hush up the news that his son had died such a scandalous death" (7). Because of Dibyanath's elite networks and through his active effort, Brati's name does not appear in any of the newspapers the following day. Dibyanath's attempt to wipe out the very existence of his revolutionary son is telling in the way it exactly mirrors the attitude of the state, essentially one of total eradication.

This contradiction is also visible in the values represented by the male members of the family. Sujata's husband Dibyanath has his own accountancy firm. Her elder son Jyoti works in "a firm with a British name”. His father-in-law lived in Britain. Tuli’s fiancé, Tony Kapadia was in the business of exporting, "Indian silk batik, carpets, brass Natarajas and Bankura terracotta horses" (6) - cultural artifacts from India that are in demand in the "West". Not only is there an implicit continuation of colonial era business in the family, there is also the emerging practice of marketing "postcoloniality" as an exotic commodity where it is in fashion. Brati offered a contrast, in Sujata's mind, to such modes of model masculinity. He represented an enigmatic and unpredictable force that she is not able to grasp even in her dreams. She realizes that it only through an implicit rejection of the family, and a simultaneous embracing of life on the streets, that she could grasp the alternative way of being that Brati represents.

The section titled "Afternoon" describes the second stage of Sujata's development. It comes from her meeting with the impoverished family of one of Brati’s comrades, Somu. Somu's family, especially his mother, witnessed Brati’s revolutionary life from close quarters. Brati would often come to their shabby dwelling along with the other Naxalites to spend an evening or the night under their roof. When Sujata meets Somu's mother for the first time, the visual difference between them is striking. In contrast to Sujata's crisp and pristine attire, Somu's 
mother's clothes are dirty from the grime of poverty and domestic chores. But Sujata finds her company desirable because she represents a perspective outside of her own social milieu and class position. Somu's mother talks about the time she spent with Brati and the other boys at their little cottage, reinforcing a fresh wave of guilt over Sujata. She does not (could not) share the same sense of camaraderie with her son or his friends and never got the opportunity of getting to know them closely.

Somu's family provides a sharp juxtaposition with her own. Their very presence in the narrative testifies to the deeply entrenched class inequality of postcolonial India. Devi's description of the "colony" [settled spaces usually at the city limits] in which they live is unapologetic and unflinching. It reflects the government's step-motherly attitude towards the urban underclass. The colony had grown organically, out of swamplands and marshes, where post-Independence immigrants settled down. These were neglected areas that did not figure in any plan. The government had "taken its revenge by denying the region the simple comforts of a decent road, a health center, an adequate number of tube wells or a bus route. Those who had grown rich in the last two decades in the region itself had not cared to do anything for the area" (33). The colony is a testimony to the corrupt governmental practices that Brati and his comrades were trying to battle.

Brati's affinity with Somu's family suggests her implicit rejection of the bourgeois family home. At the time of the Naxalite movement, the anthropologist Henrike Donnor writes, the rejection of the family was an important part of Naxalite identity, especially for young boys from relatively privileged backgrounds. Rejection of the bourgeois family was a way of establishing one's "credentials" as a movement cadre. As Donnor correctly notes, the biological family was often replaced by an ideological family of likeminded individuals operating outside the paradigm 
of social mandate: "In the Naxalite movement, young men formed very strong bonds with comrades their own age, both, male and female, but also with older men. Young activists were often recruited by a teacher or professor, and they turned their back on their families when they entered into close relationships with these figures of authority" (332). In relocating the motherson relationship as a site of ideological rather than familial empathy, Devi in turn suggests that the extended family might become a space of belonging for older revolutionaries, and mothers.

Listening to Somu's mother opens up a new world for Sujata; she wonders that, "Brati had built another Brati with his beliefs, his ideals and ideology. This other Brati loved his mother; his mother loved him, but never really knew him. These boys knew the other Brati, the Brati that Sujata did not know" (57). Sujata's ritualistic rendezvous with Somu's mother is part of her mission to rediscover her son through a metaphorical "knowing". But it is also a transformatory experience that releases her from her private grief, and helps her understand that there were many others in fact who share the same loss. The killing of Brati and his friends after all had larger political implications that went beyond her personal loss: "Sujata remembered having seen a number of dead bodies in the morgue ... at the time she had not understood how those corpses ... were connected, were one with her. Now she realized that Brati had belonged with them not only in death, but also in life" (57).

This newly acquired worldview marks the next step of Sujata's journey - the visit to Nandini, Brati's comrade-in-arms and love interest. Sujata's meeting with Nandini, in the short section titled "Late Afternoon," is replete with tension; Nandini recounts details of her horrible experience of police brutality. "Just as news reports of the killings were carefully shielded from publication, the groans and screams of pain coming from the tortured interviewees too would be absorbed by the walls of the soundproof interrogation room. The police shone glaring lights into 
the feeble, unaccustomed eyes of the arrested revolutionary and thrust burning cigarette butts into their skin". It was this lack of knowledge, Nandini points out vehemently, that had come back to Sujata causing a violent shattering of illusions: "now you know that it's wrong to carry on presuming that one needn't know why and how such things happen" (72).

Nandini is presented in the story as a foil to Sujata, who has always lived in the privilege of ignorance and indifference to politics. Nandini represents a relatively unacknowledged demographic - that of the female revolutionary. Through her portrayal of the courageous Nandini, Devi uncovers the little known world of the female guerilla, whose participation in political agitation is often considered secondary to that of the male leadership. As Srila Roy writes, female Naxalites (such as Nandini0 were often fairly ordinary women who, "left the sphere of the everyday, going underground to lead fugitive lives, participating in the highly male culture of the New Left" (2). Nandini leaves Sujata spellbound with her tenacity and her revolutionary commitment, even after being brutalized by the police and losing the man she loved, Brati. As Sujata leaves, she realizes that the effects of this brief encounter were to stay with her forever, helping her piece together all the information she had received.

This last encounter with Nandini marks a crucial turn in Sujata's "education". Nandini's reference to the physical tortures she had experienced harks back to Sujata's experience earlier at the police morgue. She had been summoned to identify Brati's body. His corpse, like the many others exterminated through state violence, bore the marks of its rough justice: "There were three bullet holes on his body, one on the chest, one on the stomach, one on the throat. Blue holes. The bullets had been aimed from close range. The skin around the holes was blue. The cordite had left its burns. Chocolate colored blood. The cordite had scaled the skin around the hole to leave it parched and cracked into hollow rings" (11). The vividly detailed and gory description of the 
mutilated body of Brati not only exposes the brutality of state violence, but also underlines the lasting impact of the horror on Sujata's memory.

The graphic memory of the battered and mutilated body of the revolutionary son is juxtaposed against Sujata's growing awareness about the shallowness and falsity of the dominant discourse of normalcy. Sujata's recollection of the state of Brati's body is thus also a revelation of the inherently diseased body of the state. This is a moment that captures the troubled historicity of motherhood in which Sujata finds herself implicated. Brati's dead body, marked only by a number - 1084 - embodies within itself the narrative of Sujata's evolution from an apolitical and passive object, to a "terrifying" citizen subject who now sees herself not just as Brati's mother but as the quintessential mother - the mother also of the 1083 other revolutionaries who had died unacknowledged, like Brati.

Postcolonial feminist scholars like Mrinalini Sinha, Tanika Sarkar and Lata Mani have repeatedly turned their attention to specific constructs of "womanhood" that dominate the national imagination, particularly that of the "mother land/domestic goddess" ${ }^{20}$. Tanika Sarkar for example, draws attention to the deeply entrenched patriarchy that is evident in the popular imagination of the $19^{\text {th }}$ century, Hindu revivalist polemic of Bankimchandra Chatterjee, ${ }^{21}$ as well as later in Mohandas Gandhi's patronizing formulation of the woman as the "ideal satyagrahi" or political subject by virtue of her "moral resistance strategies and meekness" (Sarkar 7). While

\footnotetext{
${ }^{20}$ See Tanika Sarkar's Hindu Wife, Hindu Nation: Community, Religion and Cultural Nationalism (2001); Lata Mani Contentious Traditions (1998); and Mrinalini Sinha's Specters of Mother India: The Global Restructuring of an Empire (2006).

${ }^{21}$ Tanika Sarkar traces three different facts in Bankimchandra Chatterjee's construction of the state of the "Mother" - the past, where the motherland is in the glorious state of abundance and benevolence, the state of "Kali" or the goddess of death who symbolizes her fierce, terrifying present form, and the final state of "Durga" who combines the benevolent nurturing image with that of tremendous power and positive energy. See Sarkar, Hindu Wife, Hindu Nation (pp 254256).
} 
Mahasweta Devi consciously departs from the elitist, Hindu, male representations of Indian womanhood, she also critiques and subverts the patriarchal logic of such representation. The construct of "motherhood," in particular, becomes a fraught site of overdetermined symbolism on one hand, and violent disavowal on the other.

The metaphorical association of motherhood with a number (corpse no. 1084) in Devi's novel both subverts the nationalist glorification of motherhood, and concretely situates it in terms of the death rather than the birth of the putative citizen: the de-legitimized son(s). In Mother of 1084 the relation between youth and a post-colonial modernity is not ideologically analogous, but in fact mutually contradictory. The death of the protagonist that represents youth and progressivism transfers the onus of change back to the mother, thus complicating the idea of an iconic motherhood that derives validity solely from the reproducing and nurturing of the male nationalist subject. The violent, symptomatic turning back from son to mother in Devi's novel indicates regression rather than progress that also disrupts, as I have argued, the linear developmental paradigm of the Bildungsroman.

The end of the narrative shatters all of Sujata's illusions. She is able to see through the fundamental paradox of a society that is attempting to maintain a shallow veneer of normalcy. She reflects that, "while the Bratis were being killed in the prisons and on the streets ... the conscience-keepers of society had not a word to say about them" (60). With some amount of detached wonder, she thinks about the apparently mundane reporting in the newspapers that maintains a façade of normalcy: "the gold rates had gone up as usual, the banks in Calcutta had transactions worth crores of rupees, an elephant cub was flown from Dum Dum to Tokyo ... a festival of European films opened in Calcutta, the radical artists and intellectuals of Calcutta demonstrated against barbarities in Vietnam ... The deadly risks that the youth of West Bengal 
faced cannot have been important enough. If they had ... wouldn't the artists, writers and intellectuals ... have picked up their pens?" (50).

By this point Sujata's alienation encompasses not just her family but civil society as a whole. Through its demonstrations of solidarity with other countries, such as Vietnam, the nation's intellectuals try to maintain an image of stability, harmony and success, when it is obvious that India itself was undergoing a very real political crisis in the form of the Naxalite movement. This collective nonchalance finds an immediate resonance closer to home, when Dibyanath decides to throw an engagement party for Tuli on the same day as Brati's death anniversary. Despite the general knowledge of the significance of the day, Sujata is asked to be present at the occasion. It is the litmus test of her motherhood: a challenge for her to give up her obsession with Brati, and to embrace the world of "the living". Sujata decides to play her part. Despite feeling the terrible pain of her sore appendix, she decides to be present at the party, and witness the self-centered actions and words of her family who articulate an implicit relief that, "the man who had messed up their charming social game [meaning Brati] was now dead" (Devi 29).

This collective betrayal of Sujata's family culminates in the arrival of Saroj Pal - the police officer who had been at the head, of a "massive investigation, search and punitive operation" launched by the state against the Naxalites. Sujata remembers the very words of the "suave and sophisticated" police officer who had justified the death of her son, saying, “... Mrs. Chatterjee, your son lied to you ... Misguided youth! Yes, a cancerous growth on the body of democracy" (29). Saroj Pal had been invited to the party at their house as a special friend of Tuli's fiancé, Tony Kapadia, exporter of antique goods. Sujata looks at Saroj Pal, in his uniform, and a surge of questions flood her mind. She wonders, "Did Brati die so that these corpses with 
their putrefied lives could enjoy all the images of all the poetry of the world, the red rose, the green grass, the neon lights, the smiles of mothers, the cries of children - forever? Did he die for this? To leave the world to these corpses?" (125).

Sujata's perception of the people making merry around her as "corpses," inverts the categories of the dead and the living. It indicates the complete and utter alienation of the mother who has arrived at the painful realization of the hollowness and meaninglessness of her son's untimely death. As Sujata looks around her she sees, "a society that gave the dead the right to live, and denied it to the living". She had been suffering from a diseased appendix for a while, now the pain tears through her body as she attends to the guests. Her elder son, Brati's brother, had put on "a frenzied jazz" (123): the music disorients her. Dwelling on her thoughts and unable to bear the physical pain as her appendicitis bursts, Sujata collapses on the ground, crying out Brati's name. Her cry is one final gesture of refusal; it "bursts, exploded like a massive question, spread through all the houses of the city, crept underneath the city, rose to the sky. The winds carried it from one end of the state to another, from one corner of the earth to the other, to the dark piles and pillars that stood witness to history" (Devi 127).

The bursting of the appendix at the end of the novel articulates a powerful, almost atomic imagery in which the explosive cry of pain metaphorically engulfs both space and time. The comparison here of Sujata's cry with a "question" is significant, since most of her previous questions, like her appendicitis pain, had a temporary cure; they had been nagging her throughout the novel, even disrupting the flow of her thoughts and of the plot. The final questions plaguing her mind just before the catastrophic event however, are related directly to the legitimacy and purpose of Brati's sacrifice and that could only be answered through the violent disruption of the narrative of normalcy. The internal bursting of the festered organ seems 
to reveal, with poignant accuracy, that society itself is diseased and festered, the people pretending to be normal, only "corpses," while Brati's mother had once again recalled his name into the world claiming for him, a heroic deathlessness.

The passage of historical time in Mother of 1084, marked by the four segments in the novel, in fact ruptures the linearity of the developmental mode of the Bildung. This rupture is aptly summarized by Sujata who perceives this passage of time as a threat to her memories of Brati: "Time was stronger than grief. Grief is the bank, Time the flowing river, heaping earth upon earth on grief ... Then a time comes when nature, with its ruthless logic, throws up new shoots out of grief submerged under the alluvium of time ... Shoots of hope, sorrow, thought and hate" (61). Besides referring to the temporal movement of the plot, this mode of reflection also indicates a moving forward from the ritualistic practice of "grieving," to a more educated and holistic perception of the event. The imagery of shoots emerging from a buried grief is also an image of regeneration and development, which in fact, mimics the structure of the Bildung itself.

Like the teleological reference of the novel the unfolding of the Bildung also corresponds to a corresponding emotion crystallized in Sujata's rumination as "hope, sorrow, thought and hate" (61). In the first stage of her recollections Sujata remembers a "hopeful" time when Brati's childhood and adolescence reassured her of the shared human intimacy that she never received from the rest of her family. This maternal "hope" is rudely shattered by the sudden and unforeseen "sorrow" of his violent death, which comes across in the first half of the narrative. The next dominant emotion maps the next stage of Sujata's education through sustained and critical "thought" about Brati's ideology, about the meaning of his slogans, his cryptic prophesies of revolution, her own maternity and the role of the family. This significant stage leads to the culmination of Sujata's development as a politicized subject who is able to "hate" the 
class enemy - not for her personal loss - but for their collective betrayal of the ideals of revolution.

\section{Conclusion}

Comparing Mother of 1084 to Aranyer Adhikar (The Rights of the Forest), a historical narrative about the Munda insurrection which Devi was working on around the same time as the novel, the noted critic Gayatri Spivak points to the "significant change" visible between the two. The latter text, Spivak argues, is "a meticulously researched historical novel". By contrast, Spivak finds Mother of 1084 restricted, "within the excessively sentimental idiom of the Bengali novel of the last twenty years" (1987: 383). The reason that Mother of 1084 may come across as "sentimental" is made evident in Spivak's own insightful acknowledgement of the relative difficulty of speaking from, "our own academic and First-World enclosure" (383). This is a space where a text that has been meticulously researched and historically grounded, such as Aranyer Adhikar, has greater value, both as a literary work and as repository of "information" about significant historical events in the periphery.

What Spivak appears to misread, of course, is the usefulness of the "sentimental idiom" as a political mode in Devi's representation: of what was the last, urban phase of the Naxalite movement before it (temporarily) faded out of the Indian political topography. The metaphorical "mourning" of the main character of the novel for the dead revolutionary acts as a symbolic register for what is necessarily a historical process - the end of an era of radical, political transformation. Devi does use the familiar Bengali (indeed nationalist) idiom of sentimentalizing the mother-son bond. The figure of the grieving mother and her sacrifice of the wayward son are staple literary motifs in the works of mainstream Bengali male writers, like Premedra Mitra, 
Subodh Ghosh and Samaresh Bose, as well as in the fiction of stalwarts before them, Sarat Chandra Chattopadhyay, Bibhutibhushan Bandopadhyay etc. In Devi's recasting of this relationship, such sentimentality is invoked: only to be substantially rejected by the radical motherhood of the politicized female subject.

Spivak's repudiation of the novel's political potential also rests upon the text's markedly middle-class ethos, as opposed to the radical alterity of the tribal narratives for which Devi is better known. But it is this very ethos that, as I have argued, makes Mother of 1084 a radical work of domestic fiction. It reconfigures the Bildungsroman mode to test the limits of a liberal, bourgeois ideology. All of Sujata's experiences, including her initial inability to decode the slogans on the walls, her encounter with the family of the poor revolutionary, her meeting with the female Naxalite guerilla Nandini, uncover the limitations of her character for the reader to learn from them. Sujata herself keeps "learning" about them as the novel unfolds, suggesting a Bildungsroman type trajectory of evolution, growth, and character-formation. The middle-class setting becomes a launching pad for the critique of liberal ideology.

Finally, as novels that emerge out of historical moments of crisis, Devi's Mother of 1084 and Johnston's Shadows share several formal and thematic overlaps. One of the most prominent formal convergences is in their implicit adaptation of the popular mode of political theater. Mother of 1084 was, of course, re-conceptualized as a play by the author herself. Shadows, on the other hand, bears echoes of Irish political theater, particularly the work of Sean O'Casey. It is noteworthy that much of the violence described in the novel in fact takes place beyond the actual pages of the text, just as in theater it might take place off-stage. Moreover, ideological debates among characters are mostly staged in enclosed domestic spaces - the Logan family kitchen, 
Kathleen's apartment etc. Structurally, Johnston seems to be borrowing a form and setting popularized by O'Casey: the domestic space of the Catholic working-class home.

Because domestic spaces are so crucial to the structure and form of the political novel, their representation of women often replicate those of a nationalist iconic femininity. In Johnston and Devi's novel there are two generations of women: the mothers and the love interests, and each of them both confirm and complicate nationalist ideas of womanhood. If Sujata is the revolutionary mother who adopts her son's political ideals to transform her own self, Mrs. Logan is the more skeptical mother who attempts to transform her idealistic but flawed son, Brendan. As a working-class woman, Mrs. Logan has very little belief in political ideals of any kind. Sujata, who has a comparably more comfortable existence, is able to look upon the movement with much more empathy and understanding. Mrs. Logan fulfills the well-defined cultural prototype of the self-sacrificing maternal figure. However, she also exhibits her agency by challenging her son's idea of a "revolutionary" nationalism. Sujata on the other hand is a passive, apolitical individual who goes on to embrace a revolutionary ethos. In both narratives, there seems to be a play on the mother-son relationship that deviates consciously from mandated narratives of cultural nationalism.

Kathleen, the other female figure in Shadows has resonances with Nandini, Brati's love interest and fellow revolutionary in Mother of 1084. Both are unencumbered by familial ties, and both form a close relationship with the main male character. Unlike Nandini, however, Kathleen's social role remains ambivalent throughout the narrative. Despite being tortured by the IRA, she holds on to her optimism about being able to transcend the crisis of her context. Nandini advocates a different kind of optimism, as she emphatically reminds Sujata that the movement has not died with Brati: that it will continue until concrete social changes come about 
(86). These female characters highlight two very different social imaginaries at work. In Devi's context, political violence is a legitimate tool of social transformation. It can effect real, palpable changes. It is something that the youth represented by Brati and Nandini have invested their entire lives in. Johnston, on the other hand, demonstrates the dangers of misdirected violence that has very real consequences for those like Kathleen who are unable to judge its destructive power.

The Bildungsroman mode provides a valuable formal structure against which the male characters in the two novels may be understood. Devi's hero is almost larger-than-life, a model revolutionary: while Johnston's protagonist, Joe, inhabits the opposite end of the spectrum. But they both ultimately remain products of an uneven and asymmetrical development at the periphery. As an active revolutionary Brati has more in common with Brendan than Joe, yet Johnston portrays Brendan as an extremely shady character whose ideological commitment to revolution is as questionable, as his social role as a son. Brati by contrast is an exemplary son and revolutionary - he does not go undercover for the sake of his mother's happiness, and becomes a martyr to save the lives of his compatriots. Joe, who realizes the futility of misplaced ideology, provides an example of a new form of youth disillusioned by the state and the movement alike.

While the conflict in Northern Ireland has garnered its own share of unwelcome media attention especially in the "West," over the last several decades, the Naxalite Movement has remained curiously underrepresented. Such contrasting "visibility" has shaped the corpus of literary production very differently in both cases. The representation of Northern Ireland in "tragic" terms by the international media for example, may be connected, according to Joe Cleary, to the predominance of the genre of domestic tragedy especially in Northern Irish drama (2007:233). Similarly, the generic forms of memoir, autobiography and political narrative (rather 
than fiction) have dominated the literary landscape of the Naxalite period in India. Although a substantial body of vernacular literature on the Naxalite movement has been archived and studied, only a fragment of it has reached a global audience; this includes the majority of Mahasweta Devi's own writings on the subject. By re-situating Johnston's Shadows and Devi's Mother of 1084 as studies on the late-modern Bildung, I uncover the complexity of selfdetermination in the world's most politically turbulent contact-zones. 


\section{CHAPTER FOUR}

\section{MAKING IT 'BIG': KIRAN DESAI'S THE INHERITANCE OF LOSS AS A NOVEL OF GLOBALIZATION}

Slowly, painstakingly, like ants, men would make their paths and civilization and their wars once again, only to have it washed away... (The Inheritance Of Loss, 323)

Globalization theory has been an important determinant of recent debates on global literature, as well as an extension of contemporary postcolonial theory (Deckard et al, 2015). While the noun form of the word 'globalization' is suggestive of precisely such an etymological continuity, the exact meaning and scope of the word, remains ambivalent. As Revathi Krishnaswamy observes, globalization theory and postcolonial studies have come to share a "cultural grammar" of umbrella terms like hybridity, migrancy, cosmopolitanism, local/global, terms that are frequently invoked but never clearly defined (Krishnaswamy 3). The insistent use of these vaguely defined and much contested terms undermines the nation-state as a site of identification. Such identification may be reinstated through a critical return to the nation, I wish to suggest, not as a primordial given, but as a mediator between global political and economic adjustments and lived everyday experience, of the national subjects and non-subjects alike.

When postcolonial literature "goes global," seeking what Arjun Appadurai terms as a "radical break with the past" (1996), it also involves a concomitant disengagement from inherited narratives of nation building. The themes of uprootedness, displacement and the breakdown of the traditional family emerge as recurring themes in narratives of individual self- 
fashioning; these are often counterpoised against older, collective struggles for social transformation. Such a body of literature complicates what one means when one invokes the category of a "postcolonial or global literature" since it (often unwittingly) registers the crisis of globalization ${ }^{1}$ rather than its success. The literature produced in the periphery and consumed in the metropole is thus often uniquely positioned, to nuance and reconfigure the structural incongruities of the nation as well as to illuminate the aesthetic categories of a sophisticated and highly corporatized global literary market.

Through the invocation of multiple locations and histories, Kiran Desai's Booker prize winning novel The Inheritance of Loss (2006), foregrounds the uneven interaction between the local and global. The novel encompasses three unique and critical moments in India's national history - the colonial period, the Bandung era ${ }^{2}$ and the postcolonial moment of the late 80 's. Each of these historical junctures posits a specific story of migration; uncovering an uneven experience of modernity. The colonial narrative revolves around the judge, Jemubhai Patel, one of the main characters who had struggled to build a life in imperial England before returning to India to live with his granddaughter Sai. Sai's parents, who had travelled to the USSR to

\footnotetext{
${ }^{1}$ See also Simon Gikandi's "Globalization and the Claims of Postcoloniality" The South Atlantic Quarterly 100.3 (2001): 627-658. Exploring the relation between the concepts of globalization and postcoloniality Gikandi argues that the discourse of globalization seems to be caught between two conflicting narratives - one of celebration, the other of crisis. The paradigm of crisis is more visible in peripheral spaces that are unevenly developed.

${ }^{2}$ The 1950s is generally referred to as the Bandung era, since it witnessed the successful negotiation of non-Alignment pioneered by the Indian Prime Minister Jawaharlal Nehru. The Bandung Conference (1955) marked the glorious emergence of the so-called "Third World" from centuries of colonial oppression. The 50s also marks the beginning of a long period of scientific, military, cultural and political collaborations of India with the Soviet Union. For more details see Neil Lazarus' The Postcolonial Unconscious. New York: Cambridge University Press, 2011 and Samir Amin et al.'s Beyond US Hegemony: Assessing the Prospects for a Multipolar World. London: Zed Books, 2013.
} 
participate in the Indo-Russian Space program, ${ }^{3}$ represent the short lived optimism of the postIndependence era. Their accidental death leaves Sai orphaned and the judge in a state of even greater self-abjection. The third instance of migration is provided by Biju, the son of the judge's cook Panna Lal. Biju's is a particularly poignant story of an underclass, illegal immigrant in the US - who unlike the judge and Sai's parents - belongs to the invisible labor pool that travels to the First World on the elusive promises of a better life.

Biju effectively realizes the migrant's dream of border crossing, but as a restaurant cook working illegally in New York. He is submerged in the underbelly of the global city, a peripheral figure floating at the margins of the "new" metropole. He is inside the "West" yet outside it. The other protagonist, Sai, a young, globally mobile, privileged Indian woman, gets caught up in her homeland in an indigenous insurgency that is still trying to assert its autonomy from the Indian nation-state. Exploring a familiar theme of the contemporary Anglophone novel - the underdog's dream of making it big in the globalizing world - Desai's novel interrogates the (gendered) conditions under which some subjects cross borders and others do not. Represented by such marginalized characters as Biju, Gyan, Sai's Nepalese tutor and Biju's father Panna Lal the novel forefronts the lived reality of subordinated groups who are denied any direct access to the privileges of social and economic mobility. The plot of the novel, then, critically parallels the circuits through which literary texts (and relegated narratives) circulate in the Anglophone marketplace.

\footnotetext{
${ }^{3}$ The reference to the Russian Space program in The Inheritance invokes an interrelated but little known history - that of India's strategic political, economic, and military relations with the Soviet Union from the post-Independence years through the 80's. For a detailed study of the political significance of this relation to India, see Rajan Menon, "India and the Soviet Union: A New Stage of Relations?" Asian Survey 18.7 (1978): 731-750. See also, Anita Inder Singh's "India's relations with Russia and Central Asia." International Affairs 71.1 (1995):69-81.
} 
In the secondary literature on globalization, multiple scholars have emphasized the need to uncover the material effects and implications of an uneven globality (Dirlik 2004; San Juan 2004; Parry 2004; Lazarus 2011; Esty 2013). They call for greater attention to the structural asymmetries of the globalizing process. Benita Parry, for instance, closely aligns globalization with imperialism as “capitalism's accelerated penetration of the non-capitalist zones” (108). This entails recognizing, in other words, that the uneven interaction of globalization (as imperialism) with pre-existing social asymmetries in differently decolonized or decolonizing contexts creates multiple, yet similar, forms of uneven development. Even as current forms of globalization seemingly adopt even more complex and sophisticated economic practices, these remain fundamentally imperialist in orientation. By contrast, the sociologist Leslie Sklair identifies three main differences in current modes of globalization from earlier colonial phases of capitalist expansion: first, technological and organizational changes leading to accelerated goods production; second, the political organization of capital on a global scale; and third, the wide circulation of (media-) ted images that sustain ideas of a hegemonic globality in the popular imagination - an argument also endorsed by the anthropologist Arjun Appadurai (215). ${ }^{4}$

If Sklair and Appadurai draw attention to the economic and cultural effects of globalization, respectively, Mariano Siskind highlights its relationship to literature, specifically to the novel. Siskind elaborates on the canonical work of Georg Lukács on the nineteenth century French, Russian and German novels but with explicit focus on the colonial peripheries. Referring to the interrelated history of the rise of the novel in Europe and that of colonial capitalism, Siskind underlines the novel's suitability in producing "privileged and efficient narratives of the

${ }^{4}$ Appadurai describes the ubiquity of media images of a globalized public sphere, as one of the main factors contributing to the spread of globalization. This results in the local appropriation of global practices, or "glocalization," leading to the idea of the expansion of globalization (See Arjun Appadurai 1996: 4). 
global formation of a bourgeois world" (337). The European novel as a genre is deeply implicated, according to Siskind, in conceptualizing the "global totality" of a bourgeois capitalist modernity as a world-historical process. Novels of globalization on the other hand, produced from and about the periphery, highlight the fault lines in such a projection of global totality by emphasizing the uneven material logic of globalization. They present narratives illustrating what Siskind very aptly terms "the globalization of the novel" but with distinct peripheral characteristics.

Particularly since the rise of academic postcolonial theory in the 1980s, the "novel" in India has evolved dramatically both in form and content. As Pranav Jani points outs, novels from the postcolonial era of the 50's and 60's demonstrate a marked difference in ideological orientation from the novels of the 80 's onwards. If the former exemplify a return to the nation and to a subaltern sensibility in the form of a namak halal (true to the salt) cosmopolitanism, the latter celebrates rootlessness and ambiguity of belonging (Jani 17). Jani defines this as the "postnational" text that embodies multiple "cosmopolitanisms" - a trend inaugurated by the global success of Salman Rushdie's Midnight's Children (1981). Jani's argument, although elaborating a useful framework for analyzing the rise of the novel form in India, does not fully register the implications of the uneven trajectory of historical development. His proposition may be nuanced with the claim that the Indian novel in English, as a distinctly peripheral genre, never quite achieves a fully "post-national" identity. Because of the continuity of residual or foundational structures in the underdeveloped periphery, a complete disengagement from the nation and national formations becomes impossible.

The Inheritance of Loss launches the search for an alternative modernity only to dismantle such a possibility. The crisis of an uneven history surfaces in multiple thematic strands 
in the novel ensconced in the idea of progress and social mobility. The backbreaking struggles of the underclass migrant worker Biju remains unrewarded; his rootlessness and alienation can only be overcome through a (physical) return to the nation. Similarly Gyan, an unemployed youth inhabiting the periphery of India's North-East, experiences an equally compelling rootlessness and alienation in a nation with which he struggles to identify ideologically. For the marginalized populations therefore there is no "alternative" modernity, but one which is inherently uneven and incongruous. For them individual desire, specifically the desire of disengaging from inherited structures of existence, simply does not exist.

Even as the novel posits, in no uncertain terms, the paradoxes of uneven development, it also foregrounds the significance of human struggle for autonomy and emancipation. A significant section of the narrative invokes the complex history of India's North-East region which has experienced sustained political instability since Independence. The Gurkha insurgency ${ }^{5}$ in which Gyan becomes an unwitting participant recuperates a relegated history of postcolonial India - the marginalization of ethnic minorities within the country. The disparate insurgency movements and struggles for autonomy among the many smaller ethnic groups in the North-East have exacerbated the history of Indian nation-formation. The postcolonial state has, in turn, deployed the severest counter-insurgency measures in the region including the deployment of heavily armed military and paramilitary groups. The Indian state has moreover

${ }^{5}$ The Gorkhas or Gurkhas have been involved in militant nationalism against the Indian State for a long time, their main demand being that of a separate Gorkha state in the Indian North-East. The British policy of recruiting Gurkhas in their army and raised considerable debate among the Indian intelligentsia in the 1950's since the topography of the Indian North-East (sharing borders with Nepal and China) was already considered to be of geo-strategic significance. For a detailed study of the Gurkhas and their contested relationship with the Indian state please see Gurkhas at War: in their Own Words: the Gurkha Experience, 1939 to the Present by John P. Cross (London: Greenhill Books, 2002). 
entered into cross-border alliances with neighboring states to maintain administrative pressure in the area (Lacina 999). The continuing resistance movements in the region pose a significant challenge to the hegemonic consolidation of majoritarian nationalism and neoliberal principles of progress.

In recent years there has been a resurgence of interest in writing from the periphery -coterminous to questions of the vernacular, world literatures, and the politics of translation (Apter 2014). These critical conversations interrogate the political, economic and cultural channels through which literary works from specific national traditions enter the world republic of letters (Casanova 2004). The prominence of Anglophone writing from India in the international literary sphere has meant, on one hand, its isolation from the vernacular literary tradition and, on the other, the restriction of its influence within a relatively small social group of English educated readers and critics. The educational and class privilege of its preeminent practitioners have, in turn, provoked some scholars to question the viability of the Anglophone novel as a medium of representing grassroots level concerns (Ahmad 1991; Gopal 2009). The representation of the Gurkha insurgency in The Inheritance testifies to the possibility, I want to suggest in this chapter, of re-situating the obliterated or less acknowledged struggles of specific marginal communities within the frame of Anglophone fiction.

Emerging with its own distinct national character, Anglophone literature from India predates the concurrent rise of both postcolonial and globalization theory in the 80's. Kiran Desai consciously adapts and re-orients the formal and thematic concerns of Anglophone fiction, most notably, its persistent shaping of the postcolonial nation. Instead of reactively mirroring the literary marketplace, the author -- self-consciously, it seems -- positions her narrative to emphasize an earlier intellectual and artistic genealogy. Desai's exploration of the inter- 
generational tensions within the postcolonial family, for example, replicates the familial setting used by pioneering authors of Anglophone writing such as Shashi Deshpande, Kamala Markandaya and Anita Desai (Kiran's mother). Even as the main narrative of The Inheritancethe underdog's dream of making it big - captures a classic trope of globalization-era fiction, it simultaneously harks back to pre-globalization literary texts. Such intellectual and aesthetic crosscurrents in The Inheritance form a narrative, as I discuss later, that comments on its own contradictions.

The family form emerges as the dominant allegorical trope in pre-globalization Indian Anglophone writing, serving as a gendered space where the contradictions of the decolonization process are most acutely visible. With its etymological root in the idea of the "natio" or "natal," the nation is intimately connected to the native community or family. In The Inheritance, the displacement caused by the advent of neoliberal globalization results in the rupture of the bourgeois family structure. If the broken or dysfunctional family epitomizes the paradoxes of capitalist development, however, it also serves as a site of identification and familiarity. Desai reclaims the family form, in its symbolic significance as a space of belonging, in The Inheritance. Social mobility, whether for individual self-cultivation ${ }^{6}$ or economic empowerment, must come at the cost of a break with the 'natio' and often with profoundly alienating effects.

\footnotetext{
${ }^{6}$ The idea of individual self-fashioning, juxtaposed against that of national self-fashioning is often nuanced in postcolonial women's writing from India. Tanika Sarkar offers a rigorous criticism of the process of an upper-caste, Hindu, male self-fashioning as envisioned in much of $19^{\text {th }}$ and $20^{\text {th }}$ century Bengali literature. Such a process, considered an important part of the making of the national citizen-subject, focuses almost entirely on the male hero in literary works. A related study on the relationship between the family, gender and nationalism is also provided in K. Jayawardena's Feminism and Nationalism in the Third World (London: Zed Press, 1986). Jayawardena explores the tension between postcolonial Feminism and Nationalism through a detailed study of women's political struggles across Asia and the Middle East.
} 
The Inheritance deploys a disjointed narrative structure ${ }^{7}$, sustained through the use of pastiche and flashback storytelling. At the same time, the sequence of events invoked throughout the story chart a teleological movement that spans the colonial era, the post-Independence years and the contemporary moment of neoliberal globalization. The disjointed narrative oscillating between temporal and spatial frames mimics the vast movements of populations and labor within nations of the former Third World as well as to metropolitan centers across the globe. At a formal level therefore it reflects the intersection of history and fiction in the periphery. Such displacement is contextualized however, as the ancillary effect of colonial history, the challenges of decolonization and postcolonial nation-formation. The spatio-temporal unevenness of the narrative situates The Inheritance as a novel of globalization, implicating it at the same time in the particular crosscurrents of Indian national history.

The spatio-temporal structure of Desai's The Inheritance of Loss reflects (and complicates) the trajectory of post-Independence nation building in India. The oblique reference to Indo-USSR relations through Sai's parents recovers the relegated history of Non-alignment: the Bandung conference of 1954 and India's preeminent role in advocating a politics of democratic international participation for marginalized nations (Abraham 2008). The novel's invocation of this history of national "empowerment" is, however, effectively counterpoised against the paradoxes of the contemporary moment. Represented by the Gurkha insurgency on

${ }^{7}$ The spatio-temporal fragmentation of The Inheritance of Loss is a common trope in globalization fiction. It is visible in the works of noted women authors of globalization such as Jhumpa Lahiri, Farida Karodia, Shani Mootoo and Monica Ali. Karodia's Daughters of the Twilight (1986) critiques the education system for colored peoples under Apartheid in South Africa, her other novel A Shattering of Silence (1993) describes Mozambique under Portuguese colonization. Pulitzer-prize winner Jhumpa Lahiri's The Namesake (2003) oscillates between India and the United States; similarly Monica Ali's Brick Lane (2003) depicts the life of the Bangladeshi community in London. Traversing multiple geo-political locations, like Desai's The Inheritance, these novels explore diverse modes of peripheral existence both in the Third World and the fringes of the First World. 
one hand and Biju's clandestine tryst with New York on the other, the novel emphasizes the fault lines of postcolonial progress and contemporary Indian national self-fashioning. The struggle of the aspiring working-class offers a critique of neoliberal globalization that is historically as well as ideologically situated in the novel.

India is often considered -- unfairly according to some critics -- as a representative example of the postcolonial world. Even though the word 'postcolonial' is loosely associated with the so-called Third World, India, as Arif Dirlik points out, has been its most prolific and prominent model. Originating in the 1980's, the term postcolonial is deployed discursively to not only categorize intellectual concerns of the Third World but also reflect a "global" condition (Dirlik 330). The Inheritance uncovers what postcolonial theory has systematically sidelined, namely, the appeal of both modernization and nationalism among populations in the Third World ( Dirlik 337). The stylized constellation of three distinct phases of Indian history in The Inheritance of Loss resituates the nation as the sanctioned unit of political organization while at the same time reclaiming a 'postcolonial' consciousness as a viable critique of metropolitan discourse.

Scholars such as Graham Huggan and Sarah Brouillette have uncovered a structured tendency in contemporary theoretical discourse to commoditize the "playful" and the "exotic" at the expense of more rigorously combative, contrarian elements in postcolonial literature. Such an appropriation relegates the deeply uneven interaction between the local and the global that surfaces in this literature as a "crisis" of representation. Indeed contemporary literary works such as Desai's The Inheritance foreground the difficulty of disengaging from inherited narratives of national belonging or (un) belonging. The radical break with the past that is so crucial to formulations of globalization theory is therefore never quite achieved in real terms. In The 
Inheritance such crisis expresses itself formally through a many-layered story that replicates the uneven spatio-temporal process of globalization.

Even though the word globalization occurs very few times in The Inheritance of Loss, the novel does invoke situations that reinforce the very inscrutability and abstractness of the term. In the absence of a single, comprehensive definition, it could be said that globalization manifests itself in the narrative in the form of commodities that connect the center and periphery. Sai is an avid reader of the National Geographic magazine, even Lola and Noni, the middle-aged sisters, use "imported" grocery items on a regular basis. Their niece, a fluent speaker of the English language, works as a correspondent for the BBC. These are references to commodities - both material (money, products) and abstract (information). Biju and his fellow illegal immigrants in New York embody a third form of commodity - human labor. Labor is also in circulation across the globe, sometimes by coercion, sometimes freely under the illusion of upward mobility.

Commenting on contemporary literary production from India in the age of neoliberal globalization, eminent contemporary author Rana Dasgupta ${ }^{8}$ asks with stark pragmatism, whether one can apply the term "postcolonial" to India in the globalization era. The new Indian novel, writes Dasgupta, "is concerned not to enquire after the essence of a formerly colonized place, but to ask sharper, more troubled, eminently metropolitan questions: how do all the radically different parts of this reality fit together, who is in control of it and what does it mean?" (2010) Desai's The Inheritance of Loss in many ways grapples precisely with the same problems,

${ }^{8}$ Rana Dasgupta is a preeminent writer and essayist of British-Indian origin. His novels, like Desai's The Inheritance, deal with globalization and its myriad impact across the world. Dasgupta is the author of two critically acclaimed novels, Tokyo Cancelled (2005) and Solo (2009), and a recent non-fictional work on the effect of globalization on the Indian capital city of Delhi. He was been awarded the Commonwealth Writer's Prize and shortlisted for the Llewellyn Rhys Prize. 
but with due acknowledgement of the continuity of the parochial into the contemporary moment. As a notable critic comments Desai's is the story of "a talented daughter of an internationally acclaimed novelist ... and a cosmopolitan writer ... moving casually within the transnational league of ... 'diaspora' writing." (Meyer 167) It is perhaps for this reason that Desai's novel, despite the mixed feelings of critics at its phenomenal Booker Prize win, has been described as “intelligently postcolonial" (Moseley 295). The Inheritance of Loss, as we see in the next section, recovers struggles for self-assertion in the periphery as a mode of resistance against neoimperial, capitalist globalization.

\section{Kiran Desai's The Inheritance of Loss as Novel of Globalization}

The Inheritance of Loss balances multiple worlds and narratives in the ephemeral but beautiful setting of India's North East. It invokes the lived experience of several diverse demographic groups who are caught at a particular historical juncture between a feudal-colonial life and the elusive possibilities of a global modernity. The narrative universe it describes is thus delicately poised amidst a number of contraries - on one hand is a disintegrating class of postcolonial elites, on the other an insurgency peopled by various subordinated groups who are trying to negotiate their own space within the overarching rubric of the Indian nation-state. Parallel to this narrative is that of migrant labor, represented by Biju who is navigating a similarly unwelcoming terrain, as an illegal worker in New York. These varied strands come together in The Inheritance to reveal a world in which progress and underdevelopment are inextricably combined. The story uncovers the violent and exploitative realities that are often coopted by the narrative of globalization, democracy and progress in an uneven world. 
Set in the backdrop of Kalimpong, a hill-station at the foot of the Himalayas, The

Inheritance revolves around a small, quirky group of middle-class Indians who lead their lives in relative material comfort, among the native Lepchas, Bhutias, and Gorkhas ${ }^{9}$ who make up the servant class and live in abject poverty. Desai's description of this idyllic, "feudal" setting is replete with poignant irony, as the grand narrative of globalization is counteracted through the lived every day experience of difference between those who benefit from it and those who do not. Among the rich is the London returned, retired judge Jemubhai Patel, who lives in a gothic bungalow style house Cho Oyu, bought from a Scotsman. It is primarily around the judge's household that the narrative revolves.

Besides the judge himself, this household is comprised of Sai, the judge's orphaned granddaughter, and the cook who constantly thinks about his son Biju, who is in the United States. Mutt, the judge's pet dog, is the fourth, much beloved member of the house. In the very beginning of the novel Desai builds a certain narrative tension between the middle-class, propertied characters of the novel and the peripheral native populations; scattered incidents of petty theft, break-ins etc threaten to disrupt the complacent lives of these characters. Early in the novel Desai describes an armed robbery at Cho Oyu, which foregrounds among other things the widespread anger of the natives and the local poor against the oppressive, feudal-colonial wealthy, land-and-property owning middle-classes.

Ironically the robbers involved in the incident are described as rather unconvincing - a ragtag army of insurgents comprising mostly local boys in their teens. It was the judge's fabled

${ }^{9}$ The word Lepcha refers to original inhabitants of the state of Sikkim, the Bhutia to an ethnic group of Tibetan ancestry, and Gorkha also known as 'Gurkha' to soldiers from various Nepali hill ethnicities in Northern India. The Lepchas, Bhutias and Gurkhas form part of the multiethnic local population of the Indian North East. 
collection of guns, supposedly "dated from his days in the Indian Civil Service ${ }^{10}$," that the insurgents had come to seize by force. In spite of the threat of violence that these robbers are meant to pose, ultimately they stand exposed -“The oldest of them looked under twenty, and at one yelp from Mutt, they screamed like a bunch of schoolgirls, retreated down the steps to cower behind the bushes blurred by mist...shivering there in their camouflage." (4) Rather than inspiring fear, the image invoked here is one of pity; the "schoolgirl"-like insurgents who are "cowering" and "shivering" in the cold are hardly a threatening presence. Through this brilliantly tragic-comic description, Desai is able to highlight the vulnerability of the so-called "insurgents" who form the most marginalized demographic in the North East.

Desai's depiction of the insurgents, so-called by the popular media, uncovers an alternative understanding of the history of armed struggle in the Indian North East. ${ }^{11}$ Because of the Indian government's punitive policies of forced integration, re-location, increased military violence and promotion of local autocracies, the states of the North East continue to remain politically volatile and violent. By using insurgency as a plot setting Desai not only draws the attention of a wider reading public to a little known and little acknowledged crisis (it is one of

${ }^{10}$ The Indian Civil Service reference in Desai incorporates yet another instance of colonial era elitism and corruption continuing into the present. Formerly known as the Imperial Civil Service in the $19^{\text {th }}$ century, the ICS was a small, highly selective group of civil servants, mostly British, who were assigned various administrative, civil service posts in the colonial era from 1858 to 1947. The fact that the participants of a domestic insurgency target the judge's guns from his Civil Service days (very much a remnant of colonial power) strikes a note of comic irony in the novel (Ann Ewing, "The Indian Civil Service" www.britishempire.co.uk. Accessed Dec 30" 2016.Web.)

${ }^{11}$ The North East in India comprises the seven provinces, popularly termed states, of Assam, Sikkim, Meghalaya, Arunachal Pradesh, Tripura, Manipur, Mizoram and Nagaland. Many of these provinces have been involved in a long struggle for autonomy from the Indian nation-state. Subir Bhaumik, in his book Troubled Periphery: The Crisis of India's North-East (2009), outlines the history of communal, ethnic and class tensions in the North East in India. The various smaller ethnic groups in this region have been agitating for a separate nation for a very long time on the grounds that the Indian government had systematically underdeveloped them. 
the few Anglophone novels that do so), she also dismantles the idea of postcolonial Indian progressivism and national integration. When contextualized within the violent history of military oppression and corruption in the Indian North East, the so called insurgents certainly seem to invoke at least an ideological sympathy that is consistent with their representation as vulnerable locals.

Desai, I would argue, in fact makes a strategic choice in describing the robbery at Cho Oyu towards the very beginning of the narrative. Not only does the episode foreground the escalating tension between the two groups described in the narrative, the landowning migrants and the ethnic poor, it also effectively reveals that in the periphery of the periphery, the violator and the violated, are both merely caricatures of themselves. The insurgents, for example, try to maintain their façade of machismo by imitating movie stars. The judge in turn attempts to scare them with an equally fake threat to call the police when in reality he did not have a telephone in the house. The insurgents also note that the house itself is in decay: "a few bits of rickety furniture overlaid with a termite cuneiform stood isolated in the shadows along with some cheap metal-tube folding chairs." (6) This is a tragic place to have power over, or to hunt for resources. Despite the "performative" caricature aspect of the scene, it does prefigure the very real danger of armed violence that gradually unfolds in the novel.

A brief interlude on the part of the state - when the police arrive at Cho Oyu to investigate the robbery - brings the cook's own situation into focus. After a good look at the big house conducted in complete deference to the judge who was locally respected, the police turn to the cook's little shanty. Their assumption of authority on this occasion is telling in their casual, commonsensical mishandling of the space. It is also the first time that Sai, who had accompanied the policemen, encounters the poverty of the cook's dwelling: "a few clothes hung over a string, 
a single razor blade and a sliver of cheap brown soap, a Kulu blanket that had once been hers..." (13). The policemen rummage mercilessly through the room turning it inside out on the belief that a robbery in the house must implicate the servant in some way. As the cook and Sai attempt to restore the room to its former order, Sai is overcome with the realization of the chasm between her and Panna Lal. The incident posits a provocative digression from the middle-class milieu of Anglophone fiction - re-situating the little acknowledged narrative of the underprivileged domestic help - a demographic often relegated to the margins, both socially and textually.

If the cook posits an exemplary instance of the servant class, Lola and Noni, two single, middle-aged, Bengali sisters, posit a perfect example of middle-class attitudes to the poor. Unabashedly contemptuous of the poor who surround and serve them, they contribute to the growing tensions between the locals and the settler middle classes. In a notable passage early in the narrative Noni reflects on the significance of maintaining the class divide - "It was important to draw the lines properly between classes or it harmed everyone on both sides of the great divide. Servants got all sorts of ideas and then they realized the world wasn't going to give them and their children what it gave to others, they got angry and resentful." (67) During her close interactions with Sai, Noni had often expressed concern that Sai was being brought up by the uncivilized cook. For Lola and Noni modernity is a privilege that must inevitably fall in the share of those who have been meticulously groomed for it.

The representation of Lola and Noni in The Inheritance is closely aligned with the representation of single, professional women in postcolonial literature. A comparable example from Anita Desai would be Illa Das, the unmarried female social activist and teacher in Desai's Fire on the Mountain (1977). Defined predominantly by her sycophantic attachment to the protagonist Nanda Kaul, a rich widow and owner of a big house, Illa Das inspires no sympathy. 
Yet her violent end in rape and murder brings the narrative to an entirely unexpected and shocking closure. Lola and Noni demonstrate a similar adherence to an essentially "feudal" system which provides them very little social protection when, for example, they turn to the local bureaucrats to complain about the insurgents. While on one hand their very articulations of a misguided faith in the system uncover a trenchant critique of dominant middle-class attitudes, at the same time it highlights the powerlessness of single, unattached women in a society where they must always become soft targets.

Lola and Noni's "feudal" social imaginary is complemented by the cook Panna Lal who plays the role of the servant to perfection. He is devoted to the judge and is an enthusiastic spokesperson of his glorious past - both professional and personal. This is of course a means to heighten his own self-importance in the eyes of the locals, as the chosen employee of such a great man: "A great statesman, he told them, a wealthy landowner who gave his family property away, a freedom fighter who left a position of immense power in court as he did not wish to pass judgment on his fellow men." (55) This history is riddled with contradictions: the judge's father ironically was a petty, corrupt bureaucrat who made money out of falsifying witnesses for court cases. Through a narrative aside, the novel emphasizes and underlines the paradox that he was "proud of his ability to influence and corrupt the path of justice...(Who would think his son, so many years later, would become a judge?)" (57). It is this "blood money," after a fashion, along with a sizeable dowry from his marriage, that enables the young Jemubhai to travel to England for his studies.

The cook's depiction of the judge's past is an idealist one, consistent with the construct of the male nationalist subject popularized, among other areas, in post-Independence Indian 
cinema. ${ }^{12}$ However it is also an act of willful distortion, carried out with complete self-awareness and to entirely selfish ends. It is eminently possible to read Panna Lal's subaltern, counterfeit patriotism as a gesture towards the dappled politics of postcolonial India, particularly the Indira Gandhi-led government's suspension of democracy during the Emergency ${ }^{13}$ which is referred to several times in the novel. It is revealed in the course of the narrative that Jemubhai himself is aware of such equivocation, and that it is a source of private shame, since he is the exact opposite of what the cook projects him to be. His shame brings to light an alternative history in the narrative: that of his miserable life in England, his misbehavior towards his wife, his great hatred for his plebian roots (born in the Gujarati peasant caste) and his preoccupation with English manners and habits.

Jemubhai's experiences in England form the basis of his alienation so that he finds himself unable to assimilate either with his family or with the community of middle-class migrants in Kalimpong. The sections describing his past life highlight the profound "otherness" which marks the judge's consciousness. His diasporic experience as a colonial native student in England resulted, predictably, in the erasure of his self -

${ }^{12}$ The theme of nationalism and the self-sacrificing, patriotic hero was common in postIndependence Indian cinema. Notable examples include Mehboob Khan's Mother India (1953), and Haqueeqat (1964) by the same director. Shaheed (1965) told the story of prominent freedom fighter Bhagat Singh. Cinema in Hindi and other indigenous languages formed and still forms an important popular media among the poorer classes to which the cook belongs. Panna Lal's "cinematic" construction of the judge's past echoes the former scene of the robbery where he "performs" the traditional role of 'the poor servant' also a common trope in Indian cinema. ${ }^{13}$ Indira Gandhi, daughter of anti-colonial icon Jawaharlal Nehru, and India's first and only female Prime Minister, unilaterally declared an Emergency $(1975$ - 1977) on the grounds of national security. This was done to counter the effects of the economic crisis of 1973 and the recently concluded war with Pakistan in 1971. Under the guise of patriotism and national security, the Emergency oversaw the brutal harassment and suppression of activists, artists and intellectuals, and the suspension of democratic and civil rights for the entire Indian population. 
He grew stranger to himself than he was to those around him, found his own skin oddcolored, his own accent peculiar. He forgot how to laugh, could barely manage to lift his lips in a smile, and if he ever did, he held his hand over his mouth... he began to wash obsessively, concerned he would be accused of smelling...to the end of his life, he would never be seen without socks and shoes and would prefer shadow to light...for he was suspicious that sunlight would reveal him, in his hideousness, all too clearly. (40)

Almost as a parodic revenge of sorts, after returning to India the judge buys Cho Oyu from a colonial official, cultivates his "English" habits and acquires a cook who is well-versed in European culinary arts.

The alienation of the colonial, peripheral subject inhabiting the unfamiliar space of the metropole extends to his private life as well, rupturing his ability to form interpersonal bonds. The effect of Jemubhai's self-abjection is most pronounced, for example, in his relationship with his newly wedded wife Nimi Patel. Dark, petite and plain looking Nimi lacks sophistication and polish, being an uneducated village belle unaccustomed to the judge's "English" ways. The contrast between them is heightened with every passing moment as Jemubhai attempts to train her, help her overcome the parochial, country manners. His self-doubt reaches a climax however as Nimi, instead of giving him her uncritical respect, makes fun of his westernized bearing; he is utterly exposed before her in his hideous duality as caricature, mimic man, an embodiment of the Third World subject's failed attempt to Europeanize.

A short but impactful episode of marital rape underscores the violent consequences of the judge's battle with identity. The incident occurs when Nimi tries to hide one of the judge's prized colonial possessions - a powder case with a puff. The white and pink concoction fascinates and humors her as she plans an elaborate trick - she would hide it from her husband and produce it at the right moment. The judge is furious as he confronts Nimi after looking for it 
all over the house. Nimi makes fun of the fact that he, a brown-skinned Indian man, would have need for a 'feminine' beauty product. To compound insult with injury she had hidden the puff an object he frequently applied on his skin - between her breasts. The judge grabs it from its resting place "pulled forth, like a ridiculous flower, or else a bursting ruined heart" (168). But for the poor woman the violation of her love and faith is more than metaphorical as Jemubhai "clamped down on her, tussled her to the floor...[and] stuffed his way ungracefully into her" (169).

The rape is not merely punishment for Nimi's transgression but an assertion of power over the powerless subject. It is in a perverse sense a mode of self-validation for the judge whose ego Nimi had effectively bruised. As the judge continues to repeat the act its crudity and hideousness overwhelms him with a desire to hurt Nimi - exact his revenge: "he would teach her the same lessons of loneliness and shame he had learned himself" (170). Such a characterization of Jemubhai is a conscious play on a familiar figure in postcolonial fiction, that of the anglicized native, a common type in the work of Salman Rushdie, V.S. Naipaul, and even J.M. Coetzee. Such a figure, according to the postcolonial theorist Homi Bhabha, is a "mimic man" (the phrase itself is from Naipaul) - the "effect of a flawed colonial mimesis, in which to be Anglicized is emphatically not to be English" (1984:128, original emphasis). The recovery of such a shameful episode presents the judge as an utterly loathsome figure. He is not a "figure of farce" who positively resists the naturalizing impulse of Empire, as Homi Bhabha theorizes. Rather, he is farcical in his assumed, and supremely misplaced, sense of superiority.

If Jemubhai's past is embedded in the depths of a colonial history, Sai is the product of another doomed transnational affair, the "orphan child of India's failing romance with the Soviets" (42). Born to parents who had witnessed and participated in India's bold transition from 
colonized periphery to emerging postcolonial nation-state aligned with the Soviet bloc, Sai is the product of a very particular history. Her parents, who had married after a whirlwind romance, represented the progressive ideals of the new nation-state. Her mother, a Hindu woman, had accepted without the consent of her family, a man brought up in a Zoroastrian orphanage. Both scientists, they felt they represented a new generation: “...both educated with an eye to the West...They felt free and brave, part of a modern nation in a modern world" (26). Significantly, the novel presents the communist Soviet Union as but an extension of the enlightened, progressive "West". But this epoch of glorious modernity, embodied as much in the heady IndoUSSR romance as by the inter-religious marriage of Sai's parents, was already coming to an end when Sai's father, who had been chosen from the Indian Air Force to be a part Russia's Intercosmos Program, dies in a road accident along with his wife.

The sudden deaths of Sai's parents, and the subsequent transference of her guardianship to Jemubhai, are, arguably, indicative of the historical paradoxes and tribulations of the postcolonial nation-state. If her parents' deaths mark the collapse of the progressive ideals of independent India, Sai's coming to stay with Jemubhai signify a regressive return to a national past, trapped in the moral degeneration and humiliation of the colonial era. Such a regression is not simply a plot component. It draws upon and riffs off the historical failures of the postcolonial state to achieve its proclaimed goals of democracy, sovereignty and equality. Further, it anticipates the Gurkha insurgency of the periphery that follows later in the novel. Counterpoised against the doomed insurgency story is the allure of globalization, indicated by the underclass worker Biju making it to the United States of America. This overlapping of multiple and contradictory histories and locations constitutes the unique space-time of The Inheritance - a testimony to the periphery's combined and uneven development. 
Orphaned, Sai is forced to leave her boarding school and move in with Jemubhai, her maternal grandfather and only known relative. After she arrives at Cho Oyu, however, it is Panna Lal the cook, rather than the judge, who becomes her guardian and caregiver. A rather comical episode during Sai's arrival at Cho Oyu marks the beginning of her friendship with the cook. Panna Lal completely misunderstands her background and history: "Have you come from England? The cook asked Sai ... She shook her head ... America? .... No, she said...No? No? His disappointment was severe" (25). On being told that she was an orphan whose parents had died in Russia, Panna Lal simply dismisses her as a child prone to fabricating stories: "He looked at her suspiciously ... Children often made up stories or were told them so as to mask a terrible truth." (25) The irony of the situation of course is that Sai's story is in fact true. However, it is the cook's belief in the possible existence of another, more "terrible truth" that incites both pity and affection in his heart; for him, the girl clearly seemed "special" (28).

The cook's disappointment that Sai had come neither from England nor America, the only two Western nations he knows of, reveals that the categories of the First and Third World have concrete implications for him, an uneducated servant. He already felt a loss of status in that his father, the previous cook, had served an Englishman whereas he was serving the judge, an Indian. The cook "awaited modernity and knew that if you invested in it, it would inform you that you were worth something in this world." (72) This awaiting is rewarded when the news comes that his son Biju had "a new job in USA" (85). Panna Lal shares this news with other people in the community, belonging to a much higher economic bracket, whose children were also there. For the cook, both the judge and Sai's parents represented individuals who had failed to take advantage of the many possibilities and opportunities offered by the West. By contrast, he hoped and sincerely believed that, "One day [Biju] his son would accomplish all that Sai's 
parents had failed to do, all the judge had failed to do" (85). Biju's travel to America had opened Panna Lal's eyes to the unending possibilities of globalization. In the process, England is dethroned, and "America" is crowned, Panna Lal feels, as the "Best country in the world. All these people who went to England are now feeling sorry...” (85).

Such unfaltering faith in a capitalist globalized modernity distinguishes the cook from the other characters in the novel. It also aligns him with a second familiar prototype in Indian Anglophone novels on globalization - the underclass worker who wants to make it big. The ragsto-riches narrative forms the base line, for example, in Vikas Swarup's $Q \& A$ (2005), and Aravind Adiga's The White Tiger (2008), both of which received wide critical acclaim much like Desai's The Inheritance. There are other significant resonances between these narratives; Biju, like the protagonist of Swarup's novel, is a waiter, and the cook, like the protagonist of The White Tiger, wants to get the better of his master. There is a major difference between these narratives though: Biju, on whom Panna Lal has pinned his hopes, does not become a financial success like Ram Mohammad Thomas, the waiter in $Q \& A$, or Balram Halwai, murderer and entrepreneur in The White Tiger. Biju and Panna Lal's story, deeply intertwined as it is with the Gurkha insurgency, highlights the paradox of globalization - an era when even the peripheral, ex-Third World subject can become a success with the right moves.

The cook's hope about the rewards of capitalist modernity becomes his tragic error in The Inheritance. The reader, unlike the cook, is made aware of Biju's reality early on in the novel; it is anything but a "fine-suited-and-booted-success" (80). In fact Biju (like his father) had fabricated his own version of the "American Dream," taking care not to reveal to his family the risks he incurred to survive as an illegal immigrant in the USA. He lived in abject poverty, comparable to that of the indigent lepchas and bhutias of his home town Kalimpong, and the 
version that he filtered to his father was in fact, another "fiction of globalization" (O'Brien \& Szeman 2001). If the cook took pride in his son being in the USA, Biju suffered constant homesickness: "The green card ... without it he couldn't leave ... this was the absurdity ... he thirsted for it - to be able to buy a ticket with the air of someone who could return if he wished" (99). Biju's situation, waiting for legal permanent residency in the US, explicates the common predicament of undocumented workers, who have travelled across the globe to avail of the opportunities created by globalization. It reveals how the global free market in fact takes away the freedom of the migrant worker living in the periphery within the First World.

"In New York,” writes Desai, “innocence never prevails” (79). Biju realizes this basic truth while ruminating on the difficulty of getting the elusive "green card" which hundreds like him were chasing after: "Bulgarians, Irish, Malagasys - on and on the list went, but no, no Indians. There were just too many jostling to get out, to pull everyone else down, to climb on one another's backs and run" (81). It is because of this overwhelming competition that Biju has to settle for one exploitative job after another, falling prey to a dehumanizing cycle of being overworked and sleeping on the ground with the city's homeless. For people like Biju, the dreams of globalization lay on the other side of the elusive immigration hotline, where he is asked to verify "his status" when in the world of immigrant laborers there was none - "On top, rich, colonial, and down below, poor native. Colombian, Tunisian, Ecuadorian, Gambian...there was a whole world in the basement kitchens of New York" (21).

In drawing attention to such conditions of immigrant life in the urban underbelly of the US, The Inheritance departs, significantly, from the Indian-American diasporic novels of Jhumpa Lahiri, or the "immigrant novels" of Bharati Mukherjee, that primarily describe the experiences of a professional, highly educated, Indian middle class. As the son of a domestic help who has 
stepped into this world entirely by chance, Biju is neither a conventional Bildungsroman hero nor the modern, cosmopolitan subject of the postcolonial novel. His narrative, as well as that of the other immigrants from the global periphery who constitute the labor force in New York restaurants, projects an analogous situation to the poor in India; those whom Arundhati Roy, in another context, describes as the "shadow people" (Roy 2009). Like the urban poor in India whom Roy refers to, Biju and his fellow immigrants inhabit the underbelly of the metropole, always managing to fall through the cracks of the system. Highlighting the many fault lines of contemporary democracy as much as the promises of global capitalist advancement, Biju's migration story forms a crucial counterpoint to that of the judge and Sai's parents. The intermittent sections of the novel dedicated to Biju re-orient the fictional world of The Inheritance to a global reality, where the contradictions of the past are revisited through the circulation of human labor in the age of globalization.

This symbolic weaving together of three generations, and of the narratives emerging from the historical transformations in which they each play a part, signals above anything else, the continuity of colonial conditions that Desai hints at in the title itself as "the inheritance of loss" a title that symbolically correlates the novel to the family drama, where questions of "inheritance" also indicate a movement forward from one generation to the next and the symbolic passing down of the family fortune. Typically this encodes within the domestic genealogy of family drama, the conditions of its endurance. In The Inheritance of Loss the notion of "inheritance" itself is complicated by the metaphorical passing down of colonial modes of oppression, in a process that Arif Dirlik has aptly described as "the replications in societies internally of inequalities and discrepancies once associated with colonial differences" (1994: 346, my emphasis). This complex correlation between continuity in the family and continuity in 
the nation, of oppression and marginalization familiar to the colonial order, underpins the political thrust of the novel as a narrative of uneven development.

The only other character whose condition is somewhat comparable to Biju's is Gyan, Sai's mathematics tutor with whom she becomes romantically involved. As an educated young man hailing from a different kind of periphery Gyan too dreams of economic mobility. His role in the novel is an especially important one, since he exemplifies the (largely disavowed) problem of structural asymmetries in India's North East. Gyan and Sai's relationship unfurls in an already tension-filled and volatile background of Gurkha uprising against the Indian state, only to turn into a foredoomed chemistry of opposing ideas. Even during their courtship, the difference in their class background surfaces again and again. If Gyan is embarrassed by his lack of table manners when they eat at a restaurant, Sai hesitates in talking about her scientist father thinking that it would make Gyan feel inferior.

Episodes such as these anticipate the eventual fall out between the lovers, when Sai, feeling ignored by Gyan, decides to visit him at his house. This is an important episode that creates the final rift between them, pushing Gyan further towards the insurgents and Sai away from him. Sai discovers Gyan's house as a last straw in their relationship: unlike her own, it is a testament to his vastly different social location. Gyan's house is one among many more of its kind, "common to those who had struggled to the far edge of the middle class". It was something "truly dismal...modernity proffered in its meanest form, brand-new one day, in ruin the next" (256). Seeing the house becomes a reality check for Sai, reinforcing the disparity between her image of Gyan and his family's expectations from him: "a boy, combed, educated, their best bet in the big world ... Sisters' marriages, younger brother's studies, grandmother's teeth - all on hold, silenced, until he left, strove, sent something back." It is a moment of revelation for Sai 
who immediately feels "shame" for Gyan and "distaste" for herself, wondering how she had been "linked to this enterprise, without her knowledge or consent" (256).

Sai remains an intriguing, and in what seems to me to be of utmost significance in interpreting the novel, a supposedly superficial character throughout The Inheritance. The reader is not expected to identify with Sai; she seems to have very little interiority - the few passages that explore her consciousness reveal it to be turned inward, private and self-engrossed as an individual. One of the plausible reasons for this, of course, is the fact that at the present moment of the narrative, she is merely a teenager of sixteen, still exploring her own sexuality and her own individuality. Yet the narrative offers her very little opportunity to grow, reinforcing the sense of entrapment that she tries to overcome by immersing herself in the National Geographic magazine and in the cook's stories. Even her middle-aged female tutors, Lola and Noni, are more concerned about keeping her cushioned from the working class characters, who they perceive as a threat rather than shaping her mind. With no emotional attachment to her cold, unfeeling grandfather as well, Sai feels the need to chart her own path: "She'd have to propel herself into the future by whatever means possible or she'd be trapped forever in a place whose time had already passed." (74) The irony is that Sai can only cultivate her individuality by isolating herself from the tumultuous material realities of her world. But that is a contradiction in terms. Such individuality remains fragmented, ill at ease with itself, and unrealized to the very end, precisely because Sai's sheltered life does not allow her to grow and mature as an individual. The nonconsummated, non-relation between a barely socialized, female, teenaged "individual" and a conflict-ridden, class-stratified society whose "place" and "time" are out-of-joint, "already passed," points to the disjunctive experience of modernity in the unevenly developed periphery. 
Sai's encounter with the reality of Gyan's economic background is a crucial moment in the narrative of combined and uneven development. Rather than opening her eyes to the general poverty all around her, it makes Sai even more self-conscious, even more acutely aware of her difference from Gyan. Her gaze of condescension, turned upon the lower middle-class, shabby household, reflects back to her like a mirror; she experiences an overwhelming feeling of "distaste" at having allowed herself to be attracted to someone belonging to it. The scene illuminates to the reader not only the limitations of Sai's unformed perspective but also the narrowness of it. That fact that she is shocked at the possibility of being linked to Gyan's life, reveals her own sense of separation from her surroundings, where houses such as Gyan's were a commonality rather than an exception. It is only after she is rejected by Gyan -- the latter, catching a glimpse of her disgust, turns her away angrily -- that Sai realizes her limitations. This rejection and realization are necessary in preparing Sai for her future, though that future is significantly outside the scope of the novel, leaving Kalimpong in an attempt to chart her own destiny.

Gyan's predicament, as Sai realizes it to be, is the same as Biju's - the pressure to escape life in the periphery. The fact that Biju, the uneducated, underclass worker had managed to leave, whereas Gyan, a student of accounting, had not been able to land a proper job even in India, underscores the uneven impact of globalization. In an important study on youth cultures, Race, Place and Globalization, cultural geographer Anoop Nayak notes how globalizing processes have exacerbated insecurity particularly among the youth living in the extreme peripheries of the business centers, where multinational corporations tend to be based. In such peripheries, globalization not only strips away "a traditional manufacturing core," and creates "long term unemployment, part-time work, unskilled jobs, fixed-term contracts etc.”: it also engenders a loss 
of belonging to a place, an experience of victimhood that is spatialized (Nayak 2003: 3-4). Gyan represents this demographic of unaccommodated youth, who subsequently gets involved with the only cause promising any social change - the violent Gurkha insurgency affirming a right to "place".

Gyan's initiation into the movement occurs not through rising political consciousness -indeed, entities such as ideological commitment are but impossible in the disenchanted world the novel inhabits, but through the wave of enthusiasm passing through his community at the possibility of breaking routine. In a brilliant passage, Desai describes the contagious effects of the familiar paraphernalia of an uprising against the State. Specifically, these are the sights and sounds of an imaginary community: processions of people, including some of Gyan's friends, slogans such as "Victory to the Gorkha Liberation Army" resounding in the air, and the procession "melt[ing] into a single being" (156). Watching the activists make their way through the market, Gyan has a feeling "of history being wrought, its wheels churning under him ... Gyan could not help but look on the scene already from the angle of nostalgia, the position of a revolutionary" (157). This is a critical opportunity for a character like Gyan, who has been willfully cast aside by the government, to become a part of a new history, one where his existence might acquire meaning and purpose. Yet, what makes Gyan a "revolutionary" is not his willingness to participate in the movement. The complex nostalgia that he brings to this event is not a return to any idealized past, but a willingness to step out, completely and perhaps impossibly, from the present, even its seemingly more promising aspects.

The invocation of the Gurkha insurgency in The Inheritance is a reference both to actual, historical events taking place in North-East India as well as allegorical representation of the Emergency period that preceded it. The Emergency declared by Prime Minister Nehru's 
daughter and successor Indira Gandhi witnessed a period of massive administrative restructuring along with the temporary suspension of civil rights and liberties in which the course of normalcy is disrupted. Rather than delve into the historical details of the Gurkha insurgency which is a singular event among many instances of political upheaval in the country, Desai focuses on its repercussions on the lives of ordinary people. Such a thematic choice reflects an ideological concern about totalitarianism and the value of human liberty that aligns Desai with writers such as Salman Rushdie, Nayantara Sahgal, Manohar Malgonkar, Rohinton Mistry and O.V.Vijayan (Mathur 15). In Desai as in the works of these writers it is the ideological implications of political 'emergency' rather than the specific events associated with it that becomes important.

The breakout of insurgency is not declared at any one specific juncture in the novel. Instead, Desai gradually builds up an atmosphere of tension between the middle classes and the poor that is rooted in the visible economic differences prevailing in the region: "The wealth that seemed to protect them like a blanket was the very thing that left them exposed. They amid extreme poverty were baldly richer, and the statistics of difference were being broadcast over loudspeakers, written loudly across the walls. The anger had solidified into slogans and guns" (242). Before long, squatters had begun to encroach on the properties of the landed gentry, and basic facilities such as gas and electricity were getting cut off. Members of the Gurkha National Liberation Front, or GNLF, were going from house to house surveying private property, selling calendars and video cassettes and even on occasion camping for the night where it was convenient for them, all the while maintaining an impenetrable façade of "exquisite politeness" (240).

Lola and Noni's experience of the insurgency is grounded in a battle to maintain the comforts of their existence. As squatters take over their garden they struggle to hold on to their 
supply of minor luxuries - Druk's marmalade, whiskey, cheese and Sunny Fresh. Ironically their only reference for 'revolution' was purely literary: "Noni had picked a sad account of police brutality during the Naxalite movement by Mahashveta [sic] Devi, translated by Spivak..." (218). They find themselves completely at a loss therefore, when the GNLF boys come to their door demanding to spend their nights at their home. They barricade themselves into their bedroom wondering if their Nepali doorman Budhoo was hand in glove with the insurgents. The GNLF also take over the Gymkhana Club the favorite hang out of the middle-class: "Men with guns rested in the ladies' powder room, enjoyed the spacious plumbing...dawdled before the long mirror, because like most of the town's residents, they rarely had the opportunity to see themselves top to bottom" (211).

As the violence escalates in the hills, the police are deployed in heavy numbers to hunt down the GNLF boys. Very soon the movement had moved beyond a political uprising to a desire to settle personal grudges: "This was the time to make anyone you didn't like disappear, to avenge ancient family vendettas" (295). This is indeed a suggestive reference on the author's part. The insurgency does not degenerate into family vendetta, but rather as the novel seems to suggest, expands into one. The novel's reconfiguration of insurgency in terms of an ancient "family feud" recalls the British colonial-era introduction of territorial administration in the North-East, that sought to assimilate a diverse, multi-ethnic population under the "democratic" banner of the benign, paternalistic state (Shimray 2004). As an idea, the insurgency resists the hegemonic notion of a putative family of peoples, in reality coerced into subordination to one single political unit; it is thus also a grim reference to the subsequent postcolonial classification of certain sections of the indigenous Gurkha population as the Indian nation's "minorities," who must forever occupy a marginal space metaphorically and politically. The graphic violence 
described in the novel, along with its teleological scope, traces the single, complex trajectory of the Indian nation formation as a violent, genocidal process based on the patriarchal ideology of the family.

The various plot components in The Inheritance - the insurgency, Biju' life in New York, and that of Sai, get interlinked at the end when the former decides to return home and the latter to leave. Biju had wanted to drive a taxi in Kalimpong. He had been saving for it and had hoped for a cinematic reconciliation with his father, the cook Panna Lal. When Biju arrives in Kalimpong and has to take a ride with the GNLF boys, he does not anticipate the level of violence and criminality already unleashed over the hill station. The GNLF boys take away his meager luggage, his money, including all his savings, and even his clothes. Biju arrives at the gate of Cho Oyu "without his baggage, without his savings, worst of all, without his pride. Back from America with far less than he'd ever had.” (327) When Biju finally meets his father, it is a moment of profound sadness and happiness, a meeting when all hopes as well as delusions of modernity's promises have been stripped away. Sai watches from the balcony the "two figures leaping at each other as the gate swung open" (324).

If Biju's story finds a certain tragic finality, Gyan's is left ambiguous with a promise that he may or may not fulfill - that of coming back to reclaim Sai. On the other hand, Sai, who is oblivious of his resolve, decides to transform herself at the end of the novel into an active, assertive subject who has finally acquired the necessary clarity of vision. If the raw, unrestrained violence of the insurgency reveals the bestiality of human nature, it also strips away her vanity. When Sai realizes that she is implicated in the genocide and violence as a privileged subject, as much as those perpetrating them, the reasons for Gyan's rejection of her become clear: "Shame on myself ... she said ... Who was she ... she with her self-importance, her demand for 
happiness, yelling it at fate ... screaming for her joy to be brought forth?” (322). She realizes that her tears and her emotions had been "for herself" (322). Stripped of subjective illusion, Sai begins to understand that her narrative was deeply interlinked with those around her: "Never again could she think there was but one narrative and that this narrative belonged only to herself $\ldots "(322)$.

By conceding the adolescent female protagonist a chance to forge her own narrative, Desai responds to a common problem highlighted by postcolonial feminism, that of the marginal status of the daughter figure vis-à-vis the nationalist son. Elaborating on this issue, the scholar Elleke Boehmer writes that, "young women, the daughters of the nation, have generally not been in a position to shape the nation by means of their own self-generated narratives. Even if they escape the symbolic burdens of the national mother, they traditionally remain the objects or recipients of national definitions, not their originators" (108). The Inheritance is able to problematize such "national definitions" by reconfiguring the constructs of the nation and its periphery. In the figure of Sai, Desai complicates and moves away from women's fiction that exclusively encompasses the "private," to make her heroine confront the larger national problems of social injustice and inequality. Sai's failed relationship with Gyan and her first hand experience of the violence unfolding around her, testify that both love and politics are imbricated within the structures of unevenness.

As the only character who arrives, albeit at the end of the novel, to a perception of the totality of the fictional universe Sai claims her position as the protagonist of The Inheritance. Reflecting on the lives of those who had attempted to reach beyond the conditions of their existence, this time not making exceptions due to class status, Sai decides to take charge of her destiny: "She thought of her father and the space program ... of the judge's journey, of the 
cook's journey, of Biju's. Of the globe twirling on its axis. She felt a glimmer of strength. Of resolve. She must leave." (323) It is the one time in the novel when Sai recognizes that her own individuality, rather than being a private affair, is tied up to those who have come before her. Perhaps not surprisingly, such empowerment comes at a cost - the rejection of home that had "nurtured" and "sheltered" her for so long. There is in addition, a strategic spin on the comingof-age story, a twist. Sai's decision seemingly affirms her faith in the promises of global modernity. Yet ironically, she derives strength and resolve from the examples of the judge, and Biju, who both exemplify, if anything, the failure of such promise. Perhaps, the novel suggests that a movement forward is necessary for the forging of her own personality, but also that it is already doomed to fail.

\section{Conclusion}

What emerges from Desai's narrative is ultimately a provocative inquiry into the very structure of mobility and access whereby certain characters succeed and others do not. The juxtaposition between the two groups is consciously highlighted in the narrative in the form of the volatile meeting points at which their trajectories intersect. Lola and Noni's encounter with the GNLF boys, Biju's travel to India and Sai's exposure to Gyan's family are noteworthy examples of particularly crucial junctures in the story. Biju's experience at the airport, for example, offers a particularly compelling critique of the uneven movement of people across geographical spaces. While the Third World underclass travelling cheaply could be seen "squatting on the floors in big bacterial clumps" the European and North American passengers “came and went, making those brisk no-nonsense flights with extra leg-room and private T.V ... Silk and cashmere, bleached teeth, Prozac, laptops, and a sandwich for their lunch named The Milano" (285). It is a similar sight in India when Biju lands, finally. Successful Indians living, 
working abroad appeared "complacent and civilized": the others, fighting over lost luggage (299).

The episode described in stunning detail brings together myriad characters. The narrative follows Biju's perspective as each character is provided with a possible "back story" commensurate with their appearance and conduct. However, the pathos of Biju's particular position - migrant, poor, illegal - heightens the irony of the normative non-space of the airport. Indeed it is a site that heightens the incongruity of globalization - opening up unending possibilities for those who have money, access, and "polish" and making those did not seem even more out of place. The presence of the Third World immigrant at the airport seems to be an aberration rather than a normal fact of life. It is only when he steps out into the open Calcutta air that Biju has his first feeling of being human: "Sweet drabness of home - he felt everything shifting and clicking into place around him, felt himself slowly shrink back to size, the enormous anxiety of being a foreigner ebbing - that unbearable arrogance and shame of the immigrant" (300). This is also a transition from "non-space" to a space defined by stable characteristics and lived experience. As Biju looks around him, he notices with immense comfort and relief the familiar landscape of the peripheral social world.

The airport scene is significant to the story as an interlude - just as the airport itself is a space of transit - between the main sections of the story. However it foregrounds what is arguably the political thrust of Desai's narrative. The boundaries of First and Third worlds inevitably disappear for those with the means of accessing the benefits of a "globalized" one. For those at the margins it has the alienating, de-humanizing effect of displacement, loss of roots and identity. The novel's sustained dwelling on Biju's journey - very different from, yet analogous to that of Jemubhai Patel - reinstates' precisely this alienation and sense of cosmic isolation. 
The invocation of multiple geo-cultural locales and histories constitutes the uneven space-time of The Inheritance. The judge Jemubhai Patel and Biju's trajectories aligned through the theme of the journey highlights similar, though not identical forms of alienation experienced by the Third World subject in the West. The difference in their trajectories, however, is also carefully nuanced to underscore the consolidation of class difference as the factor determining the journey of the migrant worker. Unlike Jemubhai who travels legally with the financial support of his family and for a specific vocational apprenticeship, Biju does so illegally and with no specific skill set in search of opportunities. The latter's journey exemplifies what Oana Sabo describes as the arrival of "a new type of migrant in a globalized labor market" (375). As the novel charts their journeys across different continents the readers too are invited to traverse the underbelly of the metropole uncovering the little acknowledged history of the underclass worker.

It is now a commonplace to assume that the dictates of the metropolitan literary market shape contemporary global literature in significant ways. With regard to literatures from the periphery, this has meant an increased interlinking of literary value and commercial consecration of "marginality, authenticity and resistance" as commodities in the "alterity industry" (Huggan 413). The production and dissemination of literary works under the cultural hegemony of globalization, however, has also changed the meaning and scope of these terms. Contemporary globalization fiction testifies, more than anything, to the fact that the Third World is no longer simply confined to itself, but ever-present (in the form of peripheral commodities and labor) across national boundaries. It has become even more important therefore to clearly identify what constitutes complicity (in literary output) with the dominant, hegemonic culture, as well as what indicates truly interrogative and contrarian, if not radical, modes of thought and expression in global literature. 
The internal diversity in thematic and formal considerations in the literature produced at the margins of the dominant culture has made it necessary to outline their relationship with globalization. In current critical discourse, this relationship is increasingly defined as change from economic backwardness to modernization and progress. Mariano Siskind postulates that, "the peripheries of the world have an intense desire for socio-political and cultural modernization (a desire represented in and by novels)": to the end that globalization becomes "both the condition of possibility and impossibility of modernity (and of novelistic difference) in the margins of the universal" (342). Such a formulation, however, falls into the danger of oversimplifying both "desire" and "modernity," and of ignoring the myriad modes of engagement found in peripheral literatures that seek to critique the very categories by which such terms are understood and applied.

Contemporary literature from the periphery, I have argued in this chapter, represents globalization not as a condition of modernity, but as a symptom of late-modern capitalist development -- one that entails economic expansion without the transformatory, rationalizing role of bourgeois culture. One of the dominant trends of contemporary globalization has been to subordinate human desire to market forces, so that both "desire" and "modernity," as much as the desire for modernity, is mediated by the logic of capital. As such, the transformatory potential of modernity as a philosophy and idea of rational self-formation, is replaced by the strictly consumerist scramble for commodity acquisition and upward mobility. In globalization fiction, the themes of migration, displacement, the family and the nation become dynamic categories that must be understood in relation to the particular interaction of global capital with specific geo-political contexts - i.e. the nation-state. The role of literature must then encompass a 
rigorous and combative engagement with neoliberal globalization so that its many fault lines may be rendered visible. 


\title{
CHAPTER FIVE
}

\section{INVOKING TROUBLED HISTORIES: ANNE ENRIGHT'S THE GATHERING AS A CELTIC TIGER NOVEL}

\begin{abstract}
While we live in a world defined by cultural and economic flows across formally entrenched national boundaries, the world continues to be divided, in stark terms, between its "developed" and "underdeveloped" sectors. It is precisely because of the starkness of this division that the discourse of globalization seems to be perpetually caught between two competing narratives, one of celebration, the other of crisis. (Gikandi 2001: 629)
\end{abstract}

This is the anatomy and mechanism of a family - a whole f----g country drowning in shame. (Enright 2007: 168)

Simon Gikandi's description of globalization as caught in the paradox of celebration and crisis is very apt for the period of economic boom in Ireland popularized under the name Celtic Tiger. ${ }^{1}$ The term came to be associated with the years beginning in the early 1990's when the Irish economy peaked after a period of economic stagnation in the 1980's. Scholars, media pundits, and historians often argue that Ireland's newfound glamour as the poster-child of

\footnotetext{
${ }^{1}$ The term Celtic Tiger is derived from a similar one used to describe the East Asian economies known as the 'Four Asian Tigers,' including Taiwan, Singapore, South Korea and Hong Kong, that underwent rapid economic development between the 70's and the 90's. In Ireland, largescale industrialization and in-flow of corporate finance gave rise to an upwardly mobile middleclass who directly benefitted from neoliberal globalization. At one point during the Celtic Tiger period, Ireland was deemed to have one of the most globalized economies in the world.
} 
globalization obfuscated the many paradoxes of a sudden and uneven development (O'Hearn 2000; Smyth 2012; O'Toole 2010). The Celtic Tiger rhetoric of development in Ireland was undercut by parallel, and less discussed stories of crisis: unregulated spending, scramble for commodities and quick money. The Gathering (2007), Anne Enright's Man Booker prizewinning novel, charts the contradictions of the Irish Celtic Tiger through the fraught relation between two siblings, Liam and Veronica.

The Gathering presents the psychological breakdown of the protagonist Veronica as she attempts to come to terms with the news of her brother Liam's suicide. Hailing from a lower middle-class family from the suburbs, Veronica is married to an affluent corporate financier. She is a stay at home mom, living comfortably in the capital city Dublin. Meanwhile Liam falls through the cracks of the system working as a hospital porter in Brighton, England, whose duties involve the removal of severed human body parts and biological waste. The contrast in the siblings' trajectories is starkly illuminated by their respective livelihoods, both of which involve "disembodied" humanity (in a manner of speaking), but one categorized as waste and the other as value, lifestyle, and money. It is Liam's death, by suicide, that compels Veronica to engage with the scandals of the past; namely, Liam's sexual abuse as a child that his family had ignored, as well as his invisibility in the present-day prosperous lives of Veronica and some of her other siblings. The forced incursion of a less-than-salubrious family history, and family member, into Veronica's perfectly ordered life symptomatically recalls the uneven space-time of contemporary Ireland. Even as the Celtic Tiger boom enabled Veronica's prosperity, the destroyed life of Liam upsets the story of her (and by extension contemporary Ireland's) integration and assimilation into the front ranks of Westernized, globalized modernity. 
While some critics have read The Gathering as a novel about un-representable trauma, I suggest in this chapter that it is something more. Veronica has to take recourse to fiction ${ }^{2}$, sometimes as made-up facts but at other times as imaginative perception to fill in the knowledge of the past. Fiction offers a way of grasping that which is conceptually unknowable. The novel offers insight into the relation between memory and history, and the tension created by social mobility on siblings and on the older, communal notion of the family. Arguably, the recuperation - through fiction and imagination -- of a traumatic family history undercuts the developmentalist, "celebratory" discourse of the Celtic Tiger, and illustrates the persistence of historical injustices into the "crisis" of the present. As a critique of the Celtic Tiger, The Gathering achieves two important functions. It re-instates the historically marginalized object, the abused child Liam through an active speaking subject, Veronica. Second, the narrative questions postcolonial nation formation through its strategic braiding of personal histories of neglect and abuse and a rapidly instituted, uneven capitalist development. It produces, in short, a counter-history.

Even as she suffers the trauma of sudden loss, Veronica tries to recover the story of Liam's sexual abuse as a child. She often struggles to recall the specific circumstances surrounding the main event, thereby complicating the accuracy of this recovered history. Veronica's oscillation between the past and the present and her struggle to bridge the chasm between the two often projects her unreliability and instability as the narrator. At the very

${ }^{2}$ The reference to fiction writing as a therapy for psychological breakdown highlights the autobiographical elements of The Gathering. Like Veronica Hegarty, the novel's protagonist, it was a nervous breakdown that propelled Enright towards writing. Enright turned to a literary career after working for six years at the Raidió Teilifís Éireann (RTE), in addition to being a regular contributor to BBC Radio 4. Some of Enright's other notable works include What Are You Like? (2000), The Pleasure of Eliza Lynch (2002), and The Green Road (2015), and three short story collections, including The Portable Virgin (1991), Taking Pictures (2008) and Yesterday's Weather (2009). 
beginning of the novel for example, Veronica admits: "I am not sure if it really did happen" (1). Yet we see that it is precisely the protagonist's role as the unreliable narrator ${ }^{3}$ that allows the novel to launch a trenchant and historically grounded critique of the Celtic Tiger phenomenon. The specific markers of Veronica's condition - her inability to remember certain aspects of her past, her failing bond with her family - are, I argue in this chapter, symptomatic of the disjunctive effects of the Celtic Tiger in Ireland.

As Enright's most acclaimed novel, The Gathering has accrued a range of scholarly responses regarding its narrative style and political concerns. Touted, somewhat sardonically, by the author herself as "the intellectual equivalent of a Hollywood weepie," the novel invokes the pathos of a sustained mourning (Lyall). For critic Liam Harte, the emotional component of the novel is intimately connected to its specific cultural milieu: as he puts it, the "subtlety and complexity" of child sexual abuse in The Gathering lies in its depiction, of "a collective as much as a personal experience [of Ireland]" (221). Hedwig Schwall, another reviewer, echoes Harte when she comments on the freshness of the novel that is "firmly situated in Ireland" but looks at it "awry". Instead of emphasizing the Irish-ness of the novel as Harte does, however, Schwall notes that The Gathering, "focuses on basic, universal questions like the ways in which memory works, and generates mediations ...” (7). Margaret Harper claims that such mediations definitively situate the novel as a trauma narrative where the formal as well as thematic tropes of trauma articulate the protagonist's role as an unreliable narrator. For Harper, Veronica the traumatized victim "must speak confusion" if she speaks at all (2011:76). While these remarks

${ }^{3}$ I am using Wayne C Booth's seminal definition of the "unreliable narrator" as a figure who does not or cannot follow the norms of the specific literary work. See Booth's extensive study of narrative modes and voices in The Rhetoric of Fiction. Chicago: University of Chicago Press, 1961. Also see Bruno Zerweck's seminal essay "Historicizing Unreliable Narration: Unreliability and Cultural Discourse in Narrative Fiction” Style 35.1 (2001): 151 - 176. 
help to illuminate the multiple aspects of the novel, I suggest that these critics pay inadequate attention to a key question that conditions Veronica's trauma - representing through a fictionalized testimonial the Celtic Tiger phenomenon and its pre-history.

Here it has to be noted that Ireland's emergence as a global "brand" significantly impacted discussions about the Irish colonial past and the putative postcolonial present. Beginning in the 1980 's, postcolonial theory emerged as the one of the dominant critical paradigms for Irish studies, as exemplified by the stalwart scholarship of Edward Said (1990), Declan Kiberd (1995), and David Lloyd (2001), among many others. ${ }^{4}$ Such interventions aligned Irish history and culture, ideologically, with other postcolonial spaces in the Global South. In doing so, postcolonial studies challenged understandings of the Celtic Tiger as offering a "radical break" with Ireland's colonial past. As noted scholar Joe Cleary (2004) argues, Ireland's history as a colonial periphery, and the continuing political instability of the North, continues to complicate the narrative of its integration into the West. Contrary to the celebratory mood of the Celtic Tiger, for materialist-postcolonial scholars Ireland's development remains entrenched in the deeply uneven and incongruous history of its colonial past.

In its gendered critique of a national self-fashioning, The Gathering resonates with such canonical postcolonial novels as the Zimbabwean Tsitsi Dangarembga's Nervous Conditions (1988). Dangarembga's novel also begins with the death of the protagonist's brother. As in Dangarembga's narrative, the negation (through death) of a normative masculine and patriarchal subjectivity in The Gathering opens up space for the female protagonist to uncover the fractures

\footnotetext{
${ }^{4}$ See Edward Said, "Yeats and Decolonization" in Nationalism, Colonialism and Literature (University of Minnesota Press, 1990), David Lloyd, "Regarding Ireland in a Post-colonial Frame" Cultural Studies 15.1(2001), and Declan Kiberd, Inventing Ireland (Harvard University Press, 1997).
} 
of her self-identity and society. Just as Nhamo's death allows the protagonist Tambu to articulate her self-fashioning in Nervous Conditions, Liam's death has an immediate and analogous function - it triggers Veronica's traumatic memories, which she has to grapple with as well as overcome. It compels the previously silenced female, Veronica, to articulate a historically marginalized narrative of child neglect and abuse. The revival of this narrative is inherently contradictory and self-reflexive, even as it serves as a site of resistance.

The cultural impact of globalization on Irish subjectivity, identity, as well as notions of gender and sexuality has been significant, if less discussed compared to the economic aspect. In her extensive study of Irish literature during the Celtic Tiger years, Susan Cahill posits the era as a critical juncture when inherited notions of Irishness are dismantled. Unforeseen social changes, facilitated by the advent of globalization, help to create new paradigms. Corporeality, Cahill observes, is one of the most important metaphors that re-emerge in Irish literature during the Celtic Tiger years. The corporeal, as metaphor, captures the relation between the past and the present. Focusing on the novels of Anne Enright, Éilís Ní Dhuibhne and Colum McCann, Cahill argues that, "the morphology of the body inflects the way that we construct our histories and memories" (10).

In The Gathering we see the body serving as a metaphor for the psychopathology of uneven development. The traumatized narrator Veronica, and her abused brother Liam, both embody a common problematic - they are individuals whose self-fashioning within a capitalist modernity has been thwarted by the single historical event of physical and sexual abuse. As Veronica observes, this memory haunts their bodies in concrete ways: "we know there is a difference between the brute body and the imagined body, that when you touch someone, something really happens" (223). Veronica's unexamined life, enriched by her Celtic Tiger-era 
prosperity, rests on the disavowal of this particular corporeal history. It is only through the unequivocal acknowledgement of the past rather than disengaging from it that the narrator can take her first confident steps towards psychological recovery.

Using a pastiche of history, memory and trauma narrative, The Gathering formalizes the dichotomy of the Celtic Tiger moment. The testimonial mode of the novel gestures towards this plurality, through "a mixture of family history, crisis diary and fantasy," that enables "the novel's exploration of history's forms, nature, and uses." (Dell'Amico 59-60) The narrative has to cut across both time and space. Such a process invariably troubles the linear plot of the story, since every detail that the protagonist offers about the present bears the imprint of the past. The testimonial mode makes for a compelling stylistic choice, precisely because it invokes the need for solidarity on the part of the reader while sustaining the aesthetic liberties of the non-linear and non-realistic narrative structure.

Psychological trauma and child abuse, the breakdown of family ties between brother and sister, wife and husband, parents and offspring, and finally, the commoditization of human labor as value or lack thereof constitute the main political commentary of Enright's novel. The Gathering uses literary form to suggest that these aspects of contemporary Irish society, disparate at first glance, are in fact interconnected aspects of an uneven modernity. In addition, Veronica's testimonial foregrounds a larger problem of literary representation: as John Beverley's well-known study notes in relation to Latin America, the testimonial ${ }^{5}$ becomes

\footnotetext{
${ }^{5}$ The "Testimonio debate," emerged around anthropologist David Stoll's infamous attack on the testimonial of Guatemalan activist Rigoberta Menchu for apparent inconsistencies (Rigoberta Menchu and the Story of all poor Guatemalans, 1999). Analyzing the grounds of this attack, John Beverley argues for a specific form of audience response to the testimonio; he holds that it is a narrative that may or may not be real, but which nevertheless produces a reality effect (2004: 2).
} 
historical, in "the relation between the temporal sequence [of the events being narrated] and the sequence of the life of the narrator or narrators, articulated in the verbal structure of the testimonial text" (3). The Gathering's representation of a traumatic event within the sequence of the narrator's life-story, I argue, fictionalizes the testimonial genre. It illustrates how the novelization of an established non-fiction genre helps to uncover the histories disavowed by dominant (and metropolitan) discourses.

If the very title of the novel - 'The Gathering' - indicates on one hand, the idea of a "family gathering" on the sad occasion of Liam's passing, in equal measure, the title summarizes the protagonist Veronica's attempts to "gather" or collect her memories, past trauma, and present commitments into a coherent narrative. The title effectively conflates the two ideas, so that the social gathering of a broken family and the psychosomatic gathering of past events may be combined in the form of a fictional testimonial. The reconstitution of the broken family, which Veronica attempts to do in the second half of the story, becomes crucial to the attainment of formal and thematic resolution in the novel.

\section{The Gathering as a Celtic Tiger Novel}

The Gathering opens with the narrator Veronica's two daughters running around on the beach as she watches over them with maternal indulgence. But the seemingly idyllic scene hides a deeper event: Veronica has suffered the recent bereavement of her twin brother, Liam, and is struggling to come to terms with the circumstances surrounding his suicide. Narrating in the first person, Veronica introduces her brother Liam quite abruptly in the narrative. She associates childhood with her own daughters, who are distracted by dead animal skeletons on the beach. These "skeletons" bring back memories of Liam's childhood and his preoccupation with death. 
The "bones" on the beach, from which all traces of life have been removed, transform into a potent symbol of memory and words. "My brother Liam loved birds and, like all boys, he loved the bones of dead animals ... I tell my daughters to step back, obviously, from the mouse skull in the woodland or the dead finch that is weathering by the garden wall." (1) Veronica's words reveal her unease with her own memories about Liam's fascination with dead animals. They remind the narrator of things past, and force her to explicitly state the subject of her narrative. As a bereaved sister, Veronica feels an urge to write about the past and to come clean with her own knowledge of the circumstances of Liam's death.

The opening, then, is both a declaration of the author's purpose and a window into the formal structure of the novel. As the narrator announces, she writes from a deep subjective need articulating a long-suppressed history which would otherwise never be known: "I would like to write down what happened at my grandmother's house ... I need to bear witness to an uncertain event, I feel it roaring inside me - this thing that may not have taken place" (1). The mention of an event that is "roaring inside" suggests, as we find out later, that the narrator is a victim of intense psychological trauma and in considerable agony over her past. The opening pages indicate too that Veronica is not sure why or how she will bear witness.

Even though Veronica declares her need to "bear witness" to the source of her trauma, her memories of the actual event are, admittedly, in a state of chaos. She confesses even before the commencement of the narrative that she does not know "the truth," or even "how to tell the truth" (2). As an unreliable narrator of an "uncertain event," Veronica invokes the power of storytelling, combining fact and fiction constructed from memory: “All I have are stories, night thoughts, the sudden convictions that uncertainty spawns. All I have are ravings, more like" (2). The phrasing indicates the narrator's suffering even as she attempts to describe her thought 
process: "raving" encodes the idea of a metaphorical madness, a disjuncture between reality and imagination. Yet the very format of the narrative, a testimonial of a traumatic event, becomes a comment on the act of narration, uncovering the psychosomatic fractures of human subjectivity at a particular critical moment.

Veronica's struggle with the process of narration is synonymous with what the noted scholar Cathy Caruth describes as a subject-in-trauma. For Caruth, trauma is always connected to the story of a wound that cries out, and which addresses us in an attempt to describe a reality or truth that is otherwise unavailable. This truth, in its delayed appearance and belated address, cannot be linked only to what is known but also to what remains unknown in our very actions and our language (2010: 3). As Caruth notes, the process of relating the truth from the realm of the unknown is crucial: as a process it enables the charting of an alternative history to the one that is already laid out in facts and statistics. By using a narrator who arguably bears the symptoms of a trauma victim, Enright uncovers a collective unknown, a familial and national history that must be read against the grain. Veronica's condition becomes symptomatic of the larger societal and historical fractures.

The novel's recuperation of past histories of neglect and sexual abuse strongly resonate with media reports of institutional sexual violence that began to circulate in the Celtic Tiger period. In main part because of the widespread selling and buying of older property during this time, the Celtic Tiger boom, unwittingly, brought about the disclosure of previously hidden scandals. Veronica's expensive house, car and lifestyle expose a trend of unregulated consumerism. At the same time, she admits that even in her repeated forays into a traumatic past she would have never recalled Liam's abuser, Lamb Nugent, had it not been for the contemporary media exposé of similar incidents: "I would have never made that shift on my own 
- if I hadn't been listening to the radio, and reading the paper, and hearing about what went on in schools and churches and people's homes" (173). Paradoxically, the Celtic Tiger moment that leads to the protagonist's affluence also opens up the space, made possible by the increased role of the media during this time, to unearth the nation's secret history of institutional abuse.

As Gerry Smyth writes, in the 1980s and 1990s a number of high profile cases of abuse came to light in the Industrial Schools as well as the notorious Magdalene Laundries, which "had been running a system of physical and psychological terror ... much of it pedophile in orientation" (134). In his important monograph on the Magdalene Laundries, James Smith (2007) identifies the family along with the church and the state as complicit in the systemic abuse of children and women. A mode of "confinement" meant for unmarried mothers and their "illegitimate" children, the Magdalene Laundries ${ }^{6}$ ostensibly "preserved the sanctity of the family as an institution". The Gathering has to be read in light of the unearthing of these contemporary scandals. Not only does the novel engage thematically with these scandals, Veronica recuperates a similar history within her own family, thereby undercutting the rhetoric of religious morality and national pride that justified the ill-treatment of women and children. By juxtaposing incompatible narratives of sexual abuse, and moral grandstanding, the novel illuminates the female narrator's alternative vision. It is one that reveals the diseased anatomy of both the family and the nation; like the deceased Liam Hegarty, both are "drowning in shame".

\footnotetext{
${ }^{6}$ The Magdalene Laundries or Magdalene asylums were institutions for women and children run by religious groups, such as Anglicans, Presbyterians, and mostly, Roman Catholics in Ireland, from the $18^{\text {th }}$ to the late $20^{\text {th }}$ Century. These were meant for "fallen women" including unmarried mothers, adulteresses, and even young women retained simply as a preemptive measure. For a study of Magdalene Laundries, see Rebecca Lea McCarthy, Origins of the Magdalene Laundries: An Analytical History (McFarland, 2010).
} 
Picking up on this complex history as discussed by scholars such Smyth, Smith and McCarthy, The Gathering foregrounds a literary-political view of the family as an institution that is unwilling, and ultimately incapable, of providing protection or shelter. Liam's natal family lives in ignorance and denial of his abuse. Veronica's own family in turn grows more and more distant from her and she rejects her husband who cannot grasp her unstable behavior. Towards the end of the novel Veronica undertakes a journey home to her natal family in order to reveal the truth about Liam to her other siblings. It is a gesture that resists its present condition of helplessness: "even though it is too late for the truth, I will tell the truth" (Enright 259). This is not just a symbolic return to the original site of trauma but also a metaphorical "sharing" of it. In doing so it looks forward, impossibly, to a better future. In the words of one commentator, The Gathering is "a parable of a nation with the choice either to face or ignore a disturbing past" (Dell'Amico 72).

The protagonist's self-consciousness as a middle-class subject underscores her overwhelming feeling of guilt and sorrow at Liam's death. Veronica is married to Tom, and they live in a posh Dublin suburb, with their two daughters, Rebecca and Emily. Veronica drives an expensive Saab 9.3. She and Tom had bought their house, "a new five-bedroom-detached ... all a bit Tudor-red-brick-with-Queen-Anne-overtones" (36) in the year 1990. Both the house and the car are rather common purchases for people like her and her husband Tom, the beneficiaries of the Celtic Tiger. The house had been carefully and tastefully styled, "in oatmeal, cream, sandstone, slate," for upper middle-class living. Veronica is unable to sleep at that house after learning of Liam's death. She drifts from room to room, cleaning, drinking, but mostly trying to get through the night. 
The fact that the material circumstances of her life have an important function in the story is indicated by the detailed manner in which Veronica describes her home, her car, and her husband's job - things she does not entirely grasp. To quote Gerry Smyth again, middle class identity comes to be defined in the Celtic Tiger period, by "cars, more cars, holidays, more cars, houses, more houses and more cars" (Smyth 132). This is of course an "identity" not available to everyone. The austere and tasteful colors of Veronica's expensive five bedroom suburban house, contrasts sharply with the hodge-podge motley of cheap wallpaper at her grandmother Ada Merriman's house in working-class Broadstone, which (as Veronica recalls) is "a pattern of bluegreen flowers, bulbous and slightly metallic" (98). At one point Veronica recalls her grandmother, Ada, crying quietly "into the sink," and afterwards wiping her nose with her forearm, "because her hands were wet" (89). These memories make her own life conspicuous in its (apparent) difference: Veronica wryly notes that, "I have a stainless-steel Miele dishwasher. And if I have any crying to do, I do it respectably, in front of the TV" (89). Subtly, however, in the absence of any qualifying comment on the reasons for her "crying," the reader is invited to make a connection between the narrator and her grandmother; their lives, despite the difference of material objects, seem similarly abject.

As a prized commodity acquired during the real-estate boom of the Celtic Tiger, Veronica's house serves as a concrete manifestation of everything that she and even more so her husband, Tom, have worked for. The house - and the family within -- symbolizes Veronica's efforts (she recalls) to arrange, decorate, and organize a wholesome family life. She selects her pelmets carefully -- the "biggest floral" for the bay window with roman blinds -- a perfectly "landscaped garden". Yet the aesthetically ordered spatial unity of the house is ruptured by time, namely, the incursion of disturbed and disembodied memories: 
Late at night, I hear voices in bursts and snatches - like a radio switched on and switched off again, in another room. Incoherent, but quite cheerful. Stories bouncing off the walls. Scraps of lives, leaking through. Whisperings in the turn of a door handle. Birds on the roof. The occasional bleeping of a child's toy. And once, my brother's voice saying, 'Now. Now.' (38)

In this key passage, the transformation of the house from a harmonious and salubrious lived space into a dark and almost gothic presence indicates the growing instability of Veronica's psyche. Its opulence notwithstanding or perhaps because of it the house becomes fundamentally alienating and terrifying, standing in for all that the protagonist has left behind.

The narrator describes her routine in detail, a strategy that emphasizes the disjuncture caused by her psychological breakdown. She admits to losing a sense of continuity, as "there are long stretches of time when I don't know what I am doing, or what I have done - nothing mostly" (38). The rooms "open into each other nicely," as she moves through them unable to sleep at night. Often in the early hours of the morning, she finds herself cleaning the walls and then drinking, "from the top of the wine bottle to the last, little drop," before going to sleep at 7 a.m., just as her husband Tom is waking up to the sound of his alarm. The news of Liam's death affects Veronica's relationship with her family, her husband and daughters, who are extremely supportive of her at first. The news of her brother's death relegates them from Veronica's consciousness, sending her into a tailspin of long-repressed memories.

The mundane routine that Veronica refers to at the beginning of the story nevertheless enables the reader to perceive a complicated sense of historical time. Veronica's insomnia and reliance on drink are symptoms of a long repressed memory. This temporal overlap between memory and the present dismantles what Susan Cahill describes as, "a rigid distinction between Ireland's 'traditional' and 'backward' past and its 'affluent' and 'contemporary' present" (7), 
that is characteristic of the Celtic Tiger cultural discourse. For Veronica, memory is the source of trauma, surely, but that trauma is reinforced by the disjuncture of memory with a strange and alienating present.

The trauma of the female protagonist determines the narrative form. The fragmentary, dissociative structure of the novel is derived directly from the surfacing of repressed memories, which reveal the present in a new perspective. The plot is based on Veronica's recollection of past events. As a result, the present moment of Veronica's suburban middle-class life becomes more and more static throughout the novel, serving increasingly as a backdrop to accentuate her past memories. It is the past that keeps changing and oscillating between multiple events and locations. Operating outside the realm of historical sequence, the narrator is able to describe not only figments from her own childhood but even deeper into the past. She conjures up the story of her grandparents and their association with Lambert Nugent - the man responsible for Liam's fate. This framing together of three generations of family history around the singular event of Liam's abuse places it at the center of the plot.

Veronica's memories take her back to the family history of the 1960s. This is a particularly significant historical juncture to situate a family chronicle in, as it corresponds to a moment of massive social transformations in Irish society. Among other scholars, Terence Brown in his study of post-Independence Irish social and cultural history describes the preeminence of economic renewal through the 60's and early 70's in Ireland. This is the period, Brown contends, when a capitalist model of accelerated development (undertaken by the Lemass government) comes to replace the ideological vision of national integration through holistic economic growth (215). The narrative present, encompassing a similar trajectory of economic 
development during the Celtic Tiger links itself to this history. It highlights the continuity of an earlier, historical wrong through the narrator's present traumatic experiences.

Veronica is eight years old at the time and her brother Liam is about nine. They are living with their grandparents Ada Merriman and Charlie Spillane. Her grandparents are friends with Lamb Nugent, who is often present at their house almost as an intimate extension of their marriage. With Charlie absent most of the time, Nugent also shares a somewhat clandestine relationship with Ada who appears to tolerate if not indulge his sexual advances. The narrator recalls that Mr. Nugent always had sweets for the children, who were left alone with him when their grandmother retreated to the kitchen under some pretext to avoid him (103).

Even though the narrator claims to have vague memories of her grandparents, she appears to be preoccupied with her grandmother Ada Merriman in particular. In the absence of the narrator's mother, Ada the grandmother is an important maternal figure in the novel. The generational distance between Ada and Veronica allows the narrator to transform her into an almost mythical, albeit pitiable, female presence. The novel represents Ada both as victim and as victimizer. Ada reluctantly concedes to a highly complex and ostensibly sexual relationship with Lamb Nugent, while at the same time it is her negligence that allows Nugent's abuse of Liam. Though there is no evidence to support her claim, Veronica secretly believes that Ada is complicit in Liam's abuse.

Veronica describes the first meeting of her grandmother Ada Merriman and the abuser Lambert Nugent. In fictionalized detail, she lays out Ada and Lamb's meeting in a hotel foyer way back in 1925 . Veronica imagines this episode because she does not have the actual story. 
The attempt at a metanarrative is a conscious effort on the part of the narrator to provide a long historical framework against which Liam's story must be understood:

... if I have to tell Liam's story, then I have to start long before he was born. And, in fact, this is the tale that I would love to write: history is such a romantic place... if it would just stay still, I think, and settle down. If it would just stop sliding around in my head. (13)

We need to note in Veronica's remarks the overlap between "history" and "romance". Perhaps it is indicative of the narrator's attempt to defer representing the actual event, the history of Liam's abuse, that she substitutes it with something that she has either heard or entirely fabricates in her own mind -- a fictional romance involving Ada and Lamb Nugent. But history itself, she seems to suggest, is romantic. The two notions of fact and romance "slide" over, overlap and rest uneasily next to one another.

Such a framing provides the necessary tools for Veronica's narrative to evolve from "romance" to the "facts" about her and Liam's childhood. This is necessary for another reason. Fiction is important for the narrator to reach an understanding of the circumstances surrounding Liam's suicide to which, unlike his childhood abuse, she had not been a witness. "There are facts about the way Liam died," which Veronica wishes she "did not know," heightening the possibility of deferring the truth through active denial. As she says later on, "All the things I have forgotten in my life, and I cannot forget these small details" (141). There are three facts about the suicide that the narrator highlights: first, that her brother committed suicide, as evident from the stones in his pocket. Second, he wore a fluorescent jacket so that, Veronica thinks, he wanted his body to be found. Third, the fact that he wore no underpants, which could be attributed to his lacking clean underwear, but more symbolically perhaps, drawing attention to 
the fact that he had once been sexually abused. Veronica weaves a story of her brother's death using these fragmentary facts.

Similarly, Veronica's recall of family history replicates the disjointed kaleidoscopic form of a family album. The narrator's abrupt style of introducing specific events is suggestive of flipping through photographs: "Here's me, at the age of three, with my ear pressed against the beige tin cliff of her washing machine ... Here's me, eating Ada's rubber bathing hat ... Here's me, definitely, pulling the bathing cap over my face" (98-99). The narrator crafts a history that is presented in the form of vignettes rather than fully developed ideas. The fragmentary structure is commensurate with the narrator's claim that the family history that she is presenting is at the same time a romance (21). It is consistent with the form of the testimonial, too, in its careful layering of fact and fiction, which in turn, serves as an important precursor to Liam's abuse - an event that the narrator bears uncertain witness to.

It is possible that Veronica invents her grandmother's life story and her supposed attraction to Lamb Nugent as part of the fictional construction of "romance". Narrating the family history as "romance" enables Veronica to fill in the gaps of the narrative with invented or imagined stories, that compensate for the lack of facts. Fiction, emerging at the meeting point of history and romance, provides an intuitive, experiential grasp of the truth, of knowledge, replacing that which can neither be grasped by rational comprehension nor by factual record. In other words it provides a truth that is otherwise unavailable. As the narrator approaches the actual event, her pattern of recall changes from impressionistic memory to concrete "facts" (141). Veronica's emphatic declaration of holding factual knowledge in the latter case is meant to dispel any doubt in the reader's mind about Liam's abuse and that it had indeed taken place. At the same time, this incident itself is described as a "strange" vision. The fragmentary images 
that flash before the narrator's eyes as she attempts to reconstruct and narrate the event construe a horrifying picture of the child Liam at the mercy of Mr. Nugent. The language is graphic and factual, and at the same time unreal and dramatized, consistent with the initial shock of witnessing an unfathomable event and with the later struggle of finding a narrative frame for it:

What struck me was the strangeness of what I saw, when I opened the door. It was as if Mr. Nugent's penis, which was sticking straight out of his flies, had grown strangely, and flowered at the tip to produce the large and unwieldy shape of a boy, that boy being my brother Liam, who, I finally saw, was not an extension of the man's member, set down mysteriously on the ground in front of him, but a shocked ... boy of nine (143).

The reciprocal gaze of horror that Liam casts on Veronica seals their fates as victim and witness. The memory affects the narrator almost immediately, viscerally, as she struggles with the process of narration: “... there is a terrible tangle of things that I have to fight through to get to it, in my head," but even then she can grasp that Liam, her nine year old brother "was terrified" $(144,146)$.

Immediately after recounting the event, the agony of recall compels the narrator to suppress her memories: "The image has too much yellow in it, there are too many long shadows thrown ... I think it may be a false memory." (144) The enormity of the situation is rendered more poignant when Lamb Nugent sees the narrator, "a small girl in a school uniform holding the knob of a door." His reaction is only one of "very ordinary irritation" (144). Memory of the event is unbearable and cannot be recounted without difficulty: "I pause as I write this, and place my own hand over my face, and lick the thick skin of my palm with a girl's tongue. I inhale. The odd comforts of the flesh. Of being me." (146) The narrator's pause suggests her need for therapeutic release. But what the passage heightens most acutely is her need for reassurance. 
Through the act of feeling her own skin, she acknowledges that she is alive, physically unharmed and back in the present.

The act of sexual abuse dehumanizes both the victim and the witness. If Liam appears to be "a large and unwieldy shape," the narrator herself is the source of "very ordinary irritation" to the abuser. The description emphasizes the power hierarchy in operation here. The denial of the victim's humanity stems from the abuser having enormous power over him and the witness, both of whom are mere children. The image of the boy as an extension of the man's sexual organ reinforces the horror of the abuse - it reduces the boy to an object of sexual desire and gratification.

The narrative reaches a climax with Veronica's witnessing of Liam's sexual abuse; it is important to note, however, that this is the revelation of a crisis that has, ostensibly, been in existence long before its "discovery" and may perhaps be continued beyond it. Elaborating on the complex politics of representing trauma, the critic Kai Erikson writes, "a chronicler of passing events may report that the episode itself lasted no more than an instant ... but the traumatized mind holds on to that moment, preventing it from slipping back into its proper chronological place in the past ... The moment becomes a season, the event becomes a condition" (185). The act of sexual exploitation described in The Gathering propels the victim, Liam, towards social marginalization. At the same time it causes irrevocable psychosomatic damage to Veronica, who must -- through the act of narration -- re-situate the traumatic event, as Erikson suggests, to its proper place in history.

The narrator recalls that Liam starts showing signs of psychological trauma almost immediately afterwards. He becomes frightened and refuses to be alone at night. Liam "was 
never still ... he sank down off the pillow or hooshed back towards the headboard, he fussed and squirmed, or he would freeze, appalled." (117) Liam came up with the most "incredible stories" in feeble attempts to explain his erratic behavior. These fabricated narratives were meant to cover up his inability to communicate the reasons for his trauma. Here once again we see the metanarrative of fact versus fiction at play; incredible stories, and even lying, become for Liam a means of articulating what is repressed and cannot be said otherwise. The emotionally charged language through which the narrator describes the symptoms of trauma in her brother invokes not only the inscrutable shock of the abused child, Liam, but also the effects of such abuse on the witness, Veronica. At the outset of the novel the narrator describes her own situation in similar terms: "This is how I live my life since Liam died. I stay up all night. I write, or I don't write. I walk the house." (36) There is a parallel here - Liam's stories are incredible, just as Veronica as the unreliable narrator often appears to be concocting stories. Because Liam died, bereft of speech, Veronica must reclaim his voice through the act of writing and truthfully articulate the facts surrounding his abuse. But given her unreliability - is she actually writing, or not, the reader is not given a definite answer.

For the Lacanian critic, Sarah Gardam, the exploration of sexual trauma in The Gathering is intimately connected to the protagonist's recognition of "identity-as-illusion" in a context of shifting reality. Veronica's "reliving of the original trauma of split-subjectivity," Gardam argues, is "brought on by the loss of her brother and [her] consequent interrogation of the excessive nature of sexuality" (2). However, this interrogation of reality incorporates not just the trauma of the split-subject. The very process of narration brings the protagonist's knowledge of private, subjective trauma into the social, public realm in which it can -- and must -- become a shared knowledge and shared experience. The novels' use of split-subjectivity is, therefore, explicitly 
political. It emphasizes the social fractures resulting from the uneven space-time of globalization as we see below.

Once the kernel of truth is laid before the reader, the uneven trajectory of the protagonist and her brother comes into play as the driving force of the novel. Liam had an eccentric youth, the narrator remembers -- his activities were surreptitious, often rebellious. As Veronica recounts his "glamour days," when Liam is an unusually "beautiful" teenager, she also considers the reckless life he led, even getting into trouble with the Gardai ${ }^{7}$ on one occasion. The basis of their relationship is an elaborate charade; they consciously or unconsciously pretend that, "it was all a complete joke" (167). Liam was attracted, Veronica recalls, to those who suffered - perhaps his own secret suffering formed the basis of a human empathy, extending to "the poor, the destitute, the lonely, the alcoholic ..." (167). Years later, the adult Veronica comes to share the same character trait: "I love the ones who suffer, and they love me" (145). The feeling of utter abjection and fear, underlining the pathos of the private suffering self resurfaces in both siblings in their empathetic attraction towards the weak and the vulnerable. It binds them together in a deep, implicit sense of shared trauma.

Veronica's grief at the loss of the brother with whom she shared an unspoken bond of empathy is heightened by guilt. As she reminisces on the nature of their youthful interactions, Veronica realizes that she may have been unkind to Liam for his personal oddities: “... not only did I laugh at my brother, but I let my brother laugh at himself, all his life". This may have been a factor, she wonders, which contributed to his alcoholism. Veronica's supposedly blissful life, in the Celtic Tiger moment, is counterpoised against this realization; it is further heightened by

${ }^{7}$ Garda Síochána is the name of Ireland's national Police force. The word "Gardai" is the plural form, meaning "the guards". 
her feeling, that Liam, “... blamed me for twenty years or more. He blamed me for my nice house, with the nice white paint on the walls, and the nice daughters in their bedrooms of nice lilac and nicer pink ... he blamed me for my golf-loving husband ... He treated me like I was selling out on something..." (168). Consistent with the generic conventions of the testimonial, this admission is an expression of internalized guilt emanating from Veronica's awareness that Liam felt let down by her. It is this acute sense of guilt that propels Veronica to interrogate her own development as she recalls Liam descent into an abyss of loneliness, despair and poverty.

Such interrogation profoundly affects Veronica's attitude about her marriage to her corporate financier husband Tom. It is through an exploration of Veronica's thoughts on this marriage that the novel offers an explicit critique of capitalist globalized modernity. Veronica refers to Tom's corporate finance job and his earnings, their chief source of income, multiple times in the novel and always with a sense of deep if resigned skepticism: "Tom, my high maintenance man is upstairs dreaming his high maintenance dreams of hurt and redemption, in the world of corporate finance, and it is all nothing to do with me.” (36). Just as Veronica feels excluded from his world, Tom too cannot understand her need to leave the house on her own. According to the narrator, “'I just don't know where you're coming from' he says. A corporate phrase from my corporate boy." (152) It is of course not clear from such references alone whether Veronica is critical of corporate finance itself or if it is something more inscrutable and abstract that divides them. What is evident, however, is that the novel balances such references carefully, not only to contextualize the novel within the larger world of global capital, but also to link the latter to questions of human subjective experience.

Veronica's perception of Tom is fictitious, in part. She resents Tom for making her give up her job. Paradoxically, it is Tom's salary that allows her to be a stay-at-home mother and wife 
and also affords her the luxury of not functioning "normally" when she has her breakdown. Tom in fact takes up more of the house chores and parenting responsibilities; he oversees the dance lessons for the kids, the sausages for dinner ready in the fridge, and so on, so that Veronica has the opportunity to mourn and recover from her trauma. The free time that Tom provides Veronica only adds to her problems. She loses not only her income and financial autonomy but also the sense of stability that her duties as a mother and wife provide. In this way, Tom's success and kindness causes Veronica's own life to be unsettled.

The deep unevenness of Irish globalized modernity is invoked more directly through Veronica's comparison of Tom's success with Liam's failure. These men offer two contrasting pictures of the Celtic Tiger. As a financier Tom is responsible for "moving money around," electronically. "Every time he does this, a tiny bit sticks to him ... Quite a lot of it, in the long run." (39) If Tom's job entailed the circulation of fictive, speculative capital, Liam's work was to transport human waste as a porter at the hospital: "He pushed beds down corridors, and put cancerous lumps into bags and carried severed limbs down to the incinerator, and he enjoyed it, he said. He liked the company." (39) Liam belongs to the demographic of marginalized, nonintegrated and under-employed working class, a reserve pool of informalized and precarious laborers that, unlike Tom, is little acknowledged during the Celtic Tiger years. It is also significant that he does his job in England, as an immigrant, thereby continuing the long and often ignored history of Irish immigrant labor in low-paying menial jobs in the English metropole. The human body parts, which Liam transports, literally represent his disconnect from an uneven, globalizing modernity. One is reminded of the drunken porter in Shakespeare's Macbeth, guarding the door to Hell. Just as the cancerous human remains are discarded, so too 
are characters such as Liam who have no role to play in Ireland's journey to success with neoliberal globalization.

Liam represents the particular demographic of the Irish male that is out-of-step with the accelerated modernization of the Celtic Tiger years. This male prototype surfaces in Patrick McCabe's oft-cited Irish novel, The Butcher Boy (1992), which depicts the protagonist, Francie's pathological degeneration into criminality in the context of 1960s' rapid industrialization. Even though there are no direct references to McCabe's earlier novel in Enright's text, the two novels share a common preoccupation -- the estranging effects of a rapid and uneven modernization on notions of masculinity. Significantly, the negative characters in both novels share the name "Nugent"; the texts, similarly, deploy the device of the "split-personality" to embody the fault lines of a capitalist modernity.

The narrative resolution of the novel is charted out in terms of the protagonist's systematic progression from traumatized victim to an active agent of retribution. There is a marked change in tone from Veronica's excruciating attempts to recollect the fragmented past to her eventual bold declaration that Liam's story needs to be told (223). Finally, storytelling itself becomes an act of radical self-assertion. It functions as a medium of establishing justice against the historical crime of child sexual abuse. Contextualizing storytelling in the turbulent political scenario of Northern Irish society, scholars Claire Hackett and Bill Rolston argue that, "telling is the re-booting of the humanity lost in the trauma, the correcting of the malfunctioning that set in. Testimony is not just a simple exercise, 'allowing victims to get things off their chest.' It is at the core of constructing interpretation and memory" (360). The Gathering incorporates the transformative potential of storytelling to reassert the humanity of the protagonist Veronica. In 
the process it also restores the humanity of the victim Liam, since the act of abuse is based on the fundamental violation of his subjectivity.

There is a marked change in tone when the narrator claims with bold authority: "I know, as I write about these things ... that they require me to deal in facts. It is time to put an end to the shifting stories and the waking dreams. It is time to call an end to romance" (142). Besides the shift from one narrative form (romance) to another (facts), these prophetic words invoke the narrator's own journey of self-recovery. The act of writing itself does not recover the truth, but it does indicate Veronica's transition from an unreliable narrator to one who is willing to confront the conditions under which narration takes place. In other words, Veronica's implicit association of writing with "facts" suggests a conscious desire to reclaim her personhood as a narrator whose story demands and deserves to be acknowledged.

Parallel to the main narrative articulated by Veronica as a testimonial to her brother's sexual abuse runs the narrative of her own recovery. The novel balances the two stories so that the former is explicit, the latter implicit. There is a marked change in the protagonist once the family history, including the traumatic abuse, has been communicated. She focuses on the ongoing preparations to bring Liam's dead body home and organize a funeral for him. This is an important sub-plot which also brings together her extended family - her mother and all her siblings, "Bea, Ernest, Ita, Mossie, Kitty, maybe Alice and definitely the twins Ivor and Jem” (187). Veronica's aging mother still lives in the family house in Broadstone but her own siblings live and work in different parts of the world: "They will thunder in overhead, in the huge bellies of planes. Ivor from Berlin, and Jem from London, Ita from Tucson, the mysterious Alice from God knows where. Maybe even Father Ernest in a stripy ethnic hat, in from Lima via Amsterdam" (187). Having built their lives and careers overseas, they too reflect the success 
story of globalization's outward flows. By reaching out to them, Veronica is able to articulate the full implications of Liam's fate as well as her own, so deeply intertwined with his.

As Veronica ponders the implications of Liam's suicide she realizes, only too clearly, the profound paradox of her life and that of her siblings as individuals who have acquired a degree of middle-class success. Her siblings, who otherwise have marginal presence in the novel, represent the Celtic Tiger success story made possible by the movement of populations across national borders. Such movement, inflected by the dynamic interplay of the local and the global, has enabled them to disengage from the particular history that binds them to Broadstone, and more generally to Ireland. Liam on the other hand, who lived and died in Brighton, a suburb of England, embodies a different form of border crossing, that of the indigent worker, which is deeply embedded in the "other" narrative of Ireland's struggle to find an economic foothold in the postcolonial world.

As Veronica waits for Liam's body, she wanders around town, shopping for presents for her family. The apparent normalcy of this action however, is ruptured by thoughts about her dead brother:

I find myself crying on the escalator in Brown Thomas, which is only a shop. And the fact that makes me cry is that there is nothing here that I cannot buy. I can buy bedlinen, or I can buy a bed. I can buy posh jeans for the girls or a Miu Miu jacket for myself...I can buy the plastic Brabantia storage jars that I am now staring at on the third floor, that I actually might need for pasta and rice and lentils and pumpkin seeds and all sorts of dry goods ... I try to count. Should I get one for the polenta ... the jars are half-price ... (189).

This is a particularly suggestive passage that begins with Veronica grieving over Liam but ends with her trying to make a purchase. Such a change is not merely accidental but a reflection on the 
inevitable incursion of mundane consumption into the deepest realms of the human consciousness. The impersonal, uniform and artificial space of the shop is at once familiar and alienating. The branded commodities, the "Miu Miu jacket," the "Brabantia storage jars," etc. help Veronica forget, albeit temporarily, the grief of loss. At the same time, it bestows a certain objectivity of perspective that allows her to consider how far Liam always was from the middleclass existence that such a space endorses and exemplifies.

The night of Liam's wake brings back sad memories for Veronica as she roams the old family home trying to evaluate her memories in their original context. Her mother, Mrs. Hegarty, informs her that Lamb Nugent was in fact Ada's landlord, and Veronica comes to realize the considerable economic power that he, Nugent, had over Ada. Veronica no longer thinks of Ada and Nugent as a romantic couple. A different narrative begins to emerge as Veronica deconstructs the image of the abuse that she had preserved in her memory: "The abuse happened in the garage, among the cars and bits of engine that Liam loved. And Nugent was horrible to my brother in ordinary ways, too, out there. He had his sadisms I am sure, and his methods" (223). Veronica takes an important step towards redressing this injustice: "I owe it to Liam to make things clear - what happened and what did not happen in Broadstone" (223). The coming together of the Hegarty family, in fact, marks the beginning of this process of clarification, thereby posing a turning point in the narrative.

If the scattered family in The Gathering exemplifies, very prominently, the disruptive effects of globalization, their return acquires a symbolic significance precisely because they, unlike Liam, have managed to successfully disengage from their past. The narrative foregrounds the difference between the properly socialized Hegartys -- and Liam, who dies -- to comment on the different scales of human alienation in the age of globalization. It is this difference that gives 
the novel its political and historical valence. Liam's story in combination with those of his brothers and sisters represent Ireland's uneven development during the Celtic Tiger period. While the other siblings have moved on with their lives, Liam has had to live out the failures, injustices and crimes of the past. His suicide stems from his sexual abuse, while he is also simultaneously a victim of neoliberal labor conditions. He is able to escape his family but his new life abroad fails to provide him any solace. Paradoxically, it is the buying and selling of property in the increased capital flows of the Celtic Tiger moment that uncovers historical incidents of abuse such as Liam's. As an upper-middle class woman, Veronica too finds increasing and better options to "choose" from in shopping for commodities. She can, literally, buy her way into therapeutic release. But she loses her economic autonomy as well as her role as mother and wife. Such are contradictory effects of a globalized modernity on her life.

Veronica's reflections on her family history testify to her progress from trauma victim to a self-aware individual. Veronica no longer internalizes her guilt but situates it within a familial paradigm of collective aspiration: “none of us is straight. It is not that the Hegartys don't know what they want, [but] it is that they don't know how to want. Something about their wanting went catastrophically astray" (223, original emphasis). The prophetic declaration, emphasized in the definitive "wanting," sums up Veronica's desire to confront the injustices of the past. At this point of the narrative she speaks with much more clarity, propelled by the realization that "I owe it to Liam to make things clear" (223). Collecting her memories of the past Veronica is able to assert that the abuse was in fact an ongoing reality for the child Liam. Lamb Nugent had "his sadisms, I am sure, and his methods" (223). The suggestive declaration "I am sure", contrasts with Veronica's uncertainty at the outset of the narrative. Once the exact circumstances of the abuse become clear, Veronica is able to recast her purposes towards the remedy of this injustice. 
The novel's ending posits neither a simplistic overcoming of crisis nor a flight away from reality. Instead Veronica (and Enright) indicates that the first step towards recovery lies in confronting her own thoughts and desires. It is necessary to embrace the life she has -- critically: Veronica says, "I do not want a different destiny from the one that has brought me here. I do not want a different life. I just want to live it, that's all" (260). This is a markedly different and more assertive voice from the beginning of the novel. The change of tone indicates that engaging with and knowing the truth bestows a clarity of vision, and gives voice to what has remained repressed in the narrator's memory. But this can also be read as the reclamation of the female subject as a transformed speaking agent who can, through her own efforts, recover a history that has been effectively sidelined by the dominant discourse.

\section{Conclusion}

As an emblematic postcolonial text, The Gathering challenges the discourse of unilateral - and unilinear -- development popularized during the Celtic Tiger years. The interplay between fact and fiction, and the private and the public provides an appropriate ideological context for the novel to interrogate the notion of a self-contained Irish history. Instead, the novel emphasizes a dialectical relation between the personal and the public, and the local and the world-historical. As a critique of the Celtic Tiger, The Gathering achieves two important functions. It re-instates the historically marginalized object, the abused child Liam through an active speaking subject, Veronica. Second, the narrative questions postcolonial nation formation through its strategic braiding of personal histories of neglect and abuse and a rapidly instituted, uneven capitalist development. It produces, in short, a counter-history. 
Similarly, The Gathering's interlinking of the fraught public discourse of the Celtic Tiger and the subject-in- trauma illuminates the violated body as a key if unacknowledged register of deep, structural fractures. In the context of Irish literature and culture, where religious and social norms of sexuality have situated "the corporeal" at "the crux of conflict" (Cahill 2), such fractures resurface in the process of literary narration. In The Gathering this conflict is configured in Veronica's recovery of the obfuscated history of the violated body, a process that effectively disrupts the celebratory mood of the Celtic Tiger years. Veronica and Liam, as both subject and object, exemplify this violent process of silencing. The novel emphasizes the unmistakable complicity of material forces in the exclusion of certain bodies and the hypervisibility of certain others; this takes place according to the needs of an inscrutable system -globalizing capital, which seeks to create a false image of the universal realization of democracy, choice and individual freedom.

One of the most prominent critics of the Celtic Tiger, Irish Times columnist Fintan O’Toole has trenchantly described these years as having, a "Hollywood style narrative arc." The discursive thrust is one of progress, "a tale of misery, struggle, [followed by] transformation and triumph. And it came with a ready-made moral: neo-liberal globalization works." (11) Similarly Donald E. Morse charts how the Celtic Tiger promoted a culture of greed and ostentatious display, documenting specific instances of top-level bureaucratic money laundering. According to Morse, the Irish public made some money but "plunged deeper into debt": ultimately, it was "the developers and bankers who made millions and paid little or nothing into the public treasury" (243). The Gathering not only refuses such easy closure, it underscores the human costs of such accumulative practices, through Liam, but also through Veronica and her financier husband represent the putative beneficiaries. It reinscribes the paradoxes of Ireland's financial 
success story as precisely that; a "story" that is validated by excluding marginalized subjects such as Liam.

In the short penultimate chapter Veronica remembers Ada, who is long dead, once more. She remembers Ada saying that, "people ... do not change, they are merely revealed" (252). Veronica recalls that Nugent too is dead from cerebral aneurysm - a highly symbolic death caused essentially by a diseased mind. Recalling Ada and Nugent offers a figurative closure to the novel, as Veronica can finally stop constructing stories to come to terms with the past. This closure opens up, at the same time, myriad possibilities for the protagonist's future.

The scene at the Gatwick airport at the end of novel is significant in this regard. After a lengthy and emotionally charged family gathering, the narrator becomes calm and collected. She even picks up little gifts for her daughters, ready to re-embrace them as a mother. She "think[s] it [is] a great and quite victory to have them [her daughters] in the world." (257) Having reached the end of her story, Veronica sleeps for eight hours in her airport hotel room - an immediate sign of recovery from insomnia and trauma. She even considers the possibility of having another child, this time a boy, whose name she already knows (260). The artificial space of the airport foregrounds a necessary transition from the depths of the past to the present. The episode provides what the narrator describes as "extra time," which is the temporal gap between comingto-terms with past trauma and acclimatizing to the present. Every aspect of this transition is carefully weighed against the protagonist's past experiences: not just as a child witnessing a horrific sexual act, but also as a trauma victim confronting a difficult reality.

As the narrator waits at the airport lounge she becomes aware of the universal aspect of journeys, "I look at people at the people queuing at the till, and I wonder are they going home, or 
are they going far away from the people they love." (258) These reflections shed a new light on her own journey, that began with the "clean, white bones" (2) of repressed memories and ended with the acknowledgement that truth entails, "pulsing back and forth along ghostly veins that wrap the world in a skein of blood". This is an acceptance of the final journey that Veronica needs to undertake, one that will take her home back to her family, waiting for her in Dublin.

To offer some summary and final remarks: the diversity of the literature produced at the margins of the dominant culture, in terms of theme as well as form, makes it necessary to outline their relationship with globalization. In current critical discourse, this relationship is increasingly defined as change from economic backwardness to modernization and progress. Mariano Siskind, for instance, postulates that, "the peripheries of the world have an intense desire for socio-political and cultural modernization”. Siskind holds that is a desire represented in and by novels, to the extent that globalization becomes "both the condition of possibility and impossibility of modernity (and of novelistic difference) in the margins of the universal" (342). Such a formulation, however, falls into the danger of oversimplifying both "desire" and "modernity," and of ignoring the myriad modes of engagement found in peripheral literatures that critique the very categories by which such terms are understood and applied.

Contemporary literature, I have argued with reference to Enright's novel, represents globalization not as a condition of modernity, but as a symptom of late-modern, uneven capitalist development, one that entails economic expansion without the transformational, and supposedly democratizing role of global bourgeois culture. One of the dominant trends of contemporary globalization as a process has been to subordinate human desire to market forces, so that both "desire" and "modernity," as much as the desire for modernity, is mediated by the logic of capital. As such, the transformatory potential of modernity as a philosophy, and idea of rational 
self-formation, is replaced by the strictly consumerist scramble for commodity acquisition and upward mobility. Fiction then becomes a means of both articulating the contradictory desires fostered by globalization, and a means of resistance. In globalization-era fiction, the themes of migration, displacement, the family and the nation become dynamic categories, which must be understood dialectically, in relation to the particular interaction of global capital with specific local geo-political contexts. The role of literature must encompass a nuanced and historically grounded engagement with neoliberal globalization so that its many fault lines may be rendered visible.

The Gathering posits an ending that effectively challenges the reader's imagination. The narrative ends when the final destination is about to be reached, at least in the protagonist's mind: "I have been falling into my own life, for months. And I am about to hit it now" (261). Here, too, the narrative describes concrete action, as Veronica boards the plane that will take her home. Yet her use of the word "falling" to describe this process leaves her feelings ambiguous and open to interpretation. This disjuncture, in turn, reflects the alienation that ensues even when the progression of events has stalled, since it is an almost forced closure based on the acceptance of a harsh and tragic reality that remains to the end unaltered and un-redressed. The novel seems to achieve the sense of an ending (to borrow Frank Kermode's beautiful phrase) caught at the crossroads of an incomplete and fractured globalized modernity, where the residues of history invariably impinge upon the present and future of life in the postcolonial periphery. 


\section{CONCLUSION}

"But there's a way of life that is its own witness: put the kettle on, shut the blind. Home is a sleeping child, an open mind"

“Domestic Interior,” by Eavan Boland

The concept of domesticity described so articulately in Boland's poem, invokes myriad responses. Whether it is configured as "house," "nation," or in the more abstract sense of "home" or "imagined community" (Anderson 1983), the concept carries an almost sacrosanct implication. It codifies, mandates and evokes very particular forms of identification with lived and built environment; a place of refuge as well as confinement. When the home, with all its symbolic and emotional weight, finds expression in literature, such as in the domestic novel, it is often implicitly allegorical in function. It becomes a site of multifaceted stories: encompassing complex family sagas, evoking historical memories and events, and - through a glimpse of the most private experiences - revealing the entrenched fractures of public social life.

Literary articulations of the domestic in women's writing from Ireland and India highlight the effects of a "coerced insertion into the political, economic and cultural machinations of capitalist modernity" (Flannery 5). Irrespective of the specific trajectories of the two nations, the shared experience of colonial-capitalist coercion manifests itself in common, in representations of domestic space. Situating India with Ireland in a comparative frame, in fact, sheds new light on literary fiction that are categorized variously as Anglophone literature, vernacular literature, global fiction etc. The trope of the domestic provides a common ground, as 
I have tried to show in the previous pages, on which the development of specific national literary traditions, and their thematic and formal tenets, may be particularized.

One however needs to be mindful, of the distinct concerns of an Irish or Indian national literary tradition when invoking the category of domestic fiction. Homes, after all, are private empires; each has its belief systems, ancient feuds, subjects and authority figures. To generate a comparison between the literatures of these two, geo-politically diverse nation-states demands an acknowledgement of their unique and distinct histories. What is common, across national and literary borders however, is the inherently exploitative (often violent) exercise of control political, familial and economic - over the social relations of domesticity. It is by examining the analogies between the Irish and Indian representations of domesticity, as well as the differences, that the imaginaries of home and belonging become visible in their full expressive form.

The literary works I explored bring together multiple variables - domestic fiction, feminist self-expression, nationalism, core-periphery and the world-system. These are not merely invoked as theoretical categories, but as inextricable aspects of lived reality that converge in the single work of fiction, in this case, the domestic novel. By analyzing different typologies of domestic fiction, I examined how each of these variables is inflected by historical time and space. It can be said in this respect that Irish and Indian domestic fiction are deeply interconnected - thematically as formally - as the aesthetic expression of the particular process of nation formation. The myriad ways in which domestic fiction engages with this process at critical junctures of history sheds light on the changing configurations of class, gender and nationalism in these moments. 
Elizabeth Bowen's The Last September (1928) and Molly Keane's Good Behavior (1981) capture, at very different moments of writing, the crisis of the inter-war years. Bowen and Keane illustrate a unique historical sensibility; instead of mourning or eulogizing the demise of the Anglo-Irish class that they come from, they narrate its historical self-destruction as well as the subsequent contestations over its memory. The engagement of these authors with literature and history is thus a progressive one; they are able to reflect and comment on the fraught process of Irish decolonization as a historical inevitability, while challenging the normative pieties of the dispensation that follows in the wake of the old order.

If architectural tropes form a crucial aspect of Big House fiction, in Bowen and Keane, Mahasweta Devi and Jennifer Johnston explore the challenges of self-formation with reference to youth. Devi's Mother of 1084 (1974) and Johnston's Shadows on Our Skin (1977) both belong to the same time frame - that of the 70's - and engage with the promises and complexities of revolutionary nationalism. These are periods of intense turmoil in India and in Northern Ireland. Devi and Johnston bring these events inwards, and deploy the political upheavals of this time to chart its determining influence on youthful subjectivity and interiority. Domestic space, in both novels, becomes a figure for the human struggle for autonomy. It elucidates the material and structural incongruities that prevent the successful formation of the individual. The trajectory of self-formation or self-cultivation in a moment of severe public outrage must turn inwards as an expression of fundamental alienation.

Reading Johnston and Devi's novels in a comparative frame, highlights a relatively neglected task of committed fiction: its ability to evoke empathy for the marginalized female subject. One of the ways their novels achieve this is by foregrounding the figure of the mother. It is a remarkable achievement on Johnston's part to illustrate through Mrs. Logan in Shadows, for 
example, the crisis of the working-class woman in the periphery. Mrs. Logan has to support her family through domestic and public labor. The novel's realism, critique, and disenchanting effects rely on her character. For Mrs. Logan there is no ideology, no politics that promises redemption; in fact active political participation of any kind is a distant dream. It is on the back of her relentless labor that the nationalist son can proclaim his "revolutionary" zeal.

In a related theme, Mahasweta Devi describes an upper-class woman Sujata, who attempts to understand the Naxalite ideology of her revolutionary son. Through her engagement with her son's politics, Sujata can take up the stance of "refusing" the conditions of her milieu. Both Shadows and Mother of 1084 thus uses the mother-son dynamic to launch a radical restructuring of the domestic, just as the Troubles and the Naxalite uprising were projected by the Indian and Irish state as internal or domestic security threats.

The last two chapters of this project, Kiran Desai’s The Inheritance of Loss (2006), and Anne Enright's The Gathering (2007), speak to the contemporary moment of transnationalism, of unregulated economic flows and their destructive impact on the family structure. Enright's novel is particularly important in this regard since it actively dismantles dominant projections of globalization as a success story; such as the claim advanced for Ireland as Celtic Tiger Ireland, its poster-child. Desai's novel, which came out within a few years of the India Shining campaign of 2004, critiques India's aspirations by drawing attention to those immigrants exiled from home, and the marginalized within the neoliberal dispensation.

Desai and Enright's novels share, unsurprisingly perhaps, several thematic overlap. These stories reveal the incongruity in the idea that globalization generates opportunities for economic and social mobility. Such opportunities invariably come with enormous human cost, oblivious to 
those held in its allure. Desai in particular, critiques the projection of India as an exemplary case of Third World self-assertion by illustrating that not all imaginaries that emanate from such a space are necessarily progressive. To subsume the internal differences and overlaps of Desai and Enright's works under the metropolitan rubric of "post-al" terms is thus inherently reductive; it obfuscates the fractures of neoliberal capitalism that may be represented through politically conscious fiction.

What connects the historically and geopolitically diverse fiction of Bowen and Keane, Johnston and Devi, Desai and Enright is perhaps their shared concern with human alienation as a constant aspect of historical change. The domestic provides a concrete site where such alienation begins. The relation of the individual, gendered protagonist, to the domestic realm exemplifies this alienation at a microcosmic level. Narratives of globalization such as Desai's The Inheritance and Enright's The Gathering are particularly insightful on this account. By breaking down the boundaries of nationality, ethnicity, and historical time, they configure modern alienation as a lived reality in the periphery. In doing so these narratives indicate the urgency, as Benita Parry says, of "discriminations ... other than those entrenched in the existing criteria of both mainstream and marginalized literary discussion" (2009: 27).

Recent postcolonial feminist scholarship has emphasized the intricate overlap between the public and the private to reorient critical attention to domestic fiction - a field historically relegated as secondary in canons dominated by male authors (Andrade 2011). Such a critical return to the domestic reinstates it as a site of struggle for mutually contesting visions of nationhood and subjective belonging. It is noteworthy that such relegation has been an almost ubiquitous phenomenon in national and global literary traditions. It is not surprising, therefore, 
that women's writing, particularly from peripheral geo-political contexts have provided some of the most rigorously combative perspectives on the paradoxes of modern nation formation.

The concepts of core and periphery are especially useful in understanding the ideological underpinnings of such radically subversive perspectives. As the novels of Bowen, Keane, Johnston, Devi, Desai and Enright elucidate, these concepts may be mobilized to illustrate multiple configurations of the peripheral. In Johnston's Shadows for example, the Catholic tenements of Derry posit uniquely peripheral spaces in its own right, despite the fact they are geographically a part of the larger periphery of Northern Ireland. Similarly, in Desai's The Inheritance, the indigenous populations of India's North East, namely the Gurkhas, Lepchas and Bhutias form a periphery of their own, in their struggle against the oppressive, coercive machinations of the Indian state, itself a peripheral entity within the capitalist world-system. These situations are distinctive and they highlight, in no uncertain terms, the inadequacies of the categories of West/non-West and First/Third World.

It is now a commonplace to argue that women writers have historically situated their narratives in the domestic realm (Andrade 2011, Ingman 2007). It is no surprise that domestic fiction, in its varied typologies, has been a site where women writers have predominated, both in Ireland and India. Still, what is often neglected by metropolitan discourse is the historical context behind such predominance. Women writers in any given context, but more so in the peripheries form a relatively privileged group by virtue of their education, literary talents and certain degree of economic freedom. They are thus uniquely situated to illuminate and comment on the particular modes of exploitation and exclusion upon which the privileged construct their ideal vision of social cohesion. Women writers emphasize the position of less acknowledged subjects of the home - unmarried daughters, professional service-class women, domestic helps, 
dependent relatives etc. These characters problematize the privileging of the male heir, the sons of the house as the normative, universal subjects. Often these stories demand to be told, and offer much more interesting narratives, than those mandated by privileged gender, class and social pedigree.

Configurations of domesticity change in different historical junctures. In fact the metaphorical march of history, unearthing the ruptured unity of time and place, manifests itself most acutely in the internal dynamics of the family form. The birth of children, the achievement of maturity, marriages and separations, the passing down of a particular legacy - all combine in the domestic novel to reveal the unevenness of time and space in the periphery. The temporal memory of the familial or the domestic is thus often counterpoised to that of the nation. The latter has lost much of its ideological and emotional power with the world wide crisis of anticolonial decolonization movements, the struggle to uphold collective action, social justice and the ideals of social welfare under the capitalist hegemony of exploitative expansion. The family form however often actively mirrors these contradictions and has therefore served as an enduring subject of literary and cultural production.

The consolidation of majoritarian nationalism in current phases of neoliberal globalization has implied the structural withdrawal of the welfare functions and organs of the nation-state. Concomitant to such developments is a parallel problem - the co-opting of antiimperialist democratic movements globally, by dominant regimes, through a "reactionary use of the past and history" (Bannerji 1). What Jack Forbes called "the wetiko disease of exploitation, imperialism and terrorism" (1992), to describe the pathology of land-grab and slaughter in the New World, is exploding symptomatically all over the globe once more, in the guise of corporate globalization, displacing populations, breaking social and familial formations - decisively 
altering definitions of home and belonging (Moghadam 2005; Boehmer 2005). There is an urgent need, in other words, of recovering narratives that emphasize the material incongruities caused by global capitalism.

This project has attempted to outline, through its study of women's domestic fiction, the value of literature itself as site of change. It has consciously re-negotiated the boundaries imposed by such concepts as First/Third World, West/non-West, developed/developing. By facilitating a conversation between domestic fiction from Ireland and India, it has attempted to gesture towards the immense possibilities of a truly dialectical, internationalist paradigm of literary analysis. Such an approach, I argue, can transform how metropolitan and peripheral audiences read and understand women's fiction, how to make its stories their own in order to generate progressive, non-monolithic modes of thought and expression. It is only by reinstating the human subject, as these stories do, as an agent of social change, that fiction can achieve its purpose in the globalizing world. 


\section{BIBLIOGRAPHY}

Adorno, Theodor W. Minima Moralia: Reflections From Damaged Life. Trans. E.F.N. Jephcott. New York: Verso, 2006.

Ahmad, Aijaz. "Jameson's Rhetoric of Otherness and the 'National Allegory."” Social Text 17 (1987): 3-25.

Ahmad, Aijaz. In Theory: Nations, Classes, Literatures. London and New York: Verso, 1992.

Amin, Samir and Patrick Camiller. Beyond US Hegemony: Assessing the Prospects for a Multipolar World. London: Zed Books, 2013.

Anderson, Benedict. Imagined Communities: Reflections on the Origin and Spread of Nationalism. London and New York: Verso, 1991.

Andrade, Susan. The Nation Writ Small: African Fictions and Feminisms, 1958-1988. Durham: Duke University Press, 2011.

Appadurai, Arjun. Modernity at Large: Cultural Dimensions of Globalization. Minneapolis: University of Minnesota Press, 1996.

Apter, Emily. Against World literature: On the Politics of Untranslatability. New York: Verso, 2014.

Armstrong, Nancy. Desire and Domestic Fiction: A Political History of the Novel. Oxford and New York: Oxford University Press, 1987.

Bannerji, Himani. The Dark Side of the Nation: Essays on Multiculturalism, Nationalism and Gender. Toronto: Canadian Scholars' Press Inc., 2000.

Benjamin, Walter. The Origin of German Tragic Drama. New York and London: Verso, 1977. 
Beverly, John. Testimonio: On the Politics of Truth. Minneapolis: University of Minnesota Press, 2004.

Bhabha, Homi. "Of Mimicry and Man: The Ambivalence of Colonial Discourse." Discipleship: A Special Issue on Psychoanalysis 28 (1984): 125-133.

Bhabha, Homi. Ed. Nation and Narration. New York: Routledge, 1990.

Bhattacharya, Dipankar. "Trail Blazed by Naxalbari Uprising." Economic and Political Weekly 41.50 (2006): 5191 - 5194.

Boehmer, Elleke. Stories of Women: Gender and Narrative in the Postcolonial Nation. Manchester: University of Manchester Press, 2005.

Boes, Tobias. "Apprenticeship of the Novel: The Bildungsroman and the Invention of History, CA. 1770 - 1820" Comparative Literature Studies 45.3 (2008): 269 - 288.

Boland, Eavan. "Domestic Interior." in Outside History: Selected Poems, 1980-1990. New York: W.W Norton \& Company, 1991. 151-152.

Booth, Wayne C. The Rhetoric of Fiction. Chicago: University of Chicago Press, 1961.

Bowen, Elizabeth. The Last September. New York: Random House, 1998.

Brass, Paul R. The Politics of India Since Independence. New York: Cambridge University Press, 2001.

Brennan, Timothy. Wars of Position: The Cultural Politics of Left and Right. New York: Columbia Press, 2006.

Brouillette, Sarah. Postcolonial Writers in the Global Literary Marketplace. New York: Palgrave Macmillan, 2007.

Brown, Terence. Ireland: A Social and Cultural History, 1922 to the Present. Ithaca: Cornell University Press, 1985. 
Burton, Antoinette. Dwelling in the Archive: Women Writing House, Home, and History in Late Colonial India. New York: Oxford University Press, 2003.

Cahalan, James M. Double Visions: Women and Men in Modern and Contemporary Irish Fiction. Syracuse: Syracuse University Press, 1999.

Cahill, Susan. Irish Literature in the Celtic Tiger Years 1990 to 2008: Gender, Bodies, Memory. New York: Continuum International Publishing Group, 2011.

Caruth, Cathy. Unclaimed Experience: Trauma, Narrative and History. Baltimore: John Hopkins University Press, 1996.

Casanova, Pascale. The World Republic of Letters. Trans. M.B. DeBevoise. Cambridge, MA: Harvard University Press, 2004.

Chatterjee, Partha. The Nation and Its Fragments. Princeton: Princeton University Press, 1993.

Cleary, Joseph. "Misplaced Ideas? Locating and Dislocating Ireland in Colonial and Postcolonial Studies.” Marxism, Modernity and Postcolonial Studies. Ed. Crystal Bartolovich and Neil Lazarus. Cambridge: Cambridge University Press, 2002.

Cleary, Joseph. Literature, Partition, and the Nation State: Culture and Conflict in Ireland, Israel, and Palestine. Cambridge: Cambridge University Press, 2002.

Cleary, Joseph. Outrageous Fortune: Capital and Culture in Modern Ireland. Dublin: Field Day Press, 2007.

Dasgupta, Biplab. "Beyond Naxalbari.” Economic and Political Weekly 41.29 (2006): 3159 3163.

Dasgupta, Rana. "A New Bend in the River: The Future of the Indian Novel in English." The National. Vol. 26. 2010. 
Dean, Tanya. "Staging Hibernia: Female Allegories of Ireland in Cathleen Ní Houlihan and Dawn.” Theatre History Studies 33.1 (2014): 71-82.

Deane, Seamus. Strange Country: Modernity and Nationhood in Irish Writing since 1790. Oxford and New York: Oxford University Press, 1996.

Deckard, Sharae, Neil Lazarus et al. Combined and Uneven Development: Towards a New Theory of World-Literature. Liverpool: Liverpool University Press, 2015.

Dell'Amico, Carol. “Anne Enright's The Gathering: Trauma, Testimony, Memory.” New Hibernia Review 14.3 (2010): 59 - 73.

Desai, Kiran. The Inheritance of Loss. New Delhi: Penguin Books, 2006.

Devi, Mahasweta. Mother of 1084. Trans. Samik Bandopadhyay. Calcutta: Seagull, 1997.

Dirlik, Arif. "Specters of the Third World: Global Modernity and the End of the Three Worlds." Third World Quarterly 25.1(2004): 131-148.

Dirlik, Arif. "The Postcolonial Aura: Third World Criticism in the Age of Global Capitalism." Critical Inquiry 20.2 (1994): 328-356.

Dixon, Paul. Northern Ireland: The Politics of War and Peace. New York: Palgrave, 2001.

Donnelly, James S. "Big House Burnings in County Cork During the Irish Revolution, 1920-21. Eire-Ireland Volume 47.3-4 (2012): 141-197.

Donner, Henrike. "Radical Masculinity: Morality, Sociality and Relationships Through Recollections of Naxalite Activists." Dialectical Anthropology 33.3-4 (2009): 327-343.

Dooley, Terence. The Decline of the Big House in Ireland: A Study of Irish Landed Families, 1860-1960. Dublin and New York: Wolfhound Press, 2001.

Ellmann, Maud. Elizabeth Bowen: The Shadow Across the Page. Edinburgh: Edinburgh University Press, 2003. 
Erikson, Kai. "Notes on Trauma and Community." in Trauma: Explorations in Memory. Ed. Cathy Caruth, Georges Bataille. Baltimore: John Hopkins University Press, 1995. 183 99.

Esty, Jed. Unseasonable Youth: Modernism, Colonialism, and the Fiction of Development. Oxford and New York: Oxford University Press, 2012.

Flannery, Eoin. Ireland and Postcolonial Studies: Theory, Discourse, Utopia. New York: Palgrave Macmillan, 2009.

Forbes, Jack D. Columbus and Other Cannibals: The Wetiko Disease of Exploitation, Imperialism and Terrorism. New York: Seven Stories Press, 1992.

Foster, John Wilson. The Cambridge Companion to the Irish Novel. Cambridge: Cambridge University Press, 2006.

Gardam, Sarah “"Default[ing] to the Oldest Scar': A Psychoanalytic Investigation of Subjectivity in Anne Enright's The Gathering.” Etudes Irlandaises 34.1 (2009): 99 - 112.

Genet, Jacqueline. Ed. The Big House in Ireland: Reality and Representation. Kerry: Brandon Book Publishers, 1991.

Gibbons, Luke. Transformations in Irish Culture. Cork: University of Cork Press, 1996.

Gikandi, Simon. "Globalization and the Claims of Postcoloniality.” The South Atlantic Quarterly 100.3 (2001): 627-658.

Gikandi, Simon. "Globalization and the Claims of Postcoloniality." The South Atlantic Quarterly 100.3 (2001): 627-658.

Gopal, Priyamvada. The Indian English Novel: Nation, History, and Narration. New York: Oxford University Press, 2009. 
Grubgeld, Elizabeth. Anglo-Irish Autobiography: Class, Gender, and the Forms of Narrative. Syracuse: Syracuse University Press, 2004.

Hackett, Claire, and Bill Rolston. "The Burden of Memory: Victims, Storytelling and Resistance in Northern Ireland." Memory Studies 2.3 (2009): 355 - 376.

Harper, Margaret Mills. "Flesh and Bones: Anne Enright's The Gathering." South Carolina Review 43.1 (2011): 74 - 89.

Harte, Liam. "Mourning Remains Unresolved: Anne Enright's The Gathering (2007).” In Reading the Contemporary Irish Novel 1987-2007. Oxford: Wiley-Blackwell, 2013. p. 217-241.

Henke, Suzette A., and Elaine Unkeless. Women in Joyce. Chicago: University of Illinois Press, 1982.

Hobsbawm, Eric and Terence Ranger eds. The Invention of Tradition. London: Canto, 1983.

Howe, Stephen. Ireland and Empire: Colonial Legacies in Irish History. Oxford: Oxford University Press, 2000.

Huggan, Graham. The Postcolonial Exotic: Marketing the Margins. New York: Routledge, 2001.

Ingelbien, Raphael. “Gothic Genealogies: Dracula, Bowen's Court, and Anglo-Irish Psychology.” ELH 70.4 (2003): 1089-1105.

Ingman, Heather. Twentieth-Century Fiction by Irish Women: Nation and Gender. Aldershot: Ashgate Publishing, Ltd., 2007.

Jackson, Elizabeth. Feminism and Contemporary Indian Women's Writing. London: Palgrave Macmillan, 2010.

Jameson, Frederick. “Periodizing the 60's." Social Text 9 (1984): 178-209. 
Jameson, Fredric. "Modernism and Imperialism." In Jameson, Terry Eagleton and Edward Said, Nationalism, Colonialism and Literature. Minneapolis: University of Minnesota Press, 1980, 43-68.

Jani, Pranav. Decentering Rushdie: Cosmopolitanism and the Indian Novel In English. Columbus: Ohio State University Press, 2010.

Johnson, Nuala C. "Framing the Past: Time, Space and the Politics of Heritage Tourism in Ireland." Political Geography 18.2 (1999): 187-207.

Johnston, Jennifer. Shadows on Our Skin (New York: Doubleday \& Company, 1978).

Jordan, Heather Bryant. “A Bequest of her Own: The Reinvention of Elizabeth Bowen” New Hibernia Review 12.2 (2008): 46-62.

Jordan, Justine. "A New Irish Literary Boom: the Post-crash Stars of Fiction" www.theguardian.com. 17 October 2015. Web. Accessed 28 January 2017.

Kang, Liu. "Mixed Style in Lu Ling's Novel Children of the Rich: Family Chronicle and Bildungsroman." Modern Chinese Literature 7.1(1993): 61- 87.

Keane, Molly. Good Behavior. London: Virago Press, 1981.

Kiberd, Declan. Inventing Ireland. Cambridge, Massachusetts: Harvard University Press, 1996. Killeen, Jarlath. The Emergence of Irish Gothic Fiction: History, Origins, Theories. Edinburgh: Edinburgh University Press, 2014.

Kreilkamp, Vera. “The Persistent Pattern: Molly Keane's Recent Big House Fiction.” The Massachusetts Review 28.3 (1987): 453-460.

Kreilkamp, Vera. The Anglo-Irish Novel and the Big House. Syracuse: Syracuse University Press, 1998. 
Krishnaswamy, Revathi and John C. Hawley. Eds. The Postcolonial and the Global. Minneapolis: University of Minnesota Press, 2007.

Krishnaswamy, Revathy. "Postcolonial and Globalization Studies: Connections, Conflicts, Complicities." The Postcolonial and the Global. Eds. Revathy Krishnaswamy and John C. Hawley. Minneapolis: University of Minnesota Press, 2007.

Lacina, Bethany. "The Problem of Political Stability in Northeast India: Local Ethnic Autocracy and the Rule of Law." Asian Survey 49.6 (2009): 998-1020.

Lassner Phyllis and Paula Dergider. "Domestic Gothic, the Global Primitive, and Gender Relations in Elizabeth Bowen's The Last September and The House in Paris". In Maria McGarrity and Claire Culleton eds. Irish Modernism and the Global Primitive. New York: Palgrave Macmillan, 2009, 195-214.

Lazarus, Neil and Crystal Bartolovich. Eds. Marxism, Modernity and Postcolonial Studies. Cambridge: Cambridge University Press, 2002.

Lazarus, Neil. The Postcolonial Unconscious. Cambridge: Cambridge University Press, 2011. Lecaros, Cecilia Wadsö. The Victorian Governess Novel. Lund: Lund University Press, 2001.

Lee, Alfred McClung. "Imperialism, Class and Northern Ireland's Civil War." Crime and Social Justice 8 (1977): 46 -52.

Lennon, Joseph. Irish Orientalism: A Literary and Intellectual History. Syracuse: Syracuse University Press, 2004.

Lloyd, David. "Regarding Ireland in a Post-colonial Frame.” Cultural Studies 15.1 (2001): 12 32.

Lloyd, David. Anomalous States: Irish Writing and the Postcolonial Moment. Durham: Duke University Press, 1993. 
Lloyd, David. Irish Times: Temporalities of Irish Modernity. Dublin: Field Day Press, 2008.

Loomba, Ania, Suvir Kaul et al. Eds. Postcolonial Studies and Beyond. Durham: Duke University Press, 2005.

Lyall, Sarah. “Anne Enright Wins Man-Booker Prize.” New York Times, Oct. 17, 2007. Web. Accessed June 25, 2016.

Lynch, Rachael Jane. “The Crumbling Fortress: Molly Keane's Comedies of Anglo-Irish Manners." In Theresa O'Connor Ed. The Comic Tradition in Irish Women Writers. Gainesville: University of Florida Press, 1996, 73-98.

Magennis, Caroline. Sons of Ulster: Masculinities in the Contemporary Northern Irish Novel. New York: Peter Lang, 2010.

Mane, Tejaswini Kiran and P. V. Ghorpade. "Representation of Cultural Difference in Kiran Desai's The Inheritance of Loss." The Criterion 3.4 (December 2012): 1-5.

Marx, Karl. Capital Volume 1: A Critique of Political Economy. New York: International Publishers, 1967.

Masterson, John. “Travel and/as Travail: Diasporic Dislocations in Abdulrazak Gurnah's By the Sea and Kiran Desai's The Inheritance of Loss." The Journal of Commonwealth Literature 45.3 (2010): 409-427.

Mathur, Om Prakash. Indira Gandhi and the Emergency as Viewed in the Indian Novel. New Delhi: Sarup and Sons, 2004.

McClintock, Anne. "Family Feuds: Gender, Nationalism and the Family." Feminist Review 44 (1993): 61-80.

McCormack, W.J. Dissolute Characters: Irish Literary History Through Balzac, Sheridan Le Fanu, Yeats and Bowen. Manchester and New York: Manchester University Press, 1993. 
McKittrick, David, and David McVea. Making Sense of the Troubles: The Story of the Conflict in Northern Ireland. Chicago: New Amsterdam Books, 2002.

Meaney, Geraldine. Sex and Nation: Women in Irish Culture and Politics. Dublin: Attic Press, 1991.

Meyer, Sara-Duana. “Of Win and Loss: Kiran Desai’s Global Storytelling.” Post-Liberalization Indian Novels in English: Politics of Global Reception and Awards. Ed. Aysha Iqbal Viswamohan. London: Anthem, 2014, 167-184.

Mezei, Kathy and Chiara Briganti. "Reading the House: A Literary Perspective.” Signs 27.3 (Spring 2002): 837-846.

Moghadam, Valentine. Globalization and Social Movements: Islamism, Feminism and the Global Justice Movement. Maryland: Rowman and Littlefield Publishers, 2013.

Moloney, Caitriona, and Helen Thompson. Eds. Irish Writers Speak Out: Voices from the Field (Syracuse: Syracuse University Press, 2003).

Moretti, Franco. “Conjectures in World Literature.” New Left Review. 1 (Jan-Feb) 2000: 54-68.

Moretti, Franco. "From The Way of the World: The Bildungsroman in European Culture." In Theory of the Novel: A Historical Approach. Ed. Michael McKeon. Baltimore: John Hopkins University Press, 2000.

Morse, Donald E. "The Economics of Utter Idiocy: The Rise and Demise of the Celtic Tiger." Hungarian Journal of English and American Studies (HJEAS) (2010): 243 - 256.

Moseley, Merritt. “Tidy and Untidy Novels: The Booker Prizes 2006 - 2007.” The Sewanee Review 116.2 (2008): 289 - 303.

Mukhopadhyay, Ashoke Kumar. "Through the eyes of the Police: Naxalites in Calcutta in the 1970’s." Economic and Political Weekly 41.29 (2006): 3227 - 3233. 
Nayak, Anoop. Race, Place and Globalization: Youth Cultures in a Changing World. Oxford: Berg Publishers, 2004.

Nordius, Janina. “A Tale of Other Places: Sophia Lee's The Recess and Colonial Gothic”. Studies in the Novel 34.2 (2002): 162-176.

O'Brien, Ellen L. "Anglo-Irish Abjection in the 'Very Nasty'; Big House Novels of Molly Keane.” LIT: Literature Interpretation Theory 10.1 (1999): 35-62.

O'Hearn, Denis. 'Globalization, 'New Tigers,' and the End of the Developmental State? The Case of the Celtic Tiger." Politics \& Society 28.1 (2000): 67 - 92.

O'Brien, Susie and Imre Szeman. "Introduction: The Globalization of Fiction/The Fiction of Globalization.” The South Atlantic Quarterly 100.3(2001): 603-626.

O’Neill, Ciaran. “The Irish Schoolboy Novel.” Eire-Ireland 44.1,2 (2009): 147-168.

O’Riain, Sean. “The Flexible Developmental State: Globalization, Information Technology and the 'Celtic Tiger'" Politics and Society 28.2 (2000): 157-193.

O'Toole, Fintan. Enough is Enough: How to Build a New Republic. London: Faber \& Faber, 2010.

Parry, Benita. “Aspects of Peripheral Modernism.” ARIEL 40.1 (2009): 27-55.

Parry, Benita. Postcolonial Studies: A Materialist Critique. New York: Routledge, 2004.

Prince, Simon. "The Global Revolt of 1968 and Northern Ireland." The Historical Journal 49.3 (2006): $851-875$.

Ramanathan, Geetha. Locating Gender in Modernism: The Outsider Female. New York: Routledge, 2012.

Redfield, Marc. Phantom Formations: Aesthetic Ideology and the Bildungsroman. Ithaca: Cornell University Press, 1996. 
Rolston, Bill. "Mothers, Whores and Villains: Images of Women in Novels of the Northern Ireland Conflict." Race and Class 31 (1989): 41-57.

Roy, Arundhati. Field Notes on Democracy: Listening to Grasshoppers. New York: Haymarket Books, 2009.

Roy, Srila. "The Everyday Life of the Revolution Gender, Violence and Memory." South Asia Research 27.2 (2007): 187-204.

Said, Edward. "Yeats and Decolonization". Nationalism, Colonialism, and Literature. Minneapolis: University of Minnesota Press, 1990.

San Juan Jr., Epifanio. "Postcolonialism and the Problematic of Uneven Development." Marxism, Modernity and Postcolonial Studies. Eds. Crystal Bartolovich and Neil Lazarus. Cambridge: Cambridge University Press, 2002.

San Juan Jr., Epifanio. Beyond Postcolonial Theory. New York: Palgrave Macmillan, 2008.

Sarkar, Tanika. Hindu Wife, Hindu Nation: Community, Religion, and Cultural Nationalism. Bloomington: Indiana University Press, 2001.

Schwall, Hedwig. “Anne Enright, The Gathering” Irish University Review 37.2 (2007): pp 594.

Schwarz, Roberto. Misplaced Ideas: Essays on Brazilian Culture. New York: Verso, 1992.

Shimray, U.A. "Socio-Political Unrest in the Region Called North-East India." Economic and Political Weekly 39.42 (2004): 16-22.

Silvestri, Michael. Ireland and India: Nationalism, Empire and Memory. New York: Palgrave Macmillan, 2009.

Sinha, Mrinalini. Specters of Mother India: the Global Restructuring of an Empire. Durham: Duke University Press, 2006. 
Siskind, Mariano. "The Globalization of the Novel and the Novelization of the Global. A Critique of World Literature." Comparative Literature 62.4 (2010): 336 - 360.

Sklair, Leslie. "Discourses of Globalization: A Transnational Capitalist Class Analysis." In The Postcolonial and the Global. Ed. Revathi Krishnaswamy and John C. Hawley. Minnesota: University of Minnesota Press, 2008.

Smith, James. Ireland's Magdalen Laundries and the Nation's Architecture of Containment. Indiana: University of Notre Dame Press, 2007.

Smyth, Gerry. "Irish National Identity after the Celtic Tiger." Estudios Irlandeses 7 (2012): 132 137.

Spivak, Gayatri C. “'Draupadi’ by Mahasveta Devi.” Critical Inquiry 8.2(1981): 381- 402.

Spivak, Gayatri C. Outside in the Teaching Machine. London and New York: Routledge, 1993.

St. Peter, Christine. Changing Ireland: Strategies in Contemporary Women's Fiction. London: Palgrave Macmillan, 2000.

Tariq, Gulam G. "The World of the 'Marginalized' in Mahasweta Devi’s Play Mother of 1084 The Criterion 2.2 (2011): 1-6.

Teekell, Anna. "Elizabeth Bowen and Language at War." New Hibernia Review15.3 (2011): 6179.

Tiwari, Shubha. "Writing as Social Service: The Literary Compass of Mahasweta Devi." Bologi October $26^{\text {th }} 2011$.Web. October $12^{\text {th }} 2015$.

Trotsky, Leon. The History of the Russian Revolution. Ann Arbor: University of Michigan Press, 1932.

Upstone, Sara. Spatial Politics in the Postcolonial Novel. New York: Routledge, 2009. 
Viswanathan, Gauri. "Ireland, India and the Politics of Internationalism." Journal of World History 15.1 (2004): 7-30.

Wallerstein, Immanuel Maurice. The Modern World-System I: Capitalist Agriculture and the Origins of the European World-Economy in the Sixteenth Century. Berkeley and Los Angeles: University of California Press, 2011.

Weekes, Ann Owens. Irish Women Writers: An Uncharted Tradition. Lexington: University of Kentucky Press, 1990.

Weekes, Anne Owens. "Ordinary Women: Themes in Contemporary Fiction by Irish Women.” Colby Quarterly 31.1 (1995): 88-99.

Wells, Susan. "Self-Cultivation, Political Reaction, and the Bildungsroman." Minnesota Review 13 (1979): 71-97.

Williams, Raymond. Marxism and Literature. Oxford: Oxford University Press, 1977.

Zerweck, Bruno. "Historicizing Unreliable Narration: Unreliability and Cultural Discourse in Narrative Fiction.” Style 35.1(2001): 151 - 176. 